\title{
Reducing The Democratic Deficit: ' Representation, DIVERSITY and THE Canadian JUdICIARY, OR TOWARDS A “TRIPLE P" JUdICIARY
}

\author{
RICHARD DEVLin," A. WAYNe MacKay"* \\ AND NATASHA KIM ${ }^{\cdots *}$
}

The authors review the current structures for judicial appointments in Canada and provide statistical information about the results of these mechanisms in respect to diversity of representation on the courts. They are also critical of the fairness and openness of judicial appointments processes.

After examining several variants of the dominant liberal view of law and of judges, the authors proffer and articulate a neo-realist theory of law and what they term a "bungee cord theory of judging." According to the former, law is inevitably a form of politics; according to the latter, judges are unavoidably political actors. In consequence, the judiciary is properly subject to democratic norms, including especially the norms of representation and of diversity. The authors then argue that, judged against those democratic norms, the present systems of judicial appointment (and the judiciary which it has put in place) suffers from what they term "a democratic deficit."

After a detailed examination of past attempts to reform this system, of arguments for and against a more democratic and representational approach to judicial selection, and possible models of judicial selection, the authors propose their own reform: the establishment by statute of Judicial Appointments Commissions. Such an approach might help cure the democratic deficit and produce what they dub a Triple-P judiciary, that is, one that is politically accountable, professionally qualified, and proportionally representative.
Les auteurs examinent la structure actuelle des nominations à la magistrature au Canada. Ils donnent aussi des statistiques sur les résultats de ces mécanismes en ce qui concerne la diversité de la représentation dans les tribunaux. De plus, ils questionnent lëquité et l'ouverture d'esprit des processus de nomination des juges.

Après avoir examiné plusieurs variantes de la vision libérale dominante du droit et de la magistrature, les auteurs présentent et énoncent une théorie néoréaliste du droit et de ce qu'ils appellent wune théorie de l'élastique d'appoint de la magistrature" ". D'une part le droit est inévitablement une forme de politique, et d'autre part les juges sont inévitablement des acteurs politiques. Ainsi le système judiciaire est dûment régi par les normes démocratiques, particulièrement les normes de représentation et de diversité. Les auteurs ajoutent, qu'à la lumière de ces normes démocratiques, les systèmes actuels de nomination des juges (et le système qui l'a mis en place) souffre de ce qu'ils appellent "un déficit démocratique ".

Après un examen détaillé d'essais de réforme du système, des arguments en faveur et contre une démarche de sélection plus démocratique et représentative et quelques modèles éventuels de sélection, les auteurs proposent leur propre réforme, soit l'établissement par la loi d'une commission de nomination judiciaire. Une telle démarche aiderait à pallier un déficit démocratique et produirait ce qu'ils appellent un système $\dot{a}$ trois $P$, c'est-à-dire politiquement responsable, professionnellement qualifié et proportionnellement représentatif.

\section{TABLE OF CONTENTS}

I. INTRODUCTION ......................736

II. LEGAL THEORY AND THE ROLE OF THE JUDGE:

FROM IDEALISM TO NEO-REALISM (OR FROM

HARNESSES TO BUNGEE CORDS) $\ldots \ldots \ldots \ldots \ldots \ldots \ldots \ldots 737$

\footnotetext{
- Professor, Dalhousie Law School.

- Professor, Dalhousie Law School, former Director Nova Scotia Human Rights Commission.

... Third year law student, Dalhousie Law School.

I We would like to thank Dr. Alexandra Dobrowolsky for suggesting this title to us.
} 


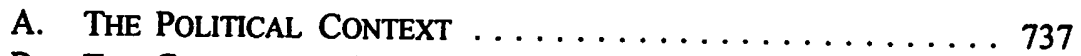

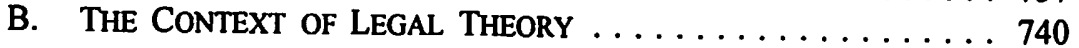

C. THe Political Dimensions of the Judicial

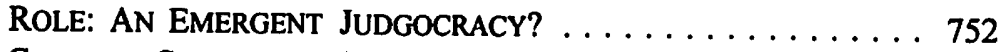

III. THE CURRENT Situation: A Democratic Deficit . . . . . . 758

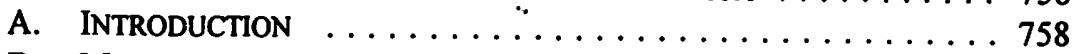

B. METHOdOLOGY $\ldots \ldots \ldots \ldots \ldots \ldots \ldots \ldots \ldots \ldots \ldots \ldots 759$

C. Results . . . . . . . . . . . . . . . . . . . . 759

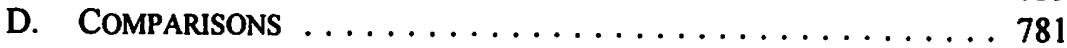

E. Summary $\ldots \ldots \ldots \ldots \ldots \ldots \ldots \ldots \ldots \ldots \ldots \ldots .788$

IV. BEING THERE AND SPEAKING UP: NORMATIVE

ARGUMENTS FOR AND AGAINST A PROPORTIONATELY

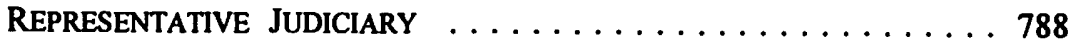

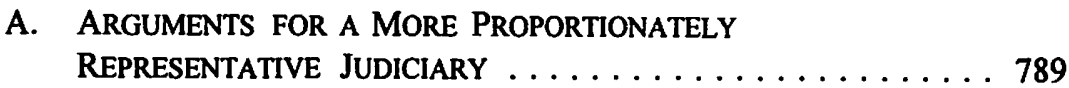

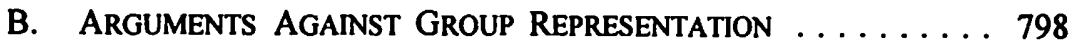

C. SUMMARY $\ldots \ldots \ldots \ldots \ldots \ldots \ldots \ldots \ldots \ldots \ldots \ldots$

V. FROM THEORY to INSTITUTIONAL DESIGN: OPTIONS FOR JUDICIAL APPOINTMENT PROCESSES $\ldots \ldots \ldots \ldots \ldots \ldots \ldots 812$

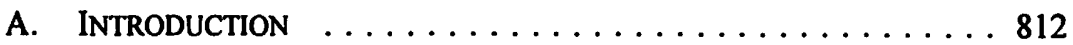

B. The Constitutional Framework $\ldots \ldots \ldots \ldots \ldots \ldots 814$

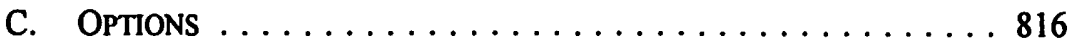

VI. TOWARDS A "TRIPLE P" JUDiCiary:

JUdicial APPOINTMENT COMMISSIONS $\ldots \ldots \ldots \ldots \ldots \ldots \ldots 827$

A. StATUTORY Status $\ldots \ldots \ldots \ldots \ldots \ldots \ldots \ldots \ldots$

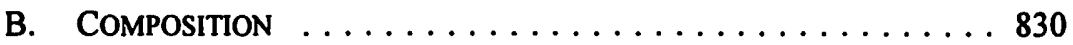

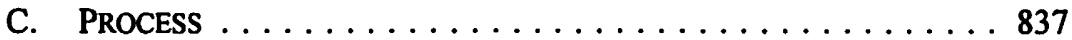

D. Criteria $\ldots \ldots \ldots \ldots \ldots \ldots \ldots \ldots \ldots \ldots \ldots \ldots \ldots \ldots$. 841

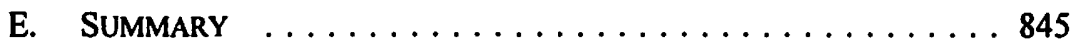

VII. CONCLUSION ..................... 845

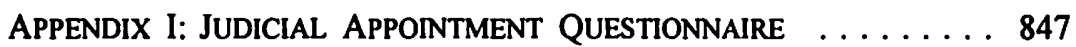

APPENDIX II: CRITERIA $\ldots \ldots \ldots \ldots \ldots \ldots \ldots \ldots \ldots \ldots .651$

APPENDIX III: CONTACTS $\ldots \ldots \ldots \ldots \ldots \ldots \ldots \ldots \ldots .862$

APPENDIX IV: BIBLIOGRAPHY OF JUDICIAL

APPOINTMENT REFORM PROPOSALS .............. 864

...there is no such thing as a 'neutral' system of representation. In practice all institutions of representation will have the effect of favoring some groups over others or of disadvantaging some groups more than others. ${ }^{2}$ 
Justice is a continual balancing of competing visions, plural viewpoints, shifting histories, interests, and allegiances. To acknowledge that level of complexity is to require, to seek, and to value a multiplicity of knowledge systems, in pursuit of a more complete sense of the world in which we all live. ${ }^{3}$

[F]or too many lawyers and judges, judging is still not regarded as the provision of a basic social service but the exercise of a private professional craft. ${ }^{4}$

\section{INTRODUCTION}

On January 11, 2000, Beverley McLachlin, on the day of her swearing in as the Chief Justice of Canada, "welcomed" a public debate on the way judges are appointed in Canada. ${ }^{5}$ This article is a response to that invitation. For more than three decades there have been many calls for reform of judicial appointment systems in Canada. In some cases, for example the Supreme Court of Canada, these calls have fallen on deaf ears. In other cases, in particular the appointment of provincial court judges, there has been quite significant reform. In our opinion, however, more needs to be done.

Canada is a heterogeneous democratic society characterized by widespread diversity and pluralism. However, one of the most powerful institutions in Canadian society, the judiciary, is relatively homogeneous. In this article, we submit that this apparent contradiction is indefensible. Building on John Stuart Mill's proposition that "the first principle of democracy is representation in proportion to numbers," that the judiciary needs to encompass a more proportional representation of the various communities that constitute Canadian society. In particular, we will argue that judging is an exercise of power, and that it is important in a democracy that the citizenry have a real opportunity to "be there" when power is exercised. Law is a terrain of social struggle in which contested social values representing diverse perspectives and communities are articulated and enforced. Our goal is to replace a relatively monopolized judiciary with a power-sharing judiciary, a judiciary that achieves a more equitable distribution of the scarce social good of judicial office. ${ }^{7}$

Our argument will proceed through five stages. Part II will argue that any discussion of judicial appointments is contingent upon an underlying conception of law and a theory of the judicial role. Part III is an empirical study which surveys the current appointment processes and the demographic profile of the Canadian judiciary: federally, provincially, and territorially. Part IV provides a theoretical consideration of the arguments for and against a proportionally representative judiciary. Part V maps out a series of institutional options, and Part VI makes some concrete suggestions for the

3 P.J. Williams, The Alchemy of Race and Rights (Cambridge, Mass.: Harvard University Press, 1991) at 121.

$4 \quad$ P. Russell, "Judicial Power in Canada's Political Culture" in M. Friedland, ed., Courts and Trials: A Multi-Disciplinary Approach (Toronto: University of Toronto Press, 1975) 75 at 88. Interview with $M$. Enright, CBC Radio (11 January 2000).

As quoted in $M$. Williams, supra note 2 at 46.

Our goal is a proportional sharing of power, not a veto power. As will become apparent later, when we discuss proportionality, we are not advocating absolute or direct proportionality, but rather approximate proportionality. 
creation of democratically constituted Judicial Appointment Commissions. Part VII, a brief conclusion, is followed by a series of appendices. The "golden thread" uniting the argument is that, while the recent emphasis on increased judicial professionalism is an improvement over the historical tradition of vulgar political partisanship, politics cannot (and should not) be eradicated from the appointments systems. Professionalism, therefore, needs to be supplemented by the democratic principle of proportionality. In short, we are calling for a "Triple P" judiciary: one that is politically responsible, professionally qualified, and proportionally representative.

\section{LEgAL THEORY AND THE ROLE OF THE JUdGe: FROM IdEALISM TO NeO-REALISM (OR From HARNESSES TO BUNGEe CORDS)}

The focus of this article is upon fairer and more democratic appointment processes that take account of the need for greater representation of non-traditional and marginalized groups within the ranks of Canadian judges. Judges operate within a larger and more complex web of political, social, and economic values that provide the context for defining the proper judicial role in Canada. In our opinion, one's views about judicial appointments are inevitably contingent upon one's views about the proper judicial role, which are, in turn, contingent upon one's understanding of the nature of law. More particularly, our views will be influenced by the theory of law we subscribe to, and by its implications for the nature and role of judging in society.

Before beginning our brief excursion into political and legal theory, it is important to sound a cautionary note about the dangers of labels and categories. Labels are, by definition, restricting and distorting. Nonetheless, a certain amount of categorizing is necessary to make sense of reality. So long as one remembers that categories are for convenience and not intended as a series of procrustean beds, they can serve a useful purpose. At a minimum, this Part should provide a glimpse of the diversity of perspectives that can be brought to disputes about the roles of judges and about who should serve as judges. It is also important that judges identify their own inclinations and perspectives because they will be influenced by these legal theories and larger political trends, whether consciously or not. ${ }^{8}$

\section{A. The Political Context}

As part of identifying our own perspective, we declare at the outset that we see judging as an inherently political process, and thus the role of the judge to be a political and law-making one. This does not mean that we see judges and legislators as one and the same; rather we think that both operate as a part of a continuum of institutions which exercise power. The difference between the courts and other institutions is one of degree, not of kind. This is an important distinction to which we will return later. Suffice it for present purposes to say that legal theory, like judging itself, must be seen

8 There are other pragmatic benefits to an awareness of judicial and political theory. As we shall argue in Part IV, a recognition of the diversity of views about law and judging could lead judges to be more open to a variety of voices in the courts and lead to greater representation within the judiciary. 
in the context of the larger political ideology of Canadian society. The "seamless web" of the law is one that is attached to the prevalent political structure of the day. Neither legal theory nor law is separated from the larger society that it is meant to serve. In these comments, we reveal what we will describe as our "neo-realist" inclinations in respect to the meaning of the nature of law.

Assuming that Canada has moved beyond the divine right of kings, a feudal structure of obligations and duties, and conservative theories of enlightened despotism, we label mainstream political thought as liberalism. ${ }^{9}$ Included in this term are both conservatism and liberalism in the more popular political sense. Liberalism, as an ideology, is based on the maximization of freedom of choice in all spheres of human endeavour. In political terms, this means an emphasis on the role of the individual in society and a championing of his or her free and democratic rights. In economic terms, liberalism translates into laissez-faire economics and into the glorification of free choice in the marketplace. There is also a legal component to liberalism, represented by the rule of law and by an emphasis on process values.

The role of the state as a liberal structure - whether in its political or judicial guises - is to provide an open process for the resolution of value disputes. Politically, this means an emphasis on democracy which, in theory, will produce representatives with a host of different perspectives and values. In the judicial arena, the emphasis is on value-neutral judges who will adjudicate the competing versions of reality presented by opposing counsel. Needless to say, this is the ideal and not the reality.

An essential ingredient of classic liberalism is the silence of the state on what constitutes the "good." The good, rather, is to be defined and pursued on an individual basis as much as possible, and the state should intervene only where one individual's pursuit of happiness harms that of another. This conception of liberalism predates the modern welfare state and the increasing acceptance of state interventions to maximize the "common good" and allocate resources. Such interference is a common occurrence, necessitating much more state intervention than would fit the ideal. The idealization of liberty and the pursuit of freedom are vital elements of liberal doctrine, but there is a growing awareness of the need to balance liberty against other rights, values, and interests.

What is described above is, of course, a caricature of the essential features of the liberal state and may not adequately reflect changes in the nature of the liberal state. For example, many critics would question whether the liberal state was ever really silent about what constitutes "the good" in society. ${ }^{10}$ There is also a growing acceptance of the need to balance classic values of liberty against individual and collective claims to equality and fairness in a democratic society. Indeed, the values

9 We recognize that elements of all of these older political theories are present in liberalism, but they have been subsumed by the latter. Nor do we claim that this brief summary of liberalism properly captures this political theory. Our goal is merely to set the general political context.

10 M.J. Sandel, Liberalism and the Limits of Justice, 2d ed. (New York: Cambridge University Press, 1998). 
implicit in the Charter of Rights and Freedoms " reflect both elements of the more classic definitions, and the more contexualized and pluralist versions of, the liberal state. The "free and democratic society" that is envisioned by s. 1 of the Charter is undoubtedly a liberal one, but it is also an open-textured society that leaves scope for both of the major legal theories that we will discuss below.

It is also the Charter that has sparked the increasingly public debate about the proper role of judges in making policy decisions about important social issues such as abortion, pay equity, human rights, sexual assault, and striking the proper balance between law and order in society. ${ }^{12}$. Many academics have commented upon how the Charter has changed the profile of the court as a significant policy-making institution, and extended the political role and nature of the judiciary itself. For example, Jamie Cameron argues:

The judiciary was less visible prior to the Charter, and few would have defined the courts as one of Canada's branches of government. Common law justice presented the judiciary as "neutral arbiters", whose task it was to find the facts and discover the truth quietly, objectively and impartially. Though a sniff of politics occasionally hung in the air, especially on decisions about the division of powers, a separation of law and politics was more compatible with cultural assumptions about parliamentary democracy. There can be little doubt that the Charter has transformed the courts and judiciary. No matter what interpretation it is given, the Charter affects public policy, and, willingly or not, the courts have entered the political thicket. As a result, the judiciary can no longer claim the mantel of neutral arbiters. Their increased power over the lives of Canadians has in turn sparked demands that the judges, their decisions and the system of justice be held accountable. ${ }^{13}$

It is not only academics and political commentators who have had to struggle with the role of the courts before and after the Charter, but also judges themselves. In RWDSU v. Dolphin Delivery Ltd., ${ }^{14}$ in describing judges as "neutral arbiters," Justice McIntyre refused to accept that the judiciary was a branch of government caught by the Charter. While it would be hard to deny that judges make policy, many (including judges) resisted the description of judges as political state actors. ${ }^{15}$ This resistance

Part I of the Constitution Act, 1982, being Schedule B to the Canada Act 1982 (U.K.), 1982, c. 11 [hereinafter Charter].

J.L. Hiebert, "Wrestling with Rights: Judges, Parliament and the Making of Social Policy" (1999)

5:2 Choices 3. "Judges and the Public Space" was a major session organized jointly by the Canadian Association of Law Teachers and the Canadian Law and Society Association, 6 June 1999, Sherbrooke, Quebec, to explore the proper role of judges in our society. The Charter has been a catalyst for pushing this traditional academic debate into the larger mainstream media and culture.

13 J. Cameron, "Toward a Theory of Responsible Justice" in Canadian Institute for the Administration of Justice, Open Justice ed. by M. Morrissette, W. MacLauchlan \& M. Oulette (Montreal: Éditions Themis, 1994) 135 at 149 [footnotes omitted].

$14 \quad$ [1986] 2 S.C.R. 573 at 600.

is Political scientists such as Peter Russell have been more open to a political analysis of judging for some time: P.H. Russell, The Judiciary in Canada: The Third Branch of Government (Toronto: McGraw-Hill Ryerson, 1987) [hereinafter Judiciary in Canada]. By contrast, lawyers like M.L. Friedland, A Place Apart: Judicial Independence and Accountability in Canada (Ottawa: Canadian Judicial Council, 1995) [hereinafter $A$ Place Apart] hold on to a more traditional view of judges 
may, in large measure, be explained by adherence to a more traditional legal theory and the more constrained role of the judge within that theory. ${ }^{16}$ We now turn to the context of legal theory within the larger political context in order to map out a more traditional conception of judging (idealism) which will be contrasted to a more contemporary understanding (neo-realism).

\section{B. The CONTEXT Of Legal Theory}

\section{IDEALISM: HARNESSED JUDGING}

Judges' conceptions of their role are vitally important. One such perspective can roughly be labelled idealism. This perspective assumes that law is a rational set of rules that can be discovered by judges and others by the use of logic. The idealist tradition conceives of law as a cognate of rationality; a set of ideas and ideals that can both inspire and channel human interactions within a society. Law and rights are individualistic in nature and part of the natural order of things. In this more traditional view, law is above politics and independent of it. Precedent and continuity are important values in a formalist process of interpretation.

Formalism is a term used to describe a particular form of judgment writing, but, more importantly, it is descriptive of a variant of judicial reasoning derived from idealism. A crucial tenet of idealism is that law is an autonomous entity with a coherence of its own. Logic and rationality are the watchwords of idealism, and law is seen as a set of rules and principles that make sense and therefore can be discovered by judges. The creation of categories and dichotomies is characteristic of this style of judicial reasoning. There is an almost scientific element to much of idealism. Judges who adopt the idealist approach to law are generally concerned about objectivity and a search for truth. Americans sometimes refer to idealism as "classical" legal thought, but no such classical legal period existed in Canada, not at least in the sense that it existed in the United States. ${ }^{17}$

Idealism has been an important influence on judges and how they approach the law. There is also a link between an idealist theory of law and a formalist style of judging. These connections are explored by Mark Gold:

A formalist style of judgment writing is not related logically to any one theory of law; one is just as apt to encounter formalism in a judgment ostensibly rooted in natural law as in one informed by a positivist theory of law. Nevertheless, there is a certain image of law that one tends to find implicit in a formalistically styled judgment, and that is the conception of law as originating outside the actual decision of the judge. That "outside" may be the will of the legislator, the perceived imperatives of

as autonomous and distinct in kind as well as in degree, from other political institutions in Canada. These differing visions about the role of law and judges in society also help explain the heated debates within judicial circles about a code of conduct for judges in Canada. Canadian Judicial Council, Ethical Principles for Judges (Ottawa: Canadian Judicial Council, 1998). Some judges argued that such rules unduly fettered the independence of judges.

17 D. Kennedy, "Towards an Historical Understanding of Legal Consciousness: The Case of Classical Legal Thought in America, 1850-1940" (1980) 3 Res. in L. \& Soc. 1. 
natural law, or that brooding omnipresence of the waiting to be discovered, but never created, common law. The common feature of all of these variations is the image of law and adjudication as somehow impersonal, objective and autonomous from the will of the judge. This view probably captures the public's general appreciation of courts and law, and remains an ideal around which much of the legal profession will rally. ${ }^{18}$

As Gold suggests, two major variants of idealism are natural law and positivism. Natural law, in its traditional form, insists upon a link between law and morality. Natural law accepts the existence of an external source for law beyond the everyday human experience. For some early theorists, such as Thomas Aquinas, this external source was divine. ${ }^{19}$

More recent proponents of natural law have down-played the external sources of law, but have not abandoned them. External sources of law can now be more secular and implicit in the conditions of group life. Lon Fuller suggests "there are external criteria, found in the conditions required for successful group living, that furnish some standard against which the rightness of [the judge's] decision should be measured." ${ }^{20}$ For Fuller, one of the common threads of natural law in all forms is the pursuit of the basic principles of the social order that would allow satisfactory community life. ${ }^{21}$ These principles represent a wedding of law and morality that is characteristic of natural law.22

Descriptions of natural law, as a discrete body of knowledge external to individual judges and morally based, are classic examples of idealism. It is the logic and rationality of the natural law that dictates certain legal results, not politics or the subjective views of a particular judge. Because of its appeal to morality or higher logic, it is an excellent rhetorical device for judges, whether or not they accept natural law theory. As we shall see, it is the potential use of natural law as a means of legitimating value choices that concerns the neo-realists and other critics of liberalism.

Positivism is another convenient legal theory for allowing judges to engage in value choices, while appearing to make a mechanical and logical application of the law. In Charter cases, it is difficult for judges to articulate a separation of legal and moral issues; but judges will continue to insist on a rule of law rather than surrender to

M.E. Gold, "The Mask of Objectivity: Politics and Rhetoric in the Supreme Court of Canada" (1985) 7 S. Ct. L. Rev. 455 at 461 [footnotes omitted].

19

The historical context of natural law is outlined in Q. Skinner, The Foundations of Modern Political Thought, vol. 1-2 (Cambridge: Cambridge University Press, 1978).

20

L. Fuller, "Reason and Fiat in Case Law" (1946) 59 Harv. L. Rev. 376 at 379.

L.L. Fuller, The Morality of Law, rev. ed. (New Haven: Yale University Press, 1969).
Not all modern writers accept this secularization of natural law. Canadian philosopher George P.

Grant articulates the following version of natural law:

There is an order in the universe which human reason can discover and according to which

the human will must act so that it can attune itself to the universal harmony. Human beings

in choosing their purposes must recognize that if these purposes are to be right, they must

be those which are proper to the place mankind holds within the framework of universal law.

We do not make this law, but are made to live within it.

Philosophy in the Mass Age (Vancouver: Copp Clark, 1966) at 29. 
admittedly subjective responses to complex political and moral choices. Positivism has also been redefined. The written law now includes the Charter in a pre-eminent constitutional form and thus expands the role of judges even within this theory. The "grundnorm"23 that must be accepted as part of the constitutional framework has been expanded to include the Charter. Nonetheless, positivists continue to insist on the limiting nature of the text and the continuing importance of drawing a clear line between law and politics. ${ }^{24}$

In our opinion, the conventional dichotomy between natural law and positivism has been overstated. They are both idealist theories and are only different points within a fairly narrow spectrum. There are, however, significant differences in emphasis. While natural law, in its idealized form, weds law and morals, positivism is dedicated to a separation of the two. Like natural lawyers, positivists see the law as a relatively coherent pattern of rules that is ascertainable. However, positivists emphasize the written law rather than some higher source, and are thus more secular in their approach. Further, they are also more relativist, because the written law can change over time. Thus, positivists are not as inclined to objective and immutable rules, although they do share with the natural lawyers the view that law is autonomous and rational.

The logical and rational aspects of positivism are emphasized in the writings of Hans Kelsen. ${ }^{25} \mathrm{He}$ appears to be concerned with empirical statements about the world that can be verified by observation and experiment. The critical issue for Kelsen is the manner in which statements about law can be verified in reality. Since only written laws are susceptible to such verification, they are the core of law. While moral judgments about the positivist law are relevant, they are distinct from law itself. Unlike the classical positivist lawyer, Kelsen separates the empirical question of what is from the moral question of what ought to be.

Another leading exponent of positivism is H.L.A. Hart. ${ }^{26}$ Consolidating the earlier works of Austin and Bentham, Hart identifies three major themes of positivism. First, there is a separation between law and morals. Second, the analytical and scientific study of legal concepts is important. Third, law is essentially a command. In Austinian terms, the command was that of the sovereign. ${ }^{27}$ Hart goes on to formulate positivism in a way that brings it closer to the natural law in its modern version.

H. Kelsen, Introduction to the Problems of Legal Theory, trans. B.L. Paulson \& S.L. Paulson (Oxford: Clarendon Press, 1992) at 56-60.

P.W. Hogg, "The Charter of Rights and American Theories of Interpretation" (1987) 25 Osgoode Hall L.J. 87.

H. Kelsen, What is Justice? (Berkeley: University of California Press, 1960); Pure Theory of Law, trans. M. Knight (Berkeley: University of California Press, 1967).

H.L.A. Hart, Essays in Jurisprudence and Philosophy (Oxford: Oxford University Press, 1983); Essays on Bentham (Oxford: Oxford University Press, 1982); "Positivism and the Separation of Law and Morals" (1958) 71 Harv. L. Rev. 593.

J. Austin, The Province of Jurisprudence Determined, ed. by I. Berlin, S. Hampshire \& R. Willheim (London: Weindenfeld \& Nicholson, 1954). 
Since positivists emphasize the written law, they have had to accept a hierarchy of authority with a special place for the rule-giver. The role of courts is fairly limited: except for the modest evolution of the common law, the primary source of the law is the legislature. Because positivism, like natural law, tends to be individualistic in focus, the surrender of authority to government has to be justified on the basis of a social contract. . $^{28}$

In this idealist view of the world, it is the role of the judge to translate these ideas (be they from natural law or positivism) into legal form and to enforce the legal commands in the individual cases which come before them. A central theme of idealism is that judicial choice is constrained and harnessed by the power of legal rationality. Since ideas are potentially accessible to everyone and transcend identity, ${ }^{29}$ and because the role of the judge is seen as the objective and structured application of the law, the questions of representation and the diversity of the judiciary are irrelevant, even "nonquestions. ${ }^{30}$

In political science as well as in legal theory, the judge is seen as harnessed in his or her choices and is expected to play a restrained role in respect to the articulation of public policy. The incremental development of the common law, and the application of law and policy as articulated by the elected legislators, are the hallmarks of the judicial role. The traditional perspectives on law send a clear message that a judge must be restrained in most matters, and, where possible, err on the side of caution. This has been the view of the judge as inherited from the United Kingdom, where the central constitutional premise is the supremacy of Parliament and where judges avoid the activist role of making public policy. Even as Canadian views about the proper role and function of judges have evolved with the advent of the Charter, there are still concerns about the appropriateness of judges entering the policy arena. Peter Russell puts the issue well:

Canada's judges are less well prepared for their new policy-making role under section 15 than they are for their additional responsibilities in relation to criminal justice policy. Most will lack familiarity with the social and economic programs that are likely to be challenged on section 15 grounds. The adjudicative process as it is now conducted in Canada is not well designed to enable judges to obtain a good understanding of the factual setting in which their decisions take place. But even if our judges produce policy results which coincide with our political preferences, I worry about what this judicialization of the resolution of equality issues will do to the quality of our political life. Deciding questions of distributive justice is an essential responsibility of political man [sic]. Political life, as Aristotle taught, rises above the organization of animal herds when it is characterized by man's distinctive capacity of expressing and exchanging ideas about right and wrong."

J. Locke, The Second Treatise of Government, ed. by T.P. Peardon (New York: The Bobbs-Merrill Co., 1952) and T. Hobbes, Leviathan (New York: The Bobbs-Merrill Co., 1958) are two examples. See also A. Phillips, The Politics of Presence (Oxford: Clarendon Press, 1995) at c. 1.

J.M. Vickers, "Memoirs of an Ontological Exile: The Methodological Rebellions of Feminist Research" in A. Miles \& G. Finn, eds., Feminism in Canada: From Pressure to Politics (Montreal: Black Rose Books, 1982) 37 at 38. 
The nature of the institution of judging puts limits on what individual judges can do. This is a fact of life recognized by many Canadian judges and most notably in written form by the late Chief Justices Laskin and Dickson. ${ }^{32}$ The constraints on judges are also a common topic for judicial speeches, whether in the form of comments on broad concepts, such as the rule of law and judicial independence ${ }^{33}$ or the limits implicit in the role of judging. ${ }^{34}$ Credibility and trust are the main sources of judicial power, and judges are concerned that if they step too far beyond traditional judicial bounds, their rulings will lose legitimacy.

Both the personal and institutional limits on the judicial role have been internalized by judges and manifest themselves in public statements about the judicial role, if not in their daily decision-making. In this articulation of the role, the individual identity of the judge is downplayed and the representative role of the judge rejected. In this regard, the words of the late Chief Justice Laskin responding to political criticism of the Supreme Court are instructive:

I do not represent the federal government, nor do I represent Ontario, which is my home province; I represent no one but myself; $I$ owe no allegiance, as a Judge to any person or to any interest; my duty, as I have already said, is only to the law. What is true of me is true of my colleagues; it is true of all appointed judges. ${ }^{35}$

In a more recent pronouncement by then Chief Justice Antonio Lamer, the continuing power of the idealist conception of the judge is again emphasized. Even while recognizing the increasingly public, and to some extent, political role of the judge, Lamer C.J. had this to say:

Judges are more than ever public figures. The decisions of judges are the subject of considerable public attention, sometimes well informed and sometimes not. From the public perspective, the courts do not just decide cases. The case itself often serves another public purpose. It provides a platform to draw attention to important questions of public policy....

While public interest in the courts' debate about what is just and how well courts do their job are all important in a democracy, we must also remember that the role of the judge is to decide, not to please, to give judgment not propaganda and to be faithful to the rule of law, not to the rule of external pressure, whatever the source.

In this respect, the role of the judge remains largely unchanged, although the context in which that role must be discharged has been transformed remarkably in this century. The challenge for the judiciary "The Judiciary - Law Interpreters or Law Makers" (1982) 12 Man. L.J. 1.

33 B.J. Dickson, "The Rule of Law: Judicial Independence and the Separation of Powers" (Canadian Bar Association, Halifax, Nova Scotia, 21 August 1985) [published by Canadian Bar Association], is one example. Toronto, 26 November 1985) (1986) 36 U.T.L.J. 227 [hereinafter "Decision Making"]. 
and for all who care about the rule of law is to preserve that role, while adapting it to the changing circumstances of the present and the future. ${ }^{36}$

Even more recently, Justice Binnie has suggested that judicial activism is only a danger when legislatures indulge in excessively broadly drafted legislation. ${ }^{37}$

In light of these sorts of claims (denials?), it would, therefore, be wrong to suggest that the conception of the judge as harnessed by the law, which emerges from the idealist view of the judge, is dead. It is still a powerful force which provides considerable resistance to calls for a more representative and diverse judiciary. However, there are also more modern legal theories that have increasing currency, and these theories allow for a more political judicial role in which representation and identity are relevant concepts. We shall now turn to these theories which we have labelled neo-realism.

\section{NEO-REALISM: BUNGEE CORD JUDGING}

The neo-realist approach conceives of law as a raw political fact: some members of society have the social power to dictate to others what is legally permissible and what is not. As Robert Cover reminds us,

Legal interpretation takes place in a field of pain and death. This is true in several senses. Legal interpretive acts signal and occasion the imposition of violence upon others. A judge articulates her understanding of a text, and as a result, somebody loses his freedom, his property, his children, even his life. ${ }^{38}$

Legislators are elected representatives who, as a result of the democratic principle, have legitimacy to determine the substance of law. By definition, legislators are meant to pursue their vision of the good. Interests, then, are just as important as ideals. Neorealism argues that the court system is an equally vital site for social struggle. Moreover, social struggle is understood to be much more complex than the conventional liberal/conservative continuum would lead us to believe. Just as important are identity-based conflicts founded on, for example, sexuality, race, gender, and disability.

Neo-realism proclaims that, inevitably, judges are political actors. Consequently, in a democracy, the judiciary should incorporate democratic norms. One such norm is

A. Lamer, "The Role of the Judges in the 20th Century" in Canadian Institute for the Administration of Justice, Open Justice (Montreal: Éditions Thémis, 1994) at 15, 19 and 22. The independence and impartiality of judges was a theme emphasized by Lamer throughout his tenure: judges were at all times to be above politics.

37 B. Laghi, "Top-Court Judge Denies Activism" The Globe and Mail (21 October 1999) A4; Editorial, "Judicial Activism is not a Figment of the Imagination" The Globe and Mail (26 October 1999) Al6.

38 R. Cover, "Violence and the Word" in M. Minow, M. Ryan \& A. Sarat, eds., Narrative, Violence, and the Law: The Essays of Robert Cover (Ann Arbour: University of Michigan Press, 1992) 203 at 203. See also "Decision Making," supra note 34 at 231. 
representation. Identity is an important dimension of representation. Therefore, it is not simply a question of what (ideas) the law is, but also a question of who (identity) gets to engage in the ongoing struggle that we call law, and for what purposes (interests). In other words, a neo-realist approach acknowledges the importance of ideas, but suggests that it is only one of several important influences on the judicial process; three others are identity, material circumstances, and ideology. It is this neo-realist version of the law that we embrace, and it forms the foundation for our call for a more representative and diverse judiciary.

We do not suggest that law is just a naked political struggle with power being the only variable, but rather that the law and the process of judging are far more political than the idealist theorists would suggest. It should also be emphasized that we do not use the term political in the narrow partisan or legislative sense, but rather as a description of the value choices and large discretionary component in judicial decisionmaking. Judges engage in politics of a somewhat different character than that pursued by the other branches of government, and the discretion exercised by judges is not completely unharnessed. However, it is not the restrictive rationality or harness relied upon by the idealist school of legal theory. Rather, it is more like the restraint of a bungee cord: it leaves a lot of room for creative movement and flexibility, but at the end of the day, provides some restraint.

What do we mean by the term neo-realism? It is an umbrella term in which we include a number of schools of legal thought that have arisen in reaction to the more traditional idealist views of law. There are many strands to the neo-realist version of law, but several are particularly relevant to this article. First, law is understood to be in a state of constant flux and to require a purposive and contextual interpretation. Law is not an end in itself, but a means to an end, and is, in that sense, instrumental. Second, contrary to the idealist dogma, real life experience, and not reason, is the backbone of the law; and consequently, there is often a gap between the letter of the law and the application of law on the front lines. Third, in order to assess the real world experience of law, neo-realists stress an inter-disciplinary and context-sensitive approach to legal problems. Fourth, there is also a general acceptance of the subjective role of the judge in making and applying law, and thus, an acknowledgement of the political dimensions of judging.

Historically, neo-realism has its origins in the sociological school of legal thinkers and so-called realists, which emerged in the 1920's and 1930's in the United States. Members of the sociological school were the first clearly to reject idealism as an explanatorily adequate legal theory. Oliver Wendell Holmes predates the sociological school, but he expressed its essence when he proclaimed, "[t]he life of the law has not been logic: it has been experience." 39 It was Roscoe Pound, as Dean of Harvard Law School, who developed the theory of sociological jurisprudence and coined the phrase 
"mechanical jurisprudence" to describe the idealism that he rejected. ${ }^{40}$ Justice Benjamin Cardozo applied Pound's theory to the task of judging and expounded his insights in a series of famous lectures. ${ }^{41}$

The sociological school represents more than a rejection of idealism; it also advances a clear statement of an instrumental approach to law. If legal conclusions are not logically dictated, then something else must explain them. According to the sociological school, the explanation is to be found in understanding law as an instrument for the promotion of shared social goals within a society. The important thing was the goal being pursued and not the logic and/or the methodology. Cardozo clearly articulated this aspect of the theory:

Not the origin, but the goal, is the main thing. There can be no wisdom in the choice of a path unless we know where it will lead. The teleological conception of his function must be ever in the judge's mind. $^{42}$

Because of the shift of emphasis from the internal logic of the law to the social goals it was designed to achieve, there was a need for extra-legal sources to resolve legal disputes. Social facts, rather than arid law, became the order of the day. Jerome Frank referred to himself as a fact skeptic and insisted that, even if a rule were relatively clear, the lower courts and juries decided cases on the basis of their interpretation of the facts. ${ }^{43}$

As Denise Réaume indicates, there are clear links between the American school of sociological jurisprudence and jurisprudential thinking in Canada. ${ }^{44}$ This is most notable with respect to Bora Laskin, who studied under Felix Frankfurter in the United States, and under and with Caesar Wright in Canada. The influence of the sociological school on Laskin is reflected both in his speeches and his academic writings. ${ }^{45}$ Like many judges, Laskin's views reflected a mix of the idealist and realist schools, but, in the following passage, he reveals an acceptance of the subjective and human element of judging:

It is no longer sensible, if it ever was, to seek to depersonalize the judicial role by saying that the Judge owes fidelity only to the LAW, that the judge is merely the instrument that brings forth the law, as if the judicial function consists in pulling the right levers or pushing the relevant buttons. ${ }^{16}$

R. Pound, "Mechanical Jurisprudence" (1908) 8 Col. L.R. 605. Pound's views are more fully developed in An Introduction to the Philosophy of Law (New Haven: Yale University Press, 1954). B. Cardozo, The Nature of the Judicial Process (New Haven: Yale University Press, 1921). lbid. at 102.

J. Frank, Law and the Modern Mind (New York: Brentono's, 1930). apparent at the academic as well as judicial levels.

Ibid. at 442-47.

46 B. Laskin, "A Judge and His Constituencies" (1976) 7 Man. L.J. 1 at 2-3. It is interesting to note that this view is in rather sharp contrast to the more idealist view of judging that Laskin expresses, supra note 32. 
A judge's social background influences on her or his choices, and views of the role of the judge must account for that influence. The particular experiences of a judge can even affect her or his view about the appropriate forum for raising a legal issue. Laskin's experiences as a labour arbitrator and student of the sociological school of jurisprudence may explain his preference for resolving issues of social and economic equality outside the court. ${ }^{47}$ Cardozo recognized these background influences, but did not decry them:

All their lives, forces which [judges] do not recognize and cannot name, have been tugging at them - inherited instincts, traditional beliefs, acquired convictions; and the result is an outlook on life, a conception of social needs, a sense in James' phrase of "the total push and pressure of the cosmos," which when reasons are nicely balanced, must determine where choice shall fall."

This realist theory of the law emphasizes that judges make choices, and that they must look to broader social facts to make good choices. Law is not autonomous, but part and product of the larger society. These insights have obvious implications for judging. Judges cannot simply rely on mechanical rules; they must be prepared to make value choices after being informed by a wide range of sources.

Another strand in the web of legal theories that make up the neo-realist school is interpretivism. Drawing upon the realist's interdisciplinary approach to the law, these theorists borrow from interpretive principles in literary criticism to stress that it is the reader of the text, rather than the words of the text itself, which determines meaning. Thus, the text and the ideas that underlie it are not the restraint on judicial interpretation that idealist legal theory would suggest. That is not to say that the text imposes no limits on judges, but that these limits are flexible and elastic. One of the restrictions on judicial interpretation is the existence of a legal interpretive community, which would regard an interpretation that was not in accordance with the shared values of society (presumably including a constitutional commitment to a free and democratic society) as an "off the wall" or unacceptable interpretation. As we shall argue later, the importance of having a diversity of judicial backgrounds in determining the shared values of society supports the need for a more representative judiciary.

The foregoing discussion makes it clear that the interpreter of the legal text and her or his subjective views are important. The crucial locus of interpretive power is the interpreter and not the text per se or the intentions of its legislative author. This is no longer controversial. The real debate is about how subjective or objective the interpretation of the relevant text can be. Fish makes the following comment about the text and the reader:

[T] he objectivity of the text is an illusion and, moreover, a dangerous illusion, because it is physically convincing. The illusion is one of self-sufficiency and completeness. A line of print on a page is so and Administrative Law: An Unfinished Journey" (1985) 35 U.T.L.J. 557. 
obviously there ... that it seems to be the sole repository of whatever value and meaning we associate with it. ${ }^{49}$

On one side of the subjective-objective debate is Ronald Dworkin, who supports an objective approach to interpretation in Law's Empire. ${ }^{50} \mathrm{He}$ describes interpretation as the search by the Herculean judge for the "right answers" within the general context of legal rules or principles. Dworkin represents a view of legal interpretation that stresses continuity with the past and the evolution of law as a collective and objective enterprise. He compares judges to writers of a chain novel, with the greatest discretion resting with those who wrote the early volumes:

Each judge must regard himself [sic], in deciding the new case before him, as a partner in a complex chain enterprise of which these innumerable decisions, structures, conventions, and practices are the history; it is his job to continue that history into the future through what he does on the day. He must interpret what has gone before because he has a responsibility to advance the enterprise in hand rather than strike out in some new direction of his own. ${ }^{31}$

Within the Charter context, the rules of the game are a "free and democratic society" and within that framework, the interpreters of the text must search for the best answers.

For some members of the neo-realist school of legal theory, the insights of the realists and Dworkinian interpretivists are a helpful starting point, but do not go far enough. Joseph Singer, an adherent of critical legal studies, views the role of the interpreter as much more subjective, and he makes no apology for this. In a review of an American judge's decision, he points out:

\begin{abstract}
According to Justice Pashman, the question is not whether judges should make law, but whose interests they should protect. He sought to increase the number and variety of situations in which the legal system would require the community to come to the aid of the weak and disadvantaged in times of crisis. He also believed that the good society would be more egalitarian than the one in which we live. He therefore used his power to redistribute certain social and economic advantages from the privileged to the powerless. Was this an abuse of his judicial power? The answer depends not on abstract homilies about the judicial role, but with whom we place our sympathies. ${ }^{52}$
\end{abstract}

One of the major problems with the theories of the early sociological school and with intrepretivism in its objective guise is that each assumes a relatively homogenous society in which there are shared views about what is good. The realists who emerged from the sociological school recognized that there are conflicting groups in society who pursue different sets of goals. When the state steps in to make value choices, it must

S. Fish, Is There a Text in This Class: The Authority of Interpretive Communities (Cambridge, Mass.: Harvard University Press, 1980) at 43.

so $\quad$ R. Dworkin, Law's Empire (Cambridge, Mass.: Belknap Press, 1986). 
favour one group over another. Dissension and fragmentation, rather than consensus and cohesion, characterize modern society and law.

For example, a Marxist or leftist critique identifies social class as a critical aspect of judging, as it is in other political processes. Feminists emphasize the importance of gender and other aspects of identity politics. ${ }^{53}$ The relatively new field of Critical Race Theory ${ }^{54}$ identifies race as a key variable in society and, therefore, judicial decisionmaking. Finally, the Critical Legal Studies movement, which began in the United States and draws upon European theorists, applies a leftist critique to law, but in its more modern variants tries to include other perspectives based on gender and race, as well as social class. Together, these various approaches can be said to coalesce into neorealism, and it is these perspectives which are at the heart of many arguments for a more diverse judiciary. ${ }^{55}$

Neo-realism proposes a direct challenge to liberal legalism. Neo-realists do not wish merely to tinker with the existing legal structure, but to reconstruct it to be more inclusive. Unlike many of their predecessors, adherents of neo-realism consider themselves part of a broader political movement in pursuit of equality. By denying the autonomous existence of law and revealing the inherent tensions of the liberal state, neo-realism is built upon the primary insights of the realists. ${ }^{56}$ There is no agreed set of political principles for neo-realism, nor is there a single methodology, but there is a concern with the link between scholarship and practice on one hand, and the struggle for a more humane, egalitarian and democratic society on the other. ${ }^{57}$ Neo-realists seek to explore the deep structures of law that underlie the surface of legal reasoning. And they challenge not only the rationality and coherence of traditional legal theories, but also the claimed objectivity and neutrality of the judge.

The attack on objectivism is complex. In terms of adjudication, the objectivism of the liberal state emerges in the form of neutral principles, i.e. the ideal that judges do not impose values but decide cases on the basis of neutral principles. Paul Brest refutes such a claim:

The fact is that all adjudication requires making choices among the levels of generality on which to articulate principles, and all such choices are inherently non-neutral. No form of constitutional

See, e.g., C.A. MacKinnon, Toward a Feminist Theory of the State (Cambridge, Mass.: Harvard University Press, 1989).

See, e.g., K. Crenshaw, Critical Race Theory: The Key Writings that Formed the Movement (New York: New Press, 1995).

I. Grant \& L. Smith, "Gender Representation in the Canadian Judiciary" and E.P. Mendes, "Promoting Heterogeneity of the Judicial Mind: Minority and Gender Representation in the Canadian Judiciary," in Ontario Law Reform Commission, Appointing Judges: Philosophy, Politics and Practices (Toronto: Ontario Law Reform Commission, 1991) at 57 and 91.

57 D. Kennedy \& K.E Klare, "A Bibliography of Critical Legal Studies" (1984) 94 Yale L.J. 461 at 461. 
decisionmaking can be salvaged if its legitimacy depends on satisfying Bork's requirement that principles be "neutrally derived, defined and applied."ss

As a result of neo-realism, there is emerging a more modern conception of the role of the judge which is more tolerant of elements of subjectivity and discretion. To completely factor out the subjective element in judging would render the process mechanical and inhuman. It would also be impossible to do so. Rather, it is argued that recognizing one's biases may be the best route to impartial judging. ${ }^{59} \mathrm{~A}$ healthy skepticism about achieving the ideal of objective judging sets the stage for arguments in favour of a more representative and diverse judiciary as well. As we shall discuss in Part IV, it is proper to argue that the inclusion of a variety of perspectives will lead to greater open-mindedness and more ways of seeing the world. Exposure to this diversity of perspectives would allow judges to more directly confront stereotypes and assumptions which may underlie the judging process.

Another important aspect of the modern variants of neo-realist theory is the importance of putting both law and judging in their proper context. This is true of feminism and Critical Race Theory, as well as of Critical Legal Studies. Theorists from all of these schools agree on the importance of context, but may differ on which context should prevail in a particular situation. It has even been suggested that contextualism has been recognized by the Supreme Court of Canada as the new standard for judicial reasoning. ${ }^{60}$ Like the demise of objectivity, the rise of contextualism is a further argument for a more diverse judiciary, as judges with different backgrounds can best appreciate the variety of contexts in which the law applies. Among those contexts are experiences of disadvantage and marginalization, which Professor Mendes argues should be represented at the judicial conference table. ${ }^{61}$

The neo-realist theory of law also recognizes the importance of differences in society and acknowledges that identity based upon social class, disability, gender, race, and other characteristics is important. Society is not a homogenous unit, as some liberal thinkers would assume, but a mixture of many different groups and communities. Indeed, politics in all its forms (including the judicial form) is about engaging conflicting interests in society and making value choices about which interests should prevail in a particular situation.

Thus, to summarize our position metaphorically, we might characterize our position as a "bungee cord theory of judgment": judges are not untethered, but their discretion is very elastic and extremely flexible. Numerous variables inform the length of the cord and the extent of its flexibility, and when it does spring back into shape, it will often

P. Brest, "The Fundamental Rights Controversy: The Essential Contradictions of Normative Constitutional Scholarship" (1981) 90 Yale L.J. 1063 at $1091-92$ [footnotes omitted].

s9 $\quad$ B. Wilson, "Will Women Judges Really Make a Difference?" (1990) 28 Osgoode Hall L.J. 507 [hereinafter "Women Judges"].

w S.M. Sugunasiri, "Contextualism: The Supreme Court's New Standard of Judicial Analysis and Accountability" (1999) 22 Dal. L.J. 126.

61

Mendes, supra note 55. 
span farther than it did before. Ideology, experience, position, and identity are but a few influential variables that inform judging and the value choices of judicial decision makers. The next section discusses how this breadth of judicial discretion impacts on the political and social climate in Canada.

\section{The Political Dimensions of the Judicial Role: AN EMERGENT JUDGOCRACY?}

One of the most important consequences of accepting the neo-realist theory of law over the idealist one, is the recognition that the role of the judge is a political one which involves making choices between competing ideas, interests, and ideologies in society. We also conclude that this political process is one in which identity and representation are not only relevant, but vital factors. At the risk of understatement, a Canadian judiciary which is largely drawn from a homogenous elite is a problem. Representation from those who have been traditionally marginalized in our society is vital, not only to traditional political institutions, but also to the courts. It is not only a question of faimess and equality, but also one of legitimacy.

The significance of the experiences and backgrounds that individual judges bring to the task of judging has been increasingly recognized within both judicial and academic circles. While the Charter has brought this issue to the foreground, it is relevant to all aspects of judging and, as Andrew Heard suggests, has important implications for the judicial appointment process:

The actual manner in which the judiciary interpret the practical substance of the Charter is of crucial importance. Canadians have tended to ignore the significance of individual judges in favour of a mythology about the collective decisions of "the court". If the underlying predispositions of judges play a pivotal role in judicial interpretations of our fundamental rights, we must recognize this and account for it in both our general theories of civil rights and in particular suggestions for improvements to the judicial decision-making process. We may also wish to consider changes to the judicial appointment process that will fully account for the importance of candidates' views on Charter issues. $^{62}$

Not only are judges as individuals important political actors, but the process by which judges reach decisions and form majorities and minorities is also a profoundly political one. This dimension of the judicial role has also become the subject of both judicial and academic study. ${ }^{63}$ While the focus of much of this previous study is the Supreme Court of Canada and, in particular, the Charter decisions, the conclusions reached are also applicable to different courts and different legal issues. 
It has been recognized for some time that the Supreme Court of Canada is an important national institution with political dimensions. ${ }^{64}$ As this article is being written, a major political topic on the Canadian agenda is the conflict and controversy surrounding the rights of the Mi'kmaq to fish in the Atlantic pursuant to their constitutional treaty rights under a 1760 treaty. This highly political controversy was triggered by the decision of the Supreme Court of Canada in the Marshall case ${ }^{65}$ in which the Justices of the Supreme Court of Canada concluded that the 1760 treaty does provide the legal basis for a native fishery, and that this ancient treaty right has also acquired constitutional status as a result of s. 35 of the Constitution Act, $1982 .^{66}$ The fact that the Supreme Court of Canada was divided 5-2 in the case emphasizes that this was not just an application of pre-ordained legal principles, but a complex interpretation process involving both the balancing of conflicting interests and the making of important value choices. Not only has the Marshall case sparked political controversy, but the decision itself was a politicized process in the broad sense. But we want to emphasize that it is not just the Supreme Court of Canada that is political, but that the entire process of judging has an irrepressible political dimension.

The role of the Supreme Court of Canada and the lower courts in giving content to the broad language of the Charter is the highest profile example of the policy-making role of the courts. ${ }^{67}$ Balancing individual rights against the reasonable limits of a free and democratic society is a value laden process that involves the courts in making public policy and choosing between conflicting interests in society. Abortion, ${ }^{68}$ pornography, ${ }^{69}$ hate speech, $^{70}$ assisted suicide, ${ }^{71}$ mandatory retirement, ${ }^{72}$ gay rights, ${ }^{73}$ and the definition of the family for legal purposes ${ }^{74}$ are but a few examples of the important value choices that courts have made under the Charter and the high profile policy-making role that the judges exercise. ${ }^{75}$

While the Charter is the most high-profile manifestation of the political role of courts, it is not a new role. In matters of federalism and Aboriginal rights, judges have always been policy-makers, as the rules of division of powers contained in the

A.W. MacKay \& R. Bauman, "The Supreme Court of Canada: Reform Implications for an Emerging National Institution" in C. Beckton \& A.W. MacKay, eds., The Courts and the Charter (Toronto: University of Toronto Press, 1985) [hereinafter "Reform Implications"]; "Effect of a Charter," supra note 31, and other political scientists have also recognized this for sometime.

R. v. Marshall (1999), 177 D.L.R. (4th) 513.

Being Schedule B to Canada Act, 1982 (U.K.), 1982, c. 11.

A.W. MacKay, "Judging and Equality: For Whom Does the Charter Toll?" in C. Boyle et al., eds., Charterwatch: Reflections on Equality (Toronto: Carswell, 1986) 35; Heard supra note 62; I. Greene et al., Final Appeal: Decision-making in Canadian Courts of Appeal (Toronto: James Lorimer, 1998) [hereinafter Final Appeal] are just a few examples which support this view.

$R$ v. Morgentaler, [1988] I S.C.R. 30.

R. v. Butler, [1992] 1 S.C.R. 452.

R. v. Keegstra, [1990] 3 S.C.R. 697.

Rodriguez v. British Columbia (A.G.), [1993] 3 S.C.R. 519.

McKinney v. University of Guelph, [1990] 3 S.C.R. 229.

Egan v. Canada, [1995] 2 S.C.R. 513; Vriend v. Alberta, [1998] I S.C.R. 493 [hereinafter Vriend]. Canada (A.G.) v. Mossop, [1993] I S.C.R. 554; M. v. H., [1992] 2 S.C.R. 3.

This increasingly political role for courts under the Charter has sparked a cottage industry of academic writing on the topic. 
Constitution Act, 1867 are neither clear nor self-evident. Even fairly conservative legal scholars, such as the late William Lederman, have acknowledged that there is a significant component of policy and value choice in deciding whether a matter falls with federal or provincial jurisdiction. ${ }^{76}$ Deciding who has jurisdiction over natural resources is clearly an exercise in balancing competing interests and claims. It was also judicial policy-making when the courts historically were ruling against Aboriginal rights, just as much as it is now, when they often appear to be deciding in favour of Aboriginal rights. The courts, in short, played an important political role even before the advent of the Charter. ${ }^{77}$

Even at the structural level, Canadian courts have been given a political role in our constitutional architecture. Canada does not have a clear separation of powers (a separation of legislative, executive and judicial roles) as exists under the American Constitution. The reference mechanism - by which the federal Cabinet may refer any matter it deems important to the Supreme Court of Canada, ${ }^{78}$ and the provincial Cabinets may refer any such matter to provincial appeal courts $^{79}$ - is but one acknowledgement of the role of the courts in advising government on constitutional issues. ${ }^{80}$ Challenges to this exercise of judicial power, as being too political in nature and blurring the lines between the various branches of government, have been consistently rejected. The most recent context in which the role of the courts in advising government through the reference mechanism was upheld is the Quebec Secession Reference. ${ }^{81}$ There is no Canadian equivalent to the "political questions" doctrine as it has developed in the United States. ${ }^{82}$ This reference power has plunged the Supreme Court of Canada and provincial appeal courts into some of the major political disputes of the day. ${ }^{83}$

While the constitutional role of the courts is a good example of their policy-making role, it is by no means the only example. Throughout Canadian history courts have been involved in judicial review of the executive branch of government. Indeed, the power of judicial review in respect to all levels of the executive branch of government has been implied by the courts even when the statute itself is silent. ${ }^{84}$ The broad powers of judicial review for legal and jurisdictional error, as well as procedure and abuse of

W.R. Lederman, "The Concurrent Operation of Federal and Provincial Laws in Canada" (1963) 9 McGill L.J. 185.

P. Weiler, In the Last Resort: A Critical Study of the Supreme Court of Canada (Toronto: Carswell, 1974) provides one of many examples of this point.

Supreme Court Act, R.S.C. 1985, c. S-26, s. 53.

See e.g. Constitutional Questions Act, R.S.N.S. 1989, c. 89.

F. Vaughan, "Judicial Politics in Canada: Patterns and Trends" (1999) 5:1 Choices 4.

The argument that the secession of Quebec from the rest of Canada was a political and not a legal question was soundly rejected by the Supreme Court in Reference re Secession of Quebec, [1998] 2 S.C.R. 217 [hereinafter Quebec Secession Reference].

Operation Dismantle v. $R$, [1985] I S.C.R. 441 at 443, per Wilson J.

Quebec Secession Reference, supra note 81; Reference re Resolution to Amend the Constitution, [1981] 1 S.C.R. 753; Re Manitoba Language Rights, [1985] I S.C.R. 721 [hereinafter Manitoba Language Reference] to name but a few.

J. Evans et al., Administrative Law: Cases, Text, and Materials, 4th ed. (Toronto: Emond Montgomery, 1995). 
discretion, give judges significant leeway to control and limit executive power. While judges are notionally leaving the merits and policy of the decision to the bureaucrats, the line between policy and process is a thin one. One example of the political role of the courts in this area is the decision to limit the role of administrative agencies in dealing with the Charter. The decision as to whether Charter rights should be adjudicated in courts only, or also in administrative tribunals, is an important policy choice, as well as a legal one. ${ }^{85}$

Another illustration of the political role of the courts is the fashioning of remedies. Although recognizing the primary legislative role in providing a remedy for social problems, judges have increasingly asserted a role as the upholder of the Constitution. ${ }^{86}$ In the Schacter ${ }^{87}$ case, the Supreme Court validates its right not only to strike and read down legislation, but also to read in statutory language to make a statute conform with the Constitution. The most controversial example of this occurred when the Supreme Court of Canada read the term "sexual orientation" into Alberta's Individual Rights Protection Act, in direct conflict with the Alberta legislature's clear intention to exclude gays and lesbians from the protection of the statutory human rights scheme. $^{88}$

As a final example of the political dimensions of the judicial role, consider the large element of discretion in judging. Of course judges, like other institutional players, must operate within the law - constitutional, statutory, and common law - but through the flexible powers of application and interpretation, discussed earlier, they have the luxury of defining their own limits. Judges do not choose the cases that they must adjudicate (except to the extent that leave of the court must be sought in certain cases), but they do have considerable discretion as to how the case is to be resolved. There are also choices about what evidence to admit and what weight to assign to the evidence. The judge can decide whether to resolve the case on broad or narrow terms or, in some cases, whether to resolve the dispute at all - depending upon whether she or he sees the judge's role as one of restraint or activism. ${ }^{89}$ Which parties appear before the judge is even partly a matter of discretion. ${ }^{90}$

The political dimensions of judging are not unique to the appeal courts, but are equally present at the trial level. Consider the two areas of law that occupy the majority of judges' time: criminal and family law. These areas involve profoundly political

8s Cooper v. Canada (Human Rights Commission), [1996] 3 S.C.R. 854.

86 Manitoba Language Reference, supra note 83.

$87 \quad$ Schachter v. R., [1992] 2 S.C.R. 679.

88 Vriend, supra note 73.

89 Mootness is largely a matter of judicial discretion (Borowski v. Canada (A.G.), [1989] 1 S.C.R. 342).

so Standing and intervention are largely matters of judicial discretion. See Thorson v. Canada (A.G.), [1975] 1 S.C.R. 138; Nova Scotia Board of Censors v. McNeil, [1976] 2 S.C.R. 265; Canada (Minister of Justice) v. Borowski, [1981] 2 S.C.R. 575. The pervasive role of discretion in judging at the appeal level is thoroughly documented in the recent book by Greene et al., Final Appeal, supra note 67. 
matters. In criminal law, class is often a major variable; so too is race. ${ }^{91}$ Sentencing at the trial level is a classic example of the difficult social balancing that judges must do. Striking the proper balance between the individual rights of the accused and the collective interest in law and order in society is a delicate and value-laden task. Family law is another area where judges make significant social policy choices in matters such as the custody of children, the definition of the family, and the fair distribution of assets upon the dissolution of marriage. ${ }^{92}$ Gender conflict is pervasive. Even contract and tort law incorporate important political choices. ${ }^{93}$ Consider again the law of evidence; one of the inescapable tasks of most trial judges is to make determinations of credibility, but such determinations will be influenced ("contaminated") by at least two variables: the context of the witness and the perspective of the judge. ${ }^{94}$ Both of these variables are dependent upon larger social and political forces.

Social science evidence provides further support for our claim as to the inherently political nature of courts, ${ }^{95}$ both institutionally and individually. Greene et al. identify "[t]hree common definitions of "politics" [as] the process of making decisions about who gets what, when and how; private demands, displaced into the public arena, and rationalized in terms of the public good; and the authoritative allocation of values for a society." The authors continue: "[c]ourts, as well as legislatures and executives, can be said to fit into all three of these viewpoints." ${ }^{96}$ Moreover, on the basis of recent interviews, they point out that most Supreme Court and appellate court justices acknowledge that they have significant law-making powers ${ }^{97}$ and that about half are not too worried by it. ${ }^{98}$ Furthermore, a series of quantitative studies of judicial voting patterns have indicated that the personal characteristics of judges (e.g. region of origin, religious affiliation, social class, political background, and length of judicial experience) have had significant impact on judicial decision-making. ${ }^{99}$ Similarly, a recent study

R. v. Williams, [1998] 1 S.C.R. 1128.

It is hard to imagine a more flexible standard than the "best interests of the child" rule. In contracts, courts are imposing standards of good faith, fiduciary relations, and community morality; in torts, they are, among other things, dictating professional norms.

J. Frank, Courts on Trial: Myth and Reality in American Justice (Princeton: Princeton University Press, 1949) at 14-36.

See e.g. "A Symposium: Social Science Approaches to the Judicial Process" (1966) 79 Harv. L. Rev. 1551; "Symposium on Judicial Behaviour" (1983) 5 Political Behaviour at 3.

Green et al., supra note 67 at $\mathrm{x}$-xi [footnotes omitted].

Ibid. at $95-97,125-128,186-188$. The number of judges who acknowledge that they do have a law-making role has greatly increased.

lbid. at $188,193$.

See e.g. C.N. Tate \& P. Sittiwong, "Decision Making in the Canadian Supreme Court: Extending the Personal Attributes Model Across Nations" (1989) 51 Journal of Politics 900 . For a discussion and elaboration, see Heard, supra note 62 . One possible objection to these studies is that, while they may be accurate as analyses of the patterns of the Supreme Court justices, they are irrelevant for lower level judges because institutionally the latter have significantly less discretion. While there may be some truth to this, Justice Gerald Seniuk reflects that "legal proof and the process of legal reasoning in the determination of guilt or innocence can depend on a subjective belief that is almost impervious to rational analysis," and that chance, not reason, may be determinative in difficult cases: "Judicial Fact-Finding and a Theory of Credit" (1992) 56 Sask. L. Rev. 79 at 79, 85. See also P. McCormick \& 1. Greene, Judges and Judging: Inside the Canadian Judicial System (Toronto: Lorimer, 1990) at 242. 
of Canada's appellate court judges conclusively concludes that judging is a "human process" that "...likely ... bear[s] close relation to the backgrounds and family contexts of the judges...."100

To be clear, when the claim is made that judges are political actors and that the judiciary is a political institution, we are not claiming that they are the same as politicians and legislators. Rather, the distinction is one of degree, not of kind. It is the form, forum, and processes that are different, not the ultimate function. It is the exercise of state power. Thus, in the same way that society acknowledges that bureaucrats and the bureaucracy wield political power in a particular form and forum, ${ }^{101}$ so too do judges and the judiciary. We do not assert that judges are political actors like the rest but rather that they are political actors of a certain character, who operate in their own particular form and forum. Courts, nonetheless, engage in the kind of interest and value choices that characterize a political process. They are part of the contested terrain within which value disputes are resolved.

So, while there are clearly important distinctions between judges and politicians, the primary point is that judges fulfil a highly political role in society. Indeed, the evidence suggests that we might be witnessing the emergence of a judgocracy, an elite that determines many of Canada's fundamental issues of social policy, but absent effective mechanisms of democratic accountability. ${ }^{102}$

Mechanisms of accountability can be either ex ante or ex post. In the conventional political arena, elections are the obvious example of an ex post system: if the politicians fail to respond to the demands of the electoral majority, they can be removed from office. On the contrary, because of our commitment to judicial independence, removal from judicial office is almost impossible. ${ }^{103}$ As a result, for judges the only other potential mechanisms for ensuring accountability and responsibility must be ex ante, that is, by means of the appointments process. Thus, the focus of Part III of this article is an assessment of the current appointments procedures to consider the extent to which they are capable of responding to the demands of democratic accountability so as to guard against the danger of an unaccountable judgocracy. This will then set the scene for further discussions in Part IV of whether the judiciary should be subject to democratic fundamentals such as representation, proportionality, transparency, and openness.

Finally, given that we have located ourselves jurisprudentially as neo-realists, and in light of the fact that we have argued that the judicial function is inherently and inescapably political, it is also incumbent on us to locate ourselves politically: we are pluralist constitutional democrats. As democrats, we are committed to participatory,

100 Green et al., supra note 67 at xi.

101 D. Beethan, Bureaucracy (Minneapolis: University of Minnesota Press, 1987).

102 Democracy is "the extent to which the political power of the elite is minimized and that of the non-elite is maximized": C. Tate, "Introduction: Democracy and Law - New Developments in Theory and Analysis" (1997) 49(2) International Social Science Journal 143 at 144, quoting Bollen.

A Place Apart, supra note 15 at $77-141$. 
rather than elitist, political structures; as constitutionalists, we balance our commitment to participation by a concern about the danger of unfettered majoritarianism and thus acknowledge the importance of individual and collective minority rights; and, as pluralists, we accept, respect, and value the radically diverse communities, identities and perspectives that constitute contemporary Canadian society. ${ }^{104}$ These principles will underpin our analysis of various institutional options in Part V and our proposal for the creation of independent Judicial Appointment Commissions in Part VI.

\section{THE CURRENT SITUATION: A DEMOCRATIC DEFICIT}

\section{A. INTRODUCTION}

Numerous changes to the Canadian legal and judicial landscape have occurred over the past thirty years. Legally, the developments of a bill of rights, human rights legislation, and the Charter have altered the nature of litigation and the legal recognition of the equality and dignity of all human persons. Judicially, concerns about political partisanship and impartiality and the increased recognition of judicial independence have resulted in several changes to the judicial appointments process at almost every level in the Canadian court system. Although occurring simultaneously and having similar democratic aims, these paths have rarely crossed or merged.

With the exception of the Supreme Court of Canada, governments have implemented changes in the appointment of judges ostensibly to reduce political or ideological partisanship and to increase "objective," professionally determined, and merit-based appointments to the bench. However, currently, only Ontario and the Yukon have legislated the need for judicial appointments to reflect the population of the province, although the Nova Scotia Advisory Committee and the Alberta Provincial Court Nominating Committee also include "demographics" as a set criterion for assessment. Three other provinces, the Northwest Territories, and the federal appointment process acknowledge the need for representativeness as part of general policy.

Procedures vary from jurisdiction to jurisdiction, most likely due to differing concerns and priorities of the governments involved. Uniformity should not necessarily be an advocated goal, so long as the divergent systems are indicative of the diverse populations in our federalist nation. This section outlines how each jurisdiction currently functions and the results of each selection. The overall pattern we identify is a modification of political partisanship on the basis of greater professionalism. We later argue that while this constitutes an improvement in the process, the democratic commitment to proportionality requires further changes in the system. 


\section{B. METHODOLOGY}

Compared with the United States, there is little documentation or commentary available regarding the current systems of judicial appointment in Canada, especially for the provinces and territories (although the statutes governing s. 92 courts tend to be much more informative). Therefore, to supplement this information, we created a fourpage questionnaire concerning the recruitment, screening, and selection procedure in place, the role of an advisory committee (if present), explicit policies and objectives, as well as a section regarding the demographics of the courts. This questionnaire is reproduced in Appendix I.

During the summer of 1999 , calls were made to every jurisdiction to find a first contact. This was usually to the Deputy Minister of Justice or the Chief Judge of the provincial or territorial court, who then typically forwarded the inquiry to other departments or bodies, such as a provincial judicial council or committee. The exceptions were at the federal level - the Judicial Affairs Secretariat of the Office of the Commissioner for Federal Judicial Affairs was contacted - and in Nova Scotia and Ontario, where the advisory committees were contacted directly. As a follow up, a covering letter and the questionnaire were also sent to each Deputy Minister of Justice and the Chief Judge of every jurisdiction, if they had not been contacted previously to ensure all authorities had an equal opportunity to respond.

Results are gathered from the responses to the questionnaire, governing statutes, and other documentation included with responses, such as application forms, sample advertisements, and committee terms of reference or guidelines. ${ }^{105}$

For ease of review, the different criteria, statutory and otherwise, considered in assessing candidates for appointment are set out in Appendix II, and Appendix III contains the names and positions of those who were kind enough to respond to our questionnaire.

For clarification, committees will be described as "nominating" if it is their function to submit a short-list of qualified candidates to the Minister, or if the governing statute mandates that the Minister recommends only from the qualified list. Committees are described as "screening" if their function is only to assess candidates and all names and assessments are sent to the Minister.

\section{RESUlts}

\section{The DEMographic PRofile of THE CANADIAN JUdiciary}

We inquired into ten different demographic categories: gender, visible minority/race/ colour/ethnic origin, aboriginal origin, disability, age, marital status, religion, sexual

As the information which follows was created by an amalgam of this information, footnotes are not included for each point. However, Appendix III contains the names and position of contacts who provided the information. 
orientation, region, and language. No jurisdiction responded to religion and sexual orientation, usually indicating these were considered irrelevant and no statistics were kept. Region was not particularly significant, as the various statutes define judicial districts and the number of judges in each.

At the federal level, the only information provided was a list of the names of active and supernumerary judges. Upon further inquiry, we were informed that no other information was available. From this list, we were only able to infer the gender representation on the federally appointed courts.

At the provincial and territorial levels, there was a disparate response in that some jurisdictions gave statistics for almost every category, while most only in the gender category. Most likely few, if any, jurisdictions keep formal statistics, but some informants were willing to share the information of which they were personally aware.

The following tables contain a breakdown of the representation of historically underrepresented groups.

\section{TABLE 1: FEDERALly APPOINTED COURTS \& GENDER REPRESENTATION ${ }^{106}$}

\begin{tabular}{|l|c|c|c|c|}
\hline \multicolumn{1}{|c|}{ Federally Appointed Courts } & Male & Female & Total & $\begin{array}{c}\% \text { of } \\
\text { Women }\end{array}$ \\
\hline Supreme Court of Canada & 6 & 3 & 9 & 33.3 \\
\hline Federal Court, Appeal Division & 12 & 1 & 13 & 7.7 \\
\hline Federal Court, Trial Division & 19 & 5 & 24 & 20.8 \\
\hline Tax Court of Canada & 18 & 2 & 20 & 10 \\
\hline Alberta Court of Appeal & 9 & 8 & 17 & 47 \\
\hline Alberta Queen's Bench & 66 & 19 & 85 & 22.4 \\
\hline British Columbia Court of Appeal & 12 & 7 & 19 & 36.8 \\
\hline British Columbia Supreme Court & 79 & 22 & 101 & 21.8 \\
\hline Manitoba Court of Appeal & 7 & 1 & 8 & 12.5 \\
\hline Manitoba Queen's Bench & 30 & 11 & 41 & 26.8 \\
\hline New Brunswick Court of Appeal & 6 & 1 & 7 & 14.3 \\
\hline New Brunswick Queen's Bench & 20 & 5 & 25 & 20 \\
\hline Newfoundland Court of Appeal & 8 & 1 & 9 & 11.1 \\
\hline Newfoundland Supreme Court & 18 & 3 & 21 & 14.3 \\
\hline Nova Scotia Court of Appeal & 7 & 3 & 10 & 30 \\
\hline Nova Scotia Supreme Court & 29 & 8 & 37 & 21.6 \\
\hline Northwest Territories Supreme Court & 2 & 1 & 3 & 33.3 \\
\hline Ontario Court of Appeal & 17 & 5 & 22 & 22.7 \\
\hline Ontario Superior Court of Justice & 226 & 46 & 272 & 16.9 \\
\hline Prince Edward Island Supreme Court, & 3 & 0 & 3 & 0 \\
Appeal Division & & & & \\
\hline
\end{tabular}




\begin{tabular}{|l|c|c|c|c|}
\hline \multicolumn{1}{|c|}{ Federally Appointed Courts } & Male & Female & Total & $\begin{array}{c}\% \text { of } \\
\text { Women }\end{array}$ \\
\hline $\begin{array}{l}\text { Prince Edward Island Supreme Court, } \\
\text { Trial Division }\end{array}$ & 3 & 2 & 5 & 40 \\
\hline Quebec Court of Appeal & 18 & 4 & 22 & 18.1 \\
\hline Quebec Superior Court & 144 & 36 & 180 & 20 \\
\hline Saskatchewan Court of Appeal & 6 & 2 & 8 & 25 \\
\hline Saskatchewan Queen's Bench & 32 & 10 & 42 & 23.8 \\
\hline Yukon Territory Supreme Court & 2 & 0 & 2 & 0 \\
\hline Nunavut Court of Justice & 1 & 1 & 2 & 50 \\
\hline TOTAL & 797 & 206 & 1006 & 20.5 \\
\hline
\end{tabular}

TABLE 2: PROVINCIALly APPOINTED COURTS \& GENDER REPRESENTATION ${ }^{107}$

\begin{tabular}{|l|c|c|c|c|}
\hline Provincially Appointed Courts & Male & Female & Total & $\begin{array}{c}\% \text { of } \\
\text { Women }\end{array}$ \\
\hline Alberta $^{108}$ & 89 & 14 & 103 & 13.6 \\
\hline British Columbia $^{109}$ & 109 & 38 & $\begin{array}{c}140+7 \text { ad } \\
\text { hoc }\end{array}$ & 25.9 \\
\hline Manitoba & 30 & 6 & 36 & 16.7 \\
\hline New Brunswick & 20 & 3 & $23^{110}$ & 13.0 \\
\hline Newfoundland & 21 & 3 & 24 & 12.5 \\
\hline Northwest Territories & 3 & 0 & 3 & 0 \\
\hline Nova Scotia & 19 & 5 & 24 & 20.1 \\
\hline Ontario & 205 & 60 & 265 & 22.6 \\
\hline Prince Edward Island & 2 & 1 & 3 & 33.3 \\
\hline Quebec ${ }^{111}$ & 209 & 51 & 260 & 19.6 \\
\hline Saskatchewan & 35 & 10 & 45 & 22.2 \\
\hline Yukon Territory & 3 & 0 & 3 & 0 \\
\hline TOTAL & 745 & 191 & 936 & 20.4 \\
\hline
\end{tabular}

Demographics are current as of summer 1999, unless otherwise stated.

As of January 1, 1998; Judicial Selection Process Review Committee, Report and Recommendations (Edmonton: Alberta Justice Communications, 1998) at 17. In addition, there are 13 supernumerary judges, one of whom is female.

The statistics were current as of December, 1998; British Columbia, Judicial Council, Annual Report 1996, 1997, 1998 (Victoria: Queen's Printer, 1999) at 4 [hereinafter B.C. Judicial Council]. There were two vacancies at the time of writing so the numbers stem from the make up of the 23 judges then on the bench.

Canadian Law List, 1999 (Aurora, Ontario: Canada Law Book, 1999) at D-439-D-442. The numbers are approximate; gender-neutral names were usually assumed to be male. 


\section{TABle 3: Provincially APPOINTED COURTS AND RePresentation BASED ON CHARACTERISTICS OTHER THAN GENDER}

\begin{tabular}{|c|c|c|c|c|c|c|c|}
\hline $\begin{array}{l}\text { Provincially } \\
\text { Appointed } \\
\text { Courts }\end{array}$ & $\begin{array}{c}\text { Aboriginal } \\
\text { Persons }\end{array}$ & $\begin{array}{l}\text { Visible } \\
\text { Minority }\end{array}$ & $\begin{array}{c}\text { Persons } \\
\text { with a } \\
\text { Disability }\end{array}$ & $\begin{array}{l}\text { Marital } \\
\text { Status }\end{array}$ & Age & $\begin{array}{l}\text { French- } \\
\text { speaking }\end{array}$ & Total \\
\hline Alberta $^{112}$ & 2 & 1 & & & $\begin{array}{l}\text { Average- } \\
46\end{array}$ & & 103 \\
\hline $\begin{array}{l}\text { British } \\
\text { Columbia }^{113}\end{array}$ & & & & & $\begin{array}{l}\text { Average- } \\
43 \text { Range- } \\
40 \text { to } 69\end{array}$ & & $\begin{array}{l}140 \\
+\quad 7 \\
\text { ad } \\
\text { hoc }\end{array}$ \\
\hline Manitoba & & & & & & 3 & 36 \\
\hline $\begin{array}{l}\text { New } \\
\text { Brunswick }\end{array}$ & 1 & 2 & 0 & "varied" & Oldest- 74 & 10 & $25^{114}$ \\
\hline Newfoundland & 1 & 0 & 0 & $\begin{array}{l}22 \\
\text { married, } \\
2 \text { single }\end{array}$ & $\begin{array}{l}\text { Average- } \\
49 \text { to } 50 \\
\text { Range- } 41 \\
\text { to } 58\end{array}$ & $\begin{array}{l}1 \\
\text { bilingual, } \\
4-5 \text { partly } \\
\text { bilingual }\end{array}$ & 24 \\
\hline $\begin{array}{l}\text { Northwest } \\
\text { Territories }\end{array}$ & & $\begin{array}{l}\text { "different } \\
\text { ethnic } \\
\text { origins" }\end{array}$ & & & & & 3 \\
\hline Nova Scotia & & 1 & & & & 2 & 33 \\
\hline Ontario $^{115}$ & 4 & 11 & 0 & & $\begin{array}{l}\text { Average on } \\
\text { appointment } \\
-43.2\end{array}$ & 36 & 250 \\
\hline $\begin{array}{l}\text { Prince Edward } \\
\text { Island }\end{array}$ & & & & & & & 3 \\
\hline Quebec & & & & & & & 260 \\
\hline Saskatchewan & 2 & 0 & 0 & & & 2 & 45 \\
\hline Yukon Territory & & & & & & & 3 \\
\hline
\end{tabular}

The foregoing tables indicate that there is a clear democratic deficit in the Canadian judiciary. The numbers show that only modest improvements have been made in

112 For the category of age, the numbers are accurate as of January 1, 1998. Judicial Selection Process Review Committee, supra note 108 at 17.

113 The statistics were current as of December, 1998; B.C. Judicial Council, supra note 109 at 4.

114 There were two vacancies at the time of writing so the numbers stem from the make up of the 23 judges then on the bench.

115 The breakdown for Visible Minority, Aboriginal Persons and Persons with a Disability is the number of appointments made in each category by the Ontario Judicial Appointments Advisory Committee between 1 January 1989 and 18 June 1999, rather than the actual complement of the court. 
changing the composition of the bench. While there has been some progress in the representation of women, ${ }^{116}$ other historically marginalized groups remain significantly under-represented. However, the identification of a democratic deficit is not, in and of itself, sufficient to justify the need for further changes to the appointment process. All the historically excluded groups continue to be significantly underrepresented. In the next section, we outline the processes that are currently in place that have resulted in the deficit.

\section{APPOINTMENT PROCESSES}

a. Federally Appointed Judges

\section{(i) The Supreme Court of Canada}

The Supreme Court is certainly the most overtly politicized court in Canada as a result of its place at the apex of the judicial hierarchy. However, although a popular topic for criticism and constitutional debate, the Court has experienced the least reform in its appointments procedure. According to the Supreme Court Act, appointments are made by the Governor General in Council, in other words, the federal Cabinet. ${ }^{117}$ The puisne judges of the Court are appointed on the recommendation of the Minister of Justice and the appointment of the Chief Justice is the prerogative of the Prime Minister. ${ }^{18}$ The Minister of Justice normally has one or two special advisors on judicial appointments who accumulate information on potential candidates. Information usually comes from a wide variety of sources, including: the Minister, Members of Parliament, provincial attorneys-general or ministers of justice, the legal profession, judges, and people aspiring to the bench. ${ }^{19}$ There is no formal policy of consultation presently in place. However, in practice, the Minister of Justice, the justice minister from the region or province involved, and the Prime Minister usually consult before a recommendation is made in Cabinet. ${ }^{120}$ Statutorily, at least three members of the court must come from the Quebec bar, or a superior court within the province. ${ }^{121}$ As a matter of convention, normally three judges are selected from Ontario, two from the Western provinces, and one from the Atlantic region. Little else is known about this process.

In 1994, there were approximately 10 percent women; our survey suggests that by 1999 they approximate 20 percent. Our fear is that, absent further reforms, the numbers of women might stall at this percentage.

Supreme Court Act, supra note 78, s. 4(2).

S.I. Bushnell, "The Appointment of Judges to the Supreme Court of Canada: Past, Present, and Future" in Judicial Selection in Canada: Discussion Papers and Reports (Canadian Association of Law Teachers Special Committee on the Appointment of Judges, 1987) at 1.

Canadian Bar Association, Report of the Canadian Bar Association Committee on the Appointment of Judges in Canada (Ottawa: Canadian Bar Association, 1985) at 11 [hereinafter CBA Committee on Appointment].

Ibid. at 12.

Supreme Court Act, supra note 78, s. 6. 
There has been an increase in the amount of public interest in Supreme Court appointments. In recent years, while the government contemplated replacements for the late John Sopinka and the retiring Gérard La Forest, Peter Cory, and former Chief Justice Antonio Lamer, there was extensive media speculation on the appointments. ${ }^{122}$ After each appointee was announced, further coverage was sparked as to the abilities of the individual ${ }^{123}$ and also, with increasing dissatisfaction, as to the legitimacy of the process. ${ }^{124}$ Recently, several provinces have been quite vociferous in complaining about their exclusion from the process. ${ }^{125}$ However, this is still a reactive stance of the public, which has no role in choosing the judges of the highest court in Canada.

The historical demographic of the Court has been largely homogenous. In 1970, former Chief Justice Bora Laskin was the first non-Christian to be appointed to the Court, as well as the first appointee who was not of an English, Scottish, Irish, or French background. ${ }^{126}$ To an extent, it would seem that the Court is slowly becoming increasingly diversified with the appointments of: Bertha Wilson (1982), the first woman on the Court; John Sopinka (1988), the first Ukrainian-Canadian; and Justice Frank Iacobucci, the first Italian-Canadian. With the appointment of Justice Louise Arbour in October 1999, there are now five francophone justices (although she was elevated from the Ontario Court of Appeal and Justice Bastarache is considered an Atlantic-Acadian). Justice Arbour is also the fourth woman to be appointed to the Court. Presently, over one-third of the nine judges are now women. Most recently, Beverley McLachlin was appointed as the first female Chief Justice of the Court.

To illustrate the role that the politics of representation may play in appointments to the Supreme Court, Sidney Sharpe cites an interesting anecdote. While considering Bertha Wilson's appointment in 1982, the federal Cabinet was at odds; then Prime Minister Pierre Trudeau was opposed, whereas the two female Cabinet ministers Begin and Erola supported the move to appoint Wilson. Finally, then Minister of Justice Jean

See e.g. C. McGovern, "Contenders for Supreme Power: a Looming Supreme Court Retirement Spells Opportunity for Two Feminist Judges" Alberta Report $26: 7$ (8 February 1999) 10; J. Geddes, "Chretien's court: insiders battle over a new Supreme Court justice" Maclean's 111:2 (12 January 1998) 16; R. Corelli, "A Phone Call that Changes Everything" Maclean's 110:36 (8 September 1997) 18; S. Fine, "McLachlin Touted to Succeed Lamer" The Globe and Mail (23 August 1999) Al.

See e.g. J. Geddes, "A star for the Supreme Court" Maclean's 112:25 (21 June 1999) 21; "The trouble with Quotas" The Halifax Daily News (10 June 1999) 15; I. Hunter, "In a word, Judge McLachlin is independent" National Post (6 January 2000) A19; K. Makin, "Does She Have the Right Stuff?" The Globe and Mail (26 October 1999) A18.

124 See e.g. G. Gibson, "How to Remove the Judges from the Prime Minister's Grip" The Globe and Mail (13 July 1999) A13; "Public should have a say in judge selection" The Calgary Herald (4 September 1997) A19; Editorial, "Choosing Judges" The Globe and Mail (8 July 1999) A16; R.P. Kerans, "Put a Time Limit on our Judges" The Globe and Mail (I November 1999) A19. J. Ibbitson \& S. Chase, "Ontario Joins Alberta: Rein in Top court" The Globe and Mail (25 October 1999) Al. See also B. Laghi \& K. Lunman, "Justice Minister Defends Process of Nominating Supreme Court Judges: Provinces' Advice Sought in Judicial Appointments, McLellan says" The Globe and Mail (26 October 1999) A4 [hereinafter "Justice Minister Defends"]. 
Chrétien, interjected: "Well boss, the girls are right, I think it's time for a woman, otherwise we'll have problems."127

\section{(ii) Other Section 101 Courts and Section 96 Courts $^{128}$}

Appointments to the Federal Court of Canada, trial and appellate divisions, the Tax Court, and the superior courts of the provinces and territories all follow the same procedure, which the federal government introduced in $1988 .^{129}$ The process is administered by the Office of the Commissioner for Federal Judicial Affairs, from which Personal History Forms may be requested by applicants, or to which interested persons may nominate individuals who will then be invited to apply. The process is continuous, and there is no advertisement when a vacancy occurs. After the Office of the Commissioner receives a completed Personal History Form and authorization form, with the option of a recent photograph, it conducts a preliminary screening of the candidate's technical qualifications (that is, ten years at the bar of a province or territory, or ten years at the bar and the performance of duties and functions of a judicial nature ${ }^{130}$ ) and checks the candidate's standing with the law society. The files are then sent to the appropriate provincial or territorial advisory committee for screening and assessment.

Independent Federal Judicial Appointments Advisory Committees are set up in every jurisdiction, with three regional committees in Ontario and two in Quebec, to screen applicants. The Minister of Justice appoints committee members in consultation with the Commissioner from lists of nominees submitted by certain nominators. The relevant law society, the Canadian Bar Association, and the Chief Justice and the Attorney General of the appropriate province or territory are each entitled to nominate one member (a lawyer, a lawyer, a judge, and a lay person respectively), and the federal Minister appoints three members, two of whom are to be lay members. After assessing the submitted written material, committee members consult both legal and non-legal sources, in addition to the named references. The criteria taken into account when the committee assesses candidates as "highly recommended," "recommended," or "unable to recommend," include: professional competence and experience, personal characteristics, social awareness, and the presence of no potential impediments to appointment. The names and assessments of candidates are then kept on file with the Commissioner for a period of two years, at the end of which candidates are contacted and invited to reapply. In addition, the Minister also consults the Chief Justice and the Attorney General of the province to which the appointment is to be made. If the advice received from these consultations is at odds with the committee's assessment, the

S. Sharpe, The Gilded Ghetto: Women and Political Power in Canada (Toronto: Harper Collins, 1994) at 96-97.

The Nunavut Court of Justice is a single level trial court - there is no separate territorial court staffed by the territorial govermment - and the judges are s. 96 judges, appointed by the federal government.

See Canada, Department of Justice, A New Judicial Appointments Process (Ottawa: Communications and Public Affairs, Department of Justice, 1988).

Judges Act, R.S.C. 1985, c. J-1, s.3; Federal Court Act, R.S.C. 1985, c. F-7, s. 5(5); Tax Court of Canada Act, R.S.C. 1985, c. T-2, s. 4(3). 
Minister maintains the right to request reasons for the assessment or a reassessment. Further, the Minister also retains ultimate responsibility for the appointment and the right to recommend a candidate regardless of her or his assessment by the committee.

Elevations work somewhat differently. Provincial court judges must also apply by completing a Personal History Form. The appropriate committee conducts consultations and makes comments which are submitted to the Minister, but these candidates are not assessed by the members. Provincial court judges are also subject to the Minister's consultations with the Chief Judge, proposed Chief Justice, and the provincial or territorial Attorney General or Minister of Justice. The names are then added to the list of those available for appointment. In contrast, federally appointed judges do not apply, nor are their names submitted to the committees; only the Minister's private consultations are considered.

The Government has stated a "commitment to appoint more women and representatives of Canada's ethnic and cultural minorities to the bench." 131 In furtherance of this objective, the Minister welcomes the advice of "special-interest groups" and advertises the process and invites applications through the legal press and provincial law societies. On the Personal History Form, one has the option to identify oneself as aboriginal, visible minority, ethnicity/cultural origin, or disabled; male/female identification is part of the general information required on the form. However, no formal employment equity policy has been implemented.

In 1990, McCormick and Greene calculated that men comprise about 92.5 percent of superior court justices, ${ }^{132}$ and in 1997, it was estimated that 77 percent of appellate court judges were male. ${ }^{133}$ As of June 1999, approximately 24 percent of the appellate bench, excluding the Supreme Court of Canada, were women and about 21 percent of the federally appointed trial judges were women. ${ }^{134}$ No other information regarding the presence of minorities on the bench was provided in response to our survey. However, according to Greene et al., in 1997, about 90 percent of appellate judges selfidentified as Canadian, French, English, Irish, or Scottish; 4 percent said they were Jewish; and only 6 percent self-identified as members of one or more recent ethnic groups to arrive in Canada. ${ }^{135}$

Supra note 129 at 9.

McCormick \& Greene, supra note 99 at 62.

Greene et al., supra note 67 at 25.

Approximately 155 women compared with 794 men in total, or about 20.5 percent. Canada, Federal Judicial Affairs, Active and Supernumerary Judges (Ottawa: June 22, 1999) [unpublished]. Statistics are approximate. The Federal Judicial Affairs Secretariat provided the authors with a list of judges at each level of court and gender neutral names were usually assumed to be male.

Greene et al., supra note 67 at 33 . This number does not give a breakdown of those persons who may be part of a "visible" minority group. 


\section{b. Provincially Appointed Judges}

\section{(i) British Columbia}

Appointments to the British Columbia provincial court are formally made by the Lieutenant Governor in Council, on the advice of the Minister of Justice. However, the Minister is assisted by the Judicial Council of British Columbia, which recruits, screens, and nominates qualified candidates.

Like the federal process, the procedure is continuous and no advertisements are made when a vacancy occurs. When a vacancy occurs, the Chief Judge submits a list of names selected from the approved pool to the Attorney General. Although the Attorney General may request to see all names on file, s. 6(1) of the Provincial Court Act implicitly requires the appointee be an individual recommended by the Council. ${ }^{136}$ One applies directly to the Judicial Council by submitting a Judicial Candidate Information Summary Form, along with a medical certificate and recent photograph. The council consults the references named by the candidate, the judges before whom the candidate has appeared, and reports from the Law Society and the Canadian Bar Association. At times, private consultations may also take place with others familiar with the applicant. If the candidate satisfies these steps, she or he is then contacted for an interview by a quorum of the council. If the applicant is not interviewed, she or he ceases to remain a candidate for appointment. After the interview, a majority vote is taken, by which the council determines the acceptability of the interviewee. Assessments are kept on file for three years, and if an applicant has not received an offer for a judgeship from the Attorney General during that period, she or he must reapply.

The council is composed of a maximum of nine members:

- the Chief Judge as the presiding member;

- an Associate Chief Judge;

- the treasurer of the Law Society of British Columbia (or her or his nominee);

- the president of the British Columbia branch of the Canadian Bar Association (or someone nominated by her or him);

- $\quad$ a judge appointed by the Lieutenant Governor in Council; ${ }^{137}$

- not more than four others appointed by the Lieutenant Governor in Council. ${ }^{138}$

The Judicial Council, like other provincial councils and the Canadian Judicial Council, is also responsible for the discipline of judges; however, only in British Columbia,

Provincial Court Act, R.S.B.C. 1996, c. 379, s. 6(1): "On the recommendation of the council, the Lieutenant Governor in Council ... may appoint judges..." [emphasis added].

137 This office has usually been filled by the president of the Provincial Court Judges' Association, who is elected annually.

138 The lay member has traditionally been a justice of the peace. 
Saskatchewan, Newfoundland, and the Yukon are the Councils responsible for advising government on appointments. ${ }^{139}$

According to the 1998 Annual Report of the British Columbia Judicial Council, relatively few applications are received from aboriginal persons or other visible minorities. ${ }^{140}$ The Council does encourage such applications through meetings with the bar and the Chief Judge will discuss the issue of representativeness of the bench at meetings, seminars or media interviews. Although there has been an improvement as regards to gender, ${ }^{141}$ the Judicial Candidate Information Summary form has only provided the option to identify as visible minority, aboriginal, disabled, ethnicity/cultural origin, or other, as of 1999. Consequently, no statistics are yet available on these matters.

\section{(ii) Alberta}

In early 1999, Alberta Justice implemented a new nominating procedure for judicial appointments following the report of the Judicial Selection Process Review Committee (1998). There are many steps in this process. Firstly, it is continuous, and applicants request Judicial Candidate Information Summary forms from the Assistant Deputy Minister. The Summary, with a Disclosure of Information form and a Consent to a Criminal Record Check form, is forwarded to the Provincial Judicial Council for processing after the Assistant Deputy Minister completes the criminal record check. The Council consults with references and the Law Society, interviews applicants, and then notifies the Minister as to its recommendation (i.e., Approved/Not Approved). The names of approved candidates are maintained by the department for three years so that, at any given time, there is a pool of candidates.

When a vacancy arises, and after the Chief Judge consults with the Minister, the Provincial Court Nominating Committee is convened. The Committee interviews candidates at its discretion from the list of approved applicants compiled by the Judicial Council. It will then provide a short-list of three to six names to the Minister. The Minister is required to recommend from this list, but has one opportunity to request a fresh list of candidates. If the list contains less than six names, the Committee must certify that no other candidates were qualified.

The Judicial Council has a maximum of six members who are either designated by virtue of their office, or appointed:

- the Chief Justice of Alberta or a designated judge from the Court of Appeal;

- the Chief Justice of the Queen's Bench or a designated Queen's Bench judge;

Alberta created a new advisory body at the beginning of 1999 to take over the appointments function previously performed by the Alberta Judicial Council.

140 British Columbia, Judicial Council of British Columbia, Annual Report (Victoria: Queen's Printer, 1999) at 6.

141 At the end of 1998, 38 of 140 full-time and seven ad hoc judges on the Provincial Court were women. The male and female judges were the same age range (40-69) and the average age was 43, but the median for female judges was 42 as compared to 47 for male judges: $i b i d$. at 4 . 
- the Chief Judge or a designate of the Provincial Court;

- the President of the Law Society of Alberta or a designate;

- not more than two persons appointed by the Minister of Justice.

Like other provincial Judicial Councils, Alberta's Council has responsibilities beyond appointments, for example, judicial discipline and the formulation of a judicial code of ethics. It was these functions that motivated the Government's decision to maintain a role for the Council in appointments when instituting the recommendations of the Review Committee. However, "because the management function of searching for the best appointees and the semi-judicial function of conducting discipline proceedings are different," the Provincial Court Nominating Committee was also established. ${ }^{142}$ The Committee has six lay members, appointed by the Minister, and two members of the legal profession, appointed by the Minister after consultation with the Law Society. Although there is no formal policy regarding the representativeness of the Committee or the Council, in the summer of 1999, there were two female members and one Aboriginal member.

The establishment of the Alberta Committee included the adoption of the criteria of the Ontario Judicial Appointments Advisory Committee, including the criterion of a "reasonably representative" provincial judiciary. However, it is too early to assess the effect of this new policy. As of 1 January 1998, 14 of Alberta's 103 provincial court judges were women; one of its 13 supernumerary judges is female.

\section{(iii) Saskatchewan}

Like British Columbia, Saskatchewan also uses the provincial Judicial Council as an advisory body for appointments. However, the responsibility of the Council in regard to appointments is strictly advisory; in other words, the Council fields applications and screens candidates, but all names and assessments are forwarded to the Minister of Justice for consideration and no short list is created. The Minister selects a name and recommends the candidate to the Lieutenant Governor in Council.

The process is continuous and no advertisement is made when a vacancy arises. An interested individual must submit a completed Judicial Candidate Information Form, release of information forms for the Law Society and the RCMP, three letters of reference, and a photograph directly to the Judicial Council. The Council secretary arranges the reports from the Law Society and RCMP, and the members consult the legal community and lay people familiar with the candidate as to the individual's qualifications. The application is then discussed at a meeting of the full council, and the candidate is given a rating of "not approved," "good," "very good," or "excellent."143 The Minister is informed of the rating assigned to each candidate, and, when a vacancy occurs, the appointment is made by an Order in Council. Approved 
candidates ("good" and above) remain on file for three years and are encouraged to reapply if they have not been appointed during that time.

There are eight members on the Council:

- $\quad$ the Chief Justice of the province;

- the Chief Justice of the Queen's Bench;

- the Chief Judge of the Provincial Court;

- two other Provincial Court judges elected at a meeting of the court en banc;

- the President of the Law Society;

- two lay people appointed by the Lieutenant Governor in Council after consultations between the Minister, the Chief Justice, and the Chief Judge.

It is through these two lay appointments that representation of historically marginalized groups is usually fulfilled on the Council.

Although there is no official policy regarding the appointment of members of historically excluded groups, the practice of the Council has been to give special consideration to these applications. In the past ten years, there has been an increase in applications by females and approximately fifty percent of the appointments have been women. All of the aboriginal candidates that have been approved by the Council have been appointed, but the number of aboriginal lawyers with ten years at the $\operatorname{bar}^{144}$ is still very small. There are currently ten women and two aboriginal persons on the fortyfive member bench of the Saskatchewan Provincial Court.

\section{(iv) Manitoba}

The Minister of Justice recommends appointments to Cabinet when a vacancy arises on the Provincial Court. However, s. 3.1(1) of the Manitoba Provincial Court Act ${ }^{145}$ mandates:

3.1(1) An appointment ... shall be made from a list of candidates that is recommended by a nominating committee....

Therefore, unlike the federal or Saskatchewan process, the Manitoba Judicial Nominating Committee actually engages in the process of nominating candidates rather than merely screening or recommending.

The process is vacancy-driven in that, upon a vacancy, the Minister advises the Chief Judge that an appointment is to be made, and the Chief Judge then convenes the Judicial Nominating Committee. The Committee advertises the vacancy in local newspapers, the Law Society and Manitoba Bar Association newsletters, and on a Notice to the Profession which is posted at the relevant court house. If a bilingual judge is required, the advertisement will also be published in the francophone media. Word 
of mouth advertising is also seen as an important part of the recruiting process. The Judicial Candidate Information Form is submitted directly to the Committee, with an authorization for release of information. After checking with the Law Society and suggested references, interviews are conducted by a full panel of the Committee. The Committee then provides the Minister with an unranked list of three to six qualified candidates. The only instance where the Minister may request a new name for the list is if the chosen appointee is unwilling or unable to accept an appointment, in which case the Committee would submit a new name or may conduct a new advertising and screening process. The appointment is final when an Order-in-Council is passed.

The seven members of the Committee are appointed and designated anew each time the Committee is convened to recommend an appointment. It is composed of:

- the Chief Judge as chair;

- a judge designated by the judges of the Provincial Court;

- a person designated by the President of the Law Society;

- a person designated by the Manitoba branch of the Canadian Bar Association;

- three lay people appointed by the Lieutenant Governor in Council.

There is no public policy regarding the representation of historically excluded groups on the bench, although the government has at times, through Orders-in-Council, directed that a particular appointee should be bilingual or a resident of a particular region of the province. There are presently three bilingual judges on the bench. Despite the lack of formal policy or initiatives, there has been a notable improvement in the appointment of women over the last ten years. All the female judges on the bench, including Canada's first female Chief Justice, were appointed between 1988-1994: three in 1994, two in 1988, and one in the intervening time, for a total of six.

Ontario

The constitution of Ontario Judicial Appointments Advisory Committee was one of the first comprehensive changes to the judicial appointments system in Canada. Its functions are statutorily mandated, including recruitment, screening, and nomination. The statute also mandates that the bench and the Committee should both reflect the diversity of the society of Ontario. ${ }^{146}$ Further, it is required that the "Attorney General shall recommend to the Lieutenant Governor in Council ... only a candidate who has been recommended for that vacancy by the Committee...." 147

When a vacancy arises, the Committee advertises in the Ontario Reports and sends advance notices to 160 legal and non-legal associations. Members will also attend association meetings upon request to discuss the process. Applicants submit their Judicial Candidate Information Form and their security and information release forms directly to the Committee. A selection process occurs after Law Society and criminal records are checked, and references and consultations are made; a full panel of the 
Committee then interviews suitable candidates and a vote is taken after each interview. Finally, the Committee submits a ranked list of not less than two names to the Minister, who may reject the list and request a fresh one.

There are thirteen members on the Judicial Appointments Advisory Committee, including:

- two provincial judges appointed by the Chief Judge;

- $\quad$ one lawyer appointed by the Law Society of Upper Canada;

- one lawyer appointed by the Ontario branch of the Canadian Bar Association;

- one lawyer appointed by the County and District Law Presidents' Association;

- one member of the Ontario Judicial Council appointed by it;

- seven lay persons appointed by the Attorney General.

The Courts of Justice Act acknowledges the need for the Committee to reflect the linguistic duality, diversity, and gender balance of Ontario, which has usually been achieved through the lay appointments. ${ }^{148}$ For example, in 1997, there were eight men and five women from all regions of the province; and in June 1999, the Committee included a black woman, an Aboriginal woman, a bilingual man, as well as an Italian man and an Italian woman.

Both the statute and the Committee guidelines recognize the desirability of increased diversity in judicial appointments. The comprehensive list of criteria used to evaluate candidates includes professional excellence, community awareness, personal characteristics, and demographics. As put by the Committee in a recent annual report, the last requirement means that

[t]he provincial judiciary should be reasonably representative of the population it serves. This requires overcoming the serious under-representation in the judicial complement of women, visible, cultural, and racial minorities and persons with a disability. ${ }^{149}$

The Committee has firmly accepted outreach as one of its goals and endeavours to communicate with all eligible candidates from the various under-represented sections of the legal community. In addition to the advance notices sent to various associations, advertisements specifically encourage individuals from under-represented groups to apply, and the application forms ask candidates to self-identify. ${ }^{150}$ However, like some other jurisdictions, ten years at the bar is a qualification for appointment, ${ }^{151}$ and unfortunately, this precludes the consideration of many lawyers from minority groups.

143 Ibid., s. 43(3), as am. by S.O. 1994, c. 12, s. 16.

149 Ontario, The Judicial Appointments Advisory Committee, Anmual Report for the Period from 1 January 1997 to 31 December 1997 (Toronto: The Judicial Appointments Advisory Committee, 1998) at 11-12 [hereinafter Ontario Judicial Committee].

150 See also Canadian Bar Association Task Force on Gender Equality in the Legal Profession, Touchstones for Change: Equality, Diversity and Accountability (Ottawa: Canadian Bar Association, 1993) at 187-88 [hereinafter Touchstones for Change], describing the proactive measures taken by the Committee in recruiting women lawyers and encouraging their applications. 
Recently though, the Attorney General has asked the Committee to increase the size of the short list to include more candidates with diverse backgrounds. ${ }^{152}$ As a result, there has been an increase in the number of interviews and an increase in the number of recommended individuals from which the Attorney General may choose. There are currently 60 women on the 265-judge bench of the Ontario Provincial Court.

\section{(vi) Quebec}

The appointment process in Quebec resembles the federal process in that recruitment is conducted by an administrator independent of the committee. However, Quebec established its procedure almost a decade earlier. A significant difference is that the advisory committee in Quebec has the power to nominate candidates to Cabinet rather than merely to screen them as in the federal process. ${ }^{153}$

Once a vacancy occurs, it is incumbent upon the Minister to advertise the opening in the journal of the Barreau du Quebec or a national, regional, or local newspaper. The advertisement must include the court, district, and date of the vacancy. Applicants then submit a recent photograph and curriculum vitae to the co-ordinator (an individual designated by the Minister) with the following information: name, address, telephone number, date of birth, date of admission to the Bar, proof of entry on the roll of the Barreau du Quebec and to which section she or he belongs, number of years of practice, areas of legal practice, other information as to pertinent professional activities if the applicant has not practised for ten years, information about any disciplinary decision rendered, the name of employers over the past ten years, the court and position for which the candidacy is submitted, and a statement summarizing one's reasons for wishing to be appointed as a judge. The government regulation deems the candidate to have authorized a Bar and criminal investigation by the co-ordinator, and, once this is completed, the file is sent to the Selection Committee.

The Committee reviews the files, calls each candidate to an interview, and assesses the experience and personal and intellectual qualities of the candidate. The Committee then submits to the Minister a report containing the names of individuals it considers fit for appointment, with any comments it deems advisable or any reasons which the Committee may have to doubt the state of health of the candidate. If the Minister feels she or he cannot, "in the best interest of justice," recommend from the list, then another advertisement will occur and the process will be repeated.

The Committee is composed of three individuals appointed by the Minister, namely:

- one judge of the court where there is a vacancy, appointed on the recommendation of the Chief Judge of that court;

- $\quad$ one advocate appointed after consultation with the Barreau du Quebec;

- one lay person.

152 H. Cooper, answers to questionnaire [unpublished, on file with authors].

153 See Regulation respecting the procedure for the selection of persons apt for appointment as judges, R.R.Q. 1981, c. T-16, r. 5 [hereinafter Regulation]. 
The committees in the judicial districts of Montreal and Quebec are appointed on the first day of January each year, whereas the other selection committees convene only when a vacancy arises.

There is no articulated policy regarding representation on the Committee, or in relation to appointments or nominations. Currently, approximately 20 percent of the 270 -judge bench is composed of women.

\section{(vii) New Brunswick}

New Brunswick's appointment structure is unique. Applications are filtered through three different bodies before the Minister makes a recommendation to the Cabinet. The process is continuous in that applications may be submitted at any time and no advertisements are made upon a vacancy. The Deputy Minister of Justice acts as the administrator, and receives all applications and maintains the records of all candidates. ${ }^{154}$ Along with the Standard Information Form, an applicant also submits a recent photograph and an authorization and release of information form; a medical certificate may also be required at a later date. After the Deputy Minister checks the statutory qualifications, ${ }^{155}$ the files are sent individually to the nine Review Advisors for screening and assessment.

Upon review of the written material and after making private consultations, each Review Advisor classifies the candidates as "acceptable," "highly acceptable," or "otherwise." The Deputy Minister then tabulates this information and prospective appointees are subsequently assessed by an Interview Committee, which classifies candidates in the same manner as the Advisors. The Deputy Minister retains all files for a period of three years, and if a candidate has not received an offer for a judgeship during that time, she or he may reapply. The Minister chooses from the list of qualified candidates when a vacancy arises, but maintains the right to request a reassessment if the Minister's own consultations have resulted in information about a candidate which is at odds with the Committee's assessment. Before making a recommendation to the Lieutenant Governor in Council, the Minister also conducts her or his own consultations with the legal profession, the judiciary, and other sectors of New Brunswick society, such as "special interest groups" and other "informed individuals."

There are a total of nine Review Advisors, nominated and representative of the bench, the bar, and New Brunswick society. They include:

- $\quad$ one nominee of the Law Society;

- one nominee of the New Brunswick branch of the Canadian Bar Association;

- one nominee of the Association des juristes d'expression française du NouveauBrunswick;

154 The Deputy Minister acts in a fashion similar to the Commissioner of Federal Judicial Affairs at the federal level or the co-ordinator in Quebec.

iss An Act to Amend the Provincial Court Act, S.N.B. 1987, c. 45, s. 3. The statutory qualifications are ten years of good standing at the bar of a province. 
- $\quad$ one puisne judge of the Queen's Bench nominated by the Chief Justice of that court;

- $\quad$ one puisne judge of the Court of Appeal nominated by the Chief Justice of New Brunswick;

- $\quad$ one puisne judge of the Provincial Court nominated by the Provincial Court Judges' Association;

- $\quad$ one nominee of the New Brunswick Criminal Defence Lawyers' Association;

- two lay persons nominated by the Minister of Justice who are "capable of representing the public interest." 156

The Interview Committee is composed of the present or former Chief Justice of the province, the Chief Judge or Associate Chief Judge of the Provincial Court, and one of the lay Review Advisors mentioned above.

There are no policies in place regarding the representation of minority groups in the Committee or in the appointment process. However, New Brunswick is the only jurisdiction that specifically includes the participation of a francophone association as part of its review procedure. Perhaps as a result, there are eight francophone judges and ten individuals who are fully bilingual. Of the twenty-five judges of the Provincial Court, three are women, two are visible minority persons, and one is aboriginal.

(viii) Nova Scotia

The Nova Scotia Advisory Committee on Judicial Appointments offers a thorough description of its recruiting, screening, and nominating process in its "Guidelines to Ensure Appointments Based on Merit." 157 However, the Provincial Court Act does not mention the Committee at all. ${ }^{158}$

The process begins with a vacancy on the Provincial Court, at which time the Committee convenes and advertises the position throughout the province, as well as in a national legal publication if it so decides. An applicant must submit, directly to the Secretary of the Advisory Committee, nine copies of the application form, and has the option of including a resumé of not more than two pages. After considering the written material, conducting a criminal check, and possibly contacting references, the Committee interviews applicants at its discretion. Notes are made regarding strengths and weaknesses of the candidate, and an unranked short-list of three to six names is compiled with a précis of information on each. This list is submitted to the Minister who recommends the appointment to the Lieutenant Governor in Council. If the Minister's information is at variance with that of the Committee's, a reassessment may be requested.

The Committee is composed of eight members:

New Brunswick, Department of Justice, The Judicial Appointments' Review and Consultation Process (received: July 7,1999$)$ [unpublished, on file with authors].

Nova Scotia Guidelines.

Judges of the Provincial Court Act, R.S.N.S. 1989, c. 238. 
- the Chief Judge of the Provincial Court or her or his appointee;

- the Chief Judge of the Family Court or her or his appointee;

- two lawyers appointed by the Bar Council;

- four lay persons appointed by the Minister of Justice.

The lay members are appointed with the following considerations in mind: geographical representation, gender balance, minority representation, and representation of persons with a disability. According to the Advisory Committee, considerable effort is made to ensure that representativeness is achieved.

"Demographics" is listed as one of the criteria used by the Committee in assessing candidates. After the categories of Minimum Qualifications, Personal Characteristics, Intellectual and Judgmental Ability, Professional Excellence, and Community Awareness and Understanding, the guidelines set out the following description:

\begin{abstract}
The provincial judiciary should be reasonably representative of the population it serves. This requires overcoming the serious under-representation of women and minorities. The Committee will recommend the appointment of a well qualified person from an under-represented group if no one else is clearly better qualified.
\end{abstract}

As well, it is essential for the provincial judiciary to reflect the bilingual nature of the province. ${ }^{159}$

Further, the advertisement also includes a statement encouraging applications from individuals from under-represented groups. However, there is no place on the application form itself to allow an applicant to identify as being a member of a minority group. Currently, there are five (caucasian) women, one black woman, and one black man on a bench of $24 .{ }^{160}$

\title{
(ix) Prince Edward Island
}

When a vacancy on the Provincial Court occurs in Prince Edward Island, the Secretary of the Law Society advertises the position through the Prince Edward Island Law Society. Word of mouth is also considered very important, due to the vacancydriven process and the small size of the provincial bar. Applicants then submit a Judicial Candidate Information Form, Authorization for Disclosure of Information Form, a Security Release Form, and a Certificate of Standing from the Law Society directly to the Judicial Appointments Advisory Committee. Interviews are considered unnecessary because of the small bar, especially in the area of criminal law expertise, which is the only jurisdiction of the Provincial Court. The Committee assesses candidates on the categories of "highly recommended," "recommended," and "unable to recommend," with reasons for each assessment. The assessments are then forwarded to the Attorney General, who recommends the appointment to Cabinet.

159 Nova Scotia Guidelines, supra note 157.

160 These numbers do not match up with the statistics returned from the province, because we have included Judge Connie Sparks who is currently a part-time member of the Provincial Court (Family Division). 
The Committee consists of five members:

- the Chief Judge of the Provincial Court as chair;

- a lawyer appointed by the Law Society;

- a lawyer appointed by the Prince Edward Island branch of the Canadian Bar Association;

- two lay members appointed by the Attorney General, who, "by virtue of their education and employment can properly assess the qualities required of a provincial court judge." 161

The Committee's terms of reference mandate that "in the appointment of members [of the Committee], diversity of population and gender balance shall be recognized."162

Although there is no similar policy in regard to the appointment of judges, the Judicial Candidate Information Form covering letter does encourage applicants to identify as a member of a traditionally under-represented group, if they so wish. However, there is no specified place on the form to do so. Of the three-judge bench, one is currently a woman. Due to the small size and rarity of appointments, it is impossible, at this time, to determine what role the need for representation plays in this process.

\section{(x) Newfoundland}

The Newfoundland procedure is also vacancy-driven. The Chief Judge's office advertises in two local daily newspapers (the Western Star and St. John's Evening Telegram), on the Law Society bulletin board and in its library, as well as in the Law Society newsletter if it coincides with the timing of the vacancy. For administrative purposes, the Candidate Information Form, Medical Record, and Consent for Release of Medical Information are sent by the applicant to the Secretary of the Chief Judge, who compiles the applications and forwards them to the Judicial Council.

Private consultations are conducted by the Council members with the Law Society, members of the bar and judges familiar with the candidate. Every candidate receives a half-hour interview by a full panel of the Council. After the interview, applicants are rated as "highly recommended," "recommended," or "unable to recommend at this time"; they are also ranked in order of the Council's preference. The chairperson then submits a report to the Minister of Justice which includes the assessments of all candidates; there is no short list. However, the statute does mandate that "[n]o person may be recommended by the minister ... without the recommendation of the judicial council."163 Unsuccessful candidates are kept on file for two years, but must notify the Council by letter of their interest each time a vacancy arises. The Council reports July 5,1999 ) [unpublished, on file with authors].

Ibid.

163 Provincial Court Act, 1991, S.N. 1991, c. 15, s. 5(3).
} 
that it is very satisfied with the process, and appointees have always been chosen from the top category since the Council began its advisory role.

The Council has six members who are designated by virtue of their office or appointed by the Lieutenant Governor in Council after being nominated by various authorities. They include:

- a justice of the Supreme Court as chairperson, who is nominated by the Chief Justice of the Trial Division;

- a bencher nominated by the Law Society;

- two lay persons nominated by the Minister of Justice;

- the President of the Newfoundland Provincial Judges' Association;

- the Chief Judge of the Provincial Court.

The lay positions have usually been filled by individuals with a variety of employment backgrounds, including a physiotherapist, an entertainer and singer, and the owner of a plumbing firm. There is no formal policy regarding the representativeness of the Council; there is usually at least one woman, but this has not been deliberate.

There is also no policy in place regarding the representation of groups in appointments to the bench. "Objective" assessment is seen as the main priority and no particular consideration is given to applicants from under-represented groups. There are presently three women on the bench of 24 judges. There is also one judge of Inuit origin. However, he was appointed about twenty years ago, before the current appointment process was implemented. The Council considers the bench to be generally reflective of the provincial population, which is seen to be itself largely homogenous.

\section{(xi) Northwest Territories}

The Northwest Territories amended its Territorial Court Act in late 1998 to include the new nominating role played by the Judicial Appointments Advisory Committee. ${ }^{164}$ As a result, many of the details have yet to be finalized, and no appointments have arisen to allow the Committee to exercise its new jurisdiction at the time of writing. In fact, there has not been a new appointment in over ten years. Therefore, although the new process is quite comprehensive, it is too early to analyze its impact on the goal of representation on the bench.

The process begins with a vacancy, at which time advertisements are placed in major newspapers across Canada and with each Law Society. Applicants then send their curriculum vitae, three references, and a letter expressing their interest to the Judicial Appointments Advisory Committee. Based on the previous process, since the Committee has not yet established a defined procedure, applications will be reviewed and selected candidates will be interviewed and asked the same set of questions. A ranked list of candidates, with brief supporting reasons, is then submitted to the 
Commissioner in Executive Council, from which the Commissioner must recommend an appointee. ${ }^{165}$

The Committee is composed of:

- the Chief Judge of the Territorial Court;

- the next most senior territorial judge;

- two members of the Law Society appointed by it;

- four lay members appointed by the Commissioner.

The two judges are designated by virtue of their office, but in appointing the other six, the statute mandates recognition of the importance of reflecting the diversity of the population and the gender balance of the Territories. The Committee is responsible for recruiting, screening, and nominating candidates for appointment, but as mentioned above, it has not yet had the opportunity to do so. In consequence, it remains uncertain what effect this new process will have on the demographic of the court. Currently, there are three male judges on the court of "different ethnic origins." Before the division of the Territories on 1 April 1999, there was one female judge, but Justice Beverley Browne has since become the Senior Justice of the Nunavut Court of Justice.

\section{(xii) Yukon Territory}

Yukon's new Territorial Court Act ${ }^{166}$ parallels, and perhaps surpasses, the comprehensiveness of the Ontario legislation in its guidelines for appointments. Like the Northwest Territories legislation, under s. 8, the Minister of Justice is required to recommend appointees from the short list provided by the Judicial Council of the Territorial Court, and no provisions are included allowing a rejection of the list or a request for reassessment. Further, representativeness in appointing Council members and judges is also legislated.

When a vacancy on the court arises, the Council advertises in The Globe and Mail, National Post, full-run editions of Lawyer's Weekly, and local newspapers. Notices are also sent to each provincial Law Society and Provincial Judges' Association. Judicial Candidate Information Forms and Release of Information Forms are sent to the Judicial Council directly. After reviewing applications, and consulting references and relevant members of the legal community, the Council shortlists and interviews selected candidates. If applicants are shortlisted, they are required to authorize a criminal records check and may be required to submit to a medical examination. This short list includes three to eight unranked names, which the Minister must choose from in making her or his recommendation to the Commissioner in Executive Council.

The Council is composed of eight or nine members appointed by the Commissioner in Executive Council: 
two nominees of the Minister, one of whom shall be a member of the Law Society and the other shall be a lay person; two nominees of the Yukon First Nations, one of whom shall be a lay person;

- one lawyer nominated by the Law Society;

- $\quad$ one nominee of the Chief Judge;

- $\quad$ one nominee of the justices;

- $\quad$ one resident judge of the Supreme Court nominated by the Senior Judge;

- one lay person who may be nominated at the discretion of the Council.

Lay membership is to be reflective of the diversity and demographics of the Yukon. Including Yukon First Nations as a nominator is an innovative anomaly in the Canadian appointments system. No other jurisdiction allows for the direct inclusion of groups not explicitly representing legal or judicial interests.

The statute and Council guidelines also recognize the need to have "a bench which is demographically representative of the community it serves," 167 and this is included as a criterion for appointment. The Judicial Council also encourages applications from female candidates and members of other visible minorities on the Candidate Information Form, although there is no specified place to identify on the form itself. Unfortunately, no statistics were provided to examine the effect of these policies on the composition of the Territorial Court.

\section{(xiii) Nunavut Territory}

Nunavut became Canada's third territory on April 1, 1999. With its establishment, a new justice system was also put in place. The single level trial court, the Nunavut Court of Justice, is composed of s. 96 judges. In other words, the judges of the court are appointed by the federal government under s. 96 of the Constitution Act, 1867 pursuant to the system outlined above. ${ }^{168}$

Territorial Court Act, S.Y.T. 1998, c. 26, s. 9(c)(i).

In addition, there are other options being explored with the dual function of minimizing longdistance justice and closing cultural gaps between the traditional English common law system and the people of Nunavut - approximately 85 percent of the territory is Inuit. Community justice councils, composed of elders and community members, are a possible method of passing judgment on those who admit their guilt under a system of diversion programs. Justices of the Peace will also play an important role in the communities as resident representatives of the justice system. There were 26 female and 56 male Justices of the Peace undergoing extensive training in February, 1999. Community Justice Committees are also being developed for every community and "[s]trong links have been forged between the RCMP and these Community Justice Committees to encourage communication and (maximized) diversion," as well as Family Group Conferencing training to facilitate peaceful conciliation (J. Middlemiss, "Nunavut: The Midnight Sun Rises on a New Justice System" (1999) 8:4 National 28 at 30). The commitment of judicial officials involved in the new system is also integral to its success. For example, Madam Justice Beverley Browne "has dedicated herself to educating [Nunavut's] court officials, lawyers, Justices of the Peace, and Community Justice Committees, and also took the step of involving our Community groups in her court." ( $R$ Williams, Speaking notes for a presentation regarding Bill C-57 (February 11, 1999) [unpublished].) 


\section{COMPARISONS}

As is obvious from the foregoing discussion, with the sole exception of appointments to the Supreme Court of Canada every jurisdiction in Canada benefits from the use of an advisory committee in the judicial appointment process. While broadly similar, and although each has the goal of creating greater independence and transparency in the process, none of the systems is identical. This section attempts to draw out some of these differences and makes a preliminary effort at analyzing the possible effects these distinctions might have on creating a proportionately representative judiciary. ${ }^{169}$ Solutions are not addressed in this part; however, it should be kept in mind that one aspect of the process does not break or make an effective system, and that broadlybased changes may be needed.

\section{THE PROCESS}

There may be a variety of reasons why a jurisdiction would choose to adopt a vacancy-driven process over a continuous one. For example, the Prince Edward Island Provincial Court has only three judges on the bench; consequently, vacancies will occur relatively rarely, and the small size of the bar also means there are relatively few applications. A permanent committee that continuously reviews candidates is not required for practical reasons. Nova Scotia, Newfoundland, and the Yukon and Northwest Territories may also have vacancy-driven processes for purposes of efficiency; conversely, this could be the reason why the larger bars and benches in British Columbia, Alberta, Saskatchewan, and in the federal process may require a continuous recruitment. Lastly, although anomalous at first glance, the vacancy-driven processes of Ontario and Quebec, the provinces with the largest provincial courts, are also reasonable since both have regional committees in place within the province. How then, is the nature of the process pertinent to our discussion?

First, whether the process begins with a vacancy on the bench or not, determines, in most jurisdictions, whether or not the positions are advertised and, as a corollary, whether members of the bar are given immediate notice that they may apply. Obviously, persons consciously interested in a judicial position could discover for themselves the proper contact in order to apply, and this is made easier with the right network. However, such a process avoids both the ideals of transparency and accountability, and undervalues the importance of proactive recruitment. If the purpose is to receive as many applications from interested individuals as possible, including those from a broad cross-section of the bar, then expecting candidates to discover the process through the legal grapevine does little to change the appointments system. Further, to say that if an individual were truly interested, then she or he would make the effort to find out how to apply for a judicial position is also inadequate. The proactive measures in recruiting applications from female lawyers taken by the Ontario Advisory Committee on Judicial Appointments in 1991 are a case in point. The

169 Political patronage, though still a concern for the process of appointments, is not the focus of this analysis. Openness and representation are the more contemporary concerns we would like to address. 
Committee wrote to association presidents and every female lawyer with the statutory qualifications, ${ }^{170}$ resulting in 18 female appointees between 1 November 1990 and 30 June 1992, numbers that have since dropped considerably. ${ }^{171}$

However, there is no apparent causal connection between the nature of the process and the number of members from under-represented groups on the bench. For example, even though the size of the courts are almost the same in New Brunswick and Newfoundland and each uses a different process, the number of women on the bench is exactly the same. Most jurisdictions remain relatively constant in their gender distribution (between 20-27 percent) regardless of the process used or presence of advertising. ${ }^{172}$ Of the statistics returned, Ontario and New Brunswick have the greatest complement of Aboriginal and visible minority judges, yet each uses a different process of recruitment. As a result of the Ontario experience, perhaps the question to be addressed is not whether positions should be advertised, but how positions are advertised.

Another interesting aspect of the process is the application form that each candidate must complete. Regardless of whether the jurisdiction encourages identification by applicants as to their status as a member of an under-represented group, not all application forms have a section devoted to giving the applicant such an opportunity. Only British Columbia and the Federal Judicial Affairs application forms specifically provide for this identification. Granted, this information may be gleaned from other aspects of the application process, such as languages spoken or by the photographs requested in some jurisdictions (e.g. Quebec and New Brunswick). However, these methods seem adverse to a goal of representativeness or equal opportunity - they could be unreliable, and they do not give the candidate a choice to identify. Similarly, encouraging identification, yet not providing a space for it, also seems problematic. Perhaps an individual from a historically marginalized group would prefer not to highlight her or his "difference" under a random section of the form when this is not required of other applicants. It is yet another inadvertent way of potentially alienating minority groups from the process.

Regarding openness and transparency, it is interesting to note that only Ontario, Quebec, Manitoba, the Yukon, and the Northwest Territories have legislated the process in some detail in their governing statute. The British Columbia, Alberta, Saskatchewan, and Newfoundland statutes mention the advisory role of the Judicial Council in appointments, but federal, Nova Scotia, New Brunswick, and Prince Edward Island statutes only cite the power of the Governor in Council to make appointments. Lastly, only British Columbia, Ontario, Alberta, and the Yukon advisory committees publish an annual report of their activities. For those candidates interested in applying, statutes

Touchstones for Change, supra note 150 at 187.

Ontario Judicial Committee, supra note 149 at 2 . The percentage of applications from female lawyers also dropped considerably: ibid. at 20.

The exceptions are P.E.I. which has one female judge of three or 33 percent women; Alberta which has fourteen women of 103 judges or 14 percent; and Northwest Territories which only has male judges on the three-judge bench. 
and/or regulations would probably be the easiest, quickest, and most accessible source of information on appointments in their jurisdiction. In addition, although a statute may indeed be repealed or changed by the government of the day, changes to mere government policy have still fewer obstacles to overcome. After all, the public legislature and the inner sanctum of Cabinet are two very different forums of government decision-making.

\section{CRITERIA AND Qualifications}

Compared to a decade ago, the number of jurisdictions that have developed comprehensive criteria for appointment is a marked improvement in the process. However, only Alberta, Ontario, Nova Scotia, and the Yukon include "Demographics" and the need to have a representative bench as an actual criterion of assessment.

Although it is important to explicitly recognize the need for diversity on the bench, there are other criteria which may cause indirect or systemic disadvantage to underrepresented groups. For instance, at one time the statutory requirement of most provinces or territories was five years at the bar; now, this has been increased to ten years in the statutes of most jurisdictions. ${ }^{173}$ In Nova Scotia and British Columbia, where statutes still mandate five years as a minimum qualification, only in exceptional cases will the advisory committee consider an applicant with less than ten years of experience. Further, most judges usually have even more experience before being appointed; for example, in January 1998, sitting Provincial Court judges in Alberta had an average of 19 years of experience before being appointed, even though there is no legislated minimum. The rationale behind this policy is to ensure that the quality of appointments is on par with appointees at the federal level - that the provincial courts are not "inferior" courts and do not have "inferior" judges. However, minimum years of experience is, in a sense, an arbitrary qualification. It denies the breadth and types of experience a person may acquire despite having only five, seven, or ten years at the bar. Like "merit," 174 one's concept of "experience" can be contingent and fluid. The fact is, due to historical and present discrimination and to exclusionary barriers in the legal profession and society, many women and minority lawyers have not acquired the sort of experience which is assessed temporally. In this way, an emphasis on "professionalism" can result in the continuation of patterns of exclusion.

Similarly, a few jurisdictions also require medical records or "good health" for a candidate to be appointed. While seemingly reasonable, this could cause barriers for individuals with a disability that does not impede their ability to adjudicate. One criterion assessed by the Nova Scotia Judicial Appointments Advisory Committee is: "good health except to the extent that any physical or mental disability would not reasonably preclude performance as a Judge."175 Although this statement sufficiently insulates against human rights complaints, one might question the ability of an able-

The Northwest Territories requires a minimum of seven years at the bar: Territorial Court Act, R.S.N.W.T. 1988, c. T-2, s.7, as am. by S.N.W.T. 1998, c.14, ss. 4-5.

Infra, Part V.

Nova Scotia Guidelines, supra note 157. 
bodied advisor to understand the capabilities of persons with disabilities. ${ }^{176}$ From the information returned, there has only been one judge with a disability in Canada ${ }^{177}$ and, thus far, there appears to have been no discussion of accommodating disability among judges. ${ }^{178}$ Lastly, some jurisdictions with policy statements regarding representativeness in appointments, such as the federal process, focus on gender, ethnic, and cultural representation with no mention of disability. ${ }^{179}$

\section{THE COMMITTEE}

Like the process, the exact status, function, composition, and role of the judicial appointments advisory committees differ from jurisdiction to jurisdiction. Regarding status, only the federal committees and those in Nova Scotia, New Brunswick, and Prince Edward Island do not have a statutory existence, ${ }^{180}$ of those that do, only in Manitoba, Newfoundland, and the two Territories is the executive discretion legislatively restricted to the candidates recommended by the committees. ${ }^{181}$ As to functions, British Columbia, Saskatchewan, Newfoundland, and the Yukon use the provincial Judicial Council as the advisory body on appointments, and these councils are responsible for additional functions, rather than being strictly concerned with the appointments process. ${ }^{182}$ Further, the federal, Quebec, and New Brunswick processes divide the recruitment, vetting, and nomination functions between two or more bodies. No jurisdiction vests the appointment function in a body other than the executive.

Regarding composition, committees have anywhere from three to 13 members, but almost all include representatives of the bench, the bar, and the public (achieved through lay members). The federal committees, Ontario, Nova Scotia, Prince Edward

176 See e.g. D. Pothier, "Miles To Go: Some Personal Reflections on the Social Construction of Disability" (1992) 14 Dal. L.J. 526.

in In the past, there was one judge on the Nova Scotia Provincial Court bench in a wheelchair, however, he has since retired. It is uncertain whether his appointment was a result of the committee recommendation process.

Currently in Britain, the Lord Chancellor has begun a "pilot scheme" in an effort to remove visual impairment as a bar to appointment within the lay magistracy by providing documents in Braille or audiocassettes and by allocating cases according to the amount of visual evidence that is used: Lord Irvine of Lairg, "Speech to the Disability Law Conference" (Disability Law Conference, Inner Temple Mall, 13 February 1999) online: The Lord Chancellor's Department <http://www.open.gov.uk/lcd/speeches/1999/1999fr.htm> (date accessed: 17 May 1999).

However, to be fair, the Personal History Form does allow for self-identification as a person with a disability. This could lead one to infer that "cultural minorities" may encompass persons with a disability.

In Alberta, the Judicial Council is legislated in the Judicature Act, R.S.A. 1980, c. J-1, but the Provincial Court Nominating Committee has no statutory existence.

181 Although Ontario and Quebec also mandate appointment from the recommended candidates, there is a legislative provision allowing the Minister to request a new list or to renew the process. British Columbia's Provincial Court Act, supra note 136, provides that appointments will be made "on the recommendation of the council," but, in practice, the Minister is not confined to the Council's list.

sa Alberta added a nominating body in 1999 to enhance the role of its Judicial Council in assessing applications for judicial appointment and the Northwest Territories recently added a nominating body to take over the role of appointments from the Judicial Council. 
Island, the Yukon, and the Northwest Territories recognize the need for the committees to reflect the broad diversity of society, but only Ontario and both of the Territories have legislated this goal. Further, as mentioned above, only New Brunswick and the Yukon specifically provide for the participation of certain minority groups: francophone and First Nations peoples respectively.

Almost all the committees are dominated by members of the legal profession, be they judges or lawyers. The role of laypersons is clearly second order. ${ }^{183} \mathrm{We}$ would suggest that the reason for this can be traced to the underlying rationale for the creation of these committees: to modify the appearance of patronage by establishing a regime based on criteria of "objective merit." Merit is then best defined, understood, and assessed on the basis of professional standards, and the most appropriate decisionmakers are therefore one's professional peers, i.e., lawyers and judges.

We agree that this emphasis on professional standards is an improvement over the prior regime of crass political partisanship. However, there is a danger that an overemphasis on professionalism unduly prioritizes the values of legal technique (which we obviously value) at the expense of other potential judicial virtues. Such talents might be better assessed by non-lawyers. Judging, as we have argued in Part II, is more than mere legal technique; in consequence, an appointments system that overvalues technique may give preference to the self-reflecting values of established judges and lawyers.

The main difference between committees is the extent of their role in appointments. Broadly speaking, one can divide Committees into two types - screening or nominating. However, when looked at in combination with the distinct bodies that perform each function in the process, there are six slightly different committee models used in Canada. For clarification, the term "recruitment" will be used to refer to the body to which the applications are sent and then filtered; "screening" refers to the body which substantively reviews applications and assesses them; and "nominating" refers to the body which limits the choice of the government's candidates. ${ }^{184}$

(1) Recruitment by an independent body + Screening by the Committee + Executive Appointment (ss. 96 and 101 judges, excluding the Supreme Court)

(2) Recruitment by an individual designated by the Minister of Justice + Screening and Nominating by the Committee + Executive Appointment (Quebec)

(3) Recruitment and Screening by the Committee + Executive Appointment (Saskatchewan, Prince Edward Island)

(4) Recruitment, Screening, and Nominating by the Committee + Executive Appointment (British Columbia, Manitoba, Ontario, Nova Scotia, Newfoundland, the Northwest Territories, Yukon Territory)

Alberta is the exception in regards to its nominating committee with a majority of members being non-legal (six) and only two from the legal profession. However, the Judicial Council has a large complement from the bench.

That is, if there is a short list submitted, or if the statute mandates the government choose from recommended candidates only. 
(5) Recruitment and Screening by the Judicial Council + Screening and Nominating by the Committee + Executive Appointment (Alberta)

(6) Recruitment by the Department of Justice + Screening by Individual Advisors + Screening by an Interview Committee + Executive Appointment (New Brunswick)

The difference and extent of the advisory function played by the Committees is the most apparent difference. However, the apparent trend is towards an increased role by the Committees in nominating as opposed to their merely screening applicants; currently, committees in nine jurisdictions have the power to nominate individuals to the government. But it should be remembered that, of the nine, only the Yukon, Northwest Territories, and Manitoba combine the shortlisting of qualified candidates with a legislative restraint on the executive which requires it to select from the original list.

It appears that no model has had a significant empirical effect on the representation of historically marginalized groups on the bench. However, the more extensive systems are relatively recent in origin ${ }^{185}$ and the present statistics may not be the best gauge of "success." In the context of perceived political independence and transparency, some commentators prefer increased power for Committees in restraining government discretion, whereas those concerned with accountability favour a strict advisory role for the unelected members of the Committees. Which role would best promote the goals of representation and diversity? It could be surmised that the power of a Committee is relatively insignificant and only the resolve of the Minister matters when it comes to diversifying the bench; but if the government of the day is more concerned with promoting members of the "old boys club," then certainly no progress can be made. On the other hand, giving appointive power to a committee would be ineffective if the committee is indifferent to issues of representation during the recruitment and assessment of candidates. More accurately, it is probably a combination of all steps and actors in the process. Therefore, stronger policies and goals need to be articulated which would guide the recruiters, assessors, nominators, and appointers in the process. Indeed, we will later propose that what is required is a Judicial Appointments Commission.

Finally, it must be asked whether these new appointments processes are as significant an improvement over the traditional systems as is often suggested. All the systems propose or nominate several candidates to the relevant executive authority which, at that point, makes a decision based upon its unfettered discretion. Undoubtedly, this system guards against the egregious situations where positions are offered to candidates who are completely unsuited. Unfortunately, this can still leave room for a significant amount of patronage, especially if there are close connections between the political and legal elites of a particular jurisdiction, as there often is. Indeed, it is sometimes suggested that perhaps the executive likes the new system because it "takes the heat off" by creating an intermediate body that still allows the executive to make patronage appointments, but locates responsibility for the nomination elsewhere. It also provides 
the executive with a reply to some of its own supporters, whose aspirations for judicial glory have remained unfulfilled. ${ }^{186}$ Finally, the current systems do little to curtail the executives' capacity to rely on "secret soundings" in making a final decision.

In other words, it may be that political criteria remain an important, but submerged, dimension to the process. ${ }^{187}$ As we will suggest later, given the inescapably political nature of the judicial function and the importance of democratic principles, such political interventions are not necessarily a bad thing. However, politics needs to be conceived as something more than just traditional partisan politics and as including identity politics, and a more inclusive political structure (such as our suggested Judicial Appointments Commission) will need to be devised to accommodate the legitimate political dimensions of a judicial appointments process.

\section{RePReSENTATION POLICY AND OBJeCtives}

Currently, as mentioned above, most jurisdictions do have policy statements of some sort recognizing the need to diversify the bench and to have it reflect the community which it serves. The approach taken by the Alberta, Ontario, Nova Scotia, and Yukon processes appears more effective: "merit" is defined to include demographics and the need for diversity, which are not therefore mere additives to other "meritous" considerations. This approach integrates the goal of representation as part of legitimate assessment concerns, and avoids the risk of merely paying lip-service to the recognition of diversity. In a sense, adding a broad statement identifying the need for representation without supplementary measures for satisfying that need, as in the federal process, allows a jurisdiction to insulate itself from criticism, without actually changing the disadvantageous structures and barriers imposed on under-represented groups seeking appointment. The government can applaud its commitment to diversity if an individual from a minority group is appointed and shirk all responsibility if she or he is not chosen, because it has articulated a "commitment" to diversifying the bench. Again, the discourse of "professionalism" can become complicitous in perpetuating patterns of exclusion.

\section{TRANSPARENCY}

One of the rationales for the new appointments process is to engender greater legitimacy in the eyes of the general public. However, legitimacy requires transparency, and the new systems are still extremely inaccessible. Often, the statutory structure says little or nothing about the actual system in place. Frequently, what is in place is the consequence of policy directives or guidelines that are $a d$ hoc and informal. Indeed, to compose this Part of the article, one of the authors had to spend almost two months writing letters, e-mails, faxes, and making phone calls, etc. to a plethora of sources across the country. As will be suggested later, this lack of transparency might indicate that the commitment to greater inclusion may be more rhetorical than substantive. 


\section{E. SUMMARY}

In sum then, this empirical audit indicates that, statistically, the Canadian judiciary remains unrepresentative of the larger Canadian population and that, procedurally, the appointing processes lack informed participation by the individuals and groups affected. This democratic deficit remains fairly consistent across the country, although few jurisdictions share the same processes for judicial appointments. All processes share certain deficiencies in transparency, representation policy, representativeness of the nominating committees, and clear selection criteria. The difference now is that perhaps we are witnessing a hierarchy of historically marginalized groups. Some groups (women) are being less marginalized than others. However, the identification of a statistical mismatch is not an argument; it is merely a description. Consequently, in the next section arguments for and against the pursuit of a more proportionately representative judiciary are assessed.

\section{BEING There AND SPEAKING UP: NORMATIVE ARgUMENTS FOR AND AGAINST A PROPORTIONATELY REPRESENTATIVE JUDICIARY}

In Part II, we argued that the judiciary is one of the most potent political forces in the current Canadian polity. We further suggested that an emergent judgocracy must be a serious worry to anyone committed to democracy. In particular, we expressed concerns about mechanisms of accountability and responsibility. Part III indicated serious reservations in this regard. In terms of both the appointment process and the raw numbers, we appear to have a relatively closed and cloistered judicial fraternity that barely reflects the complex nature of Canadian society.

In recent years there have been frequent calls for a more diversified judiciary. For example, article 2.13 of the Montreal Universal Declaration on the Independence of Justice 1982 proclaims "the process and standards of judicial selection shall give due consideration to ensuring a fair reflection by the judiciary of the society in all its aspects." 188 In Ontario, alongside the criteria of professional excellence, community awareness, and personal characteristics, there is explicit statutory "recognition of the desirability of reflecting the diversity of Ontario society." 189 Similarly in the Yukon, the Territorial Court Act provides that the bench should be "demographically representative of the community it serves." ${ }^{190}$ Often, such propositions are justified on the basis that the judiciary should reflect the broad diversity of the mosaic that we call Canada. It is assumed that "reflection" is an unqualified and indisputable human good. Rarely, however, have advocates of judicial diversity provided a cogent justification of why diversity is a good thing. ${ }^{191}$

189

Cited in D. O'Sullivan, "Gender and Judicial Appointment" (1997) 19 U. Queensland L.J. 107 at 109.

Courts of Justice Act, supra note 146, s. 43(9), as am. by S.O. 1994, c. 12, s. 16.

S.Y.T. c. 26 , s. 9 (c)(i).

But see Smith \& Grant, supra note 55; Mendes, supra note 55. These studies are helpful in that they canvass some of the arguments in favour of increased diversity; they do not, however, adequately delineate or engage with potential counter arguments. What follows is, we hope, a more comprehensive engagement and assessment. 
In this section, we articulate and explore the arguments both for and against judicial diversification. To do so we draw on some recent literature in political theory. In the last decade, there has been an important debate in political science as to whether electoral policies should be developed to ensure that historically under-represented groups are proportionately represented in legislatures. In particular, this has focused on the United States and the striking under-representation of women and African Americans. We believe that this debate can help us think about the demand for a proportionally representative judiciary in Canada. ${ }^{192}$ While there are obviously important functional and institutional differences between judges and politicians, we wish to re-iterate the point we made in Part II, that the differences between the judiciary and legislatures as institutions of democracy are differences of degree, not of kind. Indeed, we would go even further to suggest that because politicians are so preoccupied with party platforms and so constrained by party discipline, they do not actually exercise much political power as individuals. In contrast, we would suggest that due to the wide, extremely intrusive and highly discretionary powers possessed by judges, they, as individuals, wield enormous political power over people's lives. Hence, the importance of discussing proportional representation in the judiciary can no longer be ignored on the basis of apolitical assumptions. In light of these concerns, the focus of this section is an inquiry into the relationship between "group identity, political equality, and fair representation." 193

\section{A. ARguments for a mORe Proportionately Representative Judiciary}

We have identified eight arguments that suggest a link between democracy and greater representation of historically marginalized groups in the judiciary. All of these arguments, however, must be considered in light of the arguments opposing measures which encourage proportional representation, discussed in the next section.

\section{INDIVIDUAL RIGHTS/ EQUALITY ARGUMENT}

This is basically a conventional liberal, non-discrimination, equal opportunity analysis: ${ }^{194}$ because there is no rational reason to assume that members of marginalized groups are not as talented as are members of dominant groups, there is something seriously askew when certain social groups dominate judicial appointments, while others are significantly under-represented. This suggests that there must be something in the system which, either by design or unintentionally, has the effect of excluding historically marginalized persons. As Melissa Williams has commented, "it is difficult to ignore the suspicion that the 'under-representation' of historically

We wish to thank Dr. Alexandra Dobrowolsky for bringing much of this literature to our attention. In particular we will draw upon Anne Phillips, supra note 29 and Melissa Williams, supra note 2.

193 Williams, ibid. at $117,118$.

194 J. Rawls, A Theory of Justice (Cambridge, Mass.: Belknap Press of Harvard University Press, 1971) at 221-227; J. Raz, "Multiculturalism: A Liberal Perspective" (1994) 41 Dissent 67 at 69; R.M. Unger \& C. West, The Future of American Progressivism: an Initiative for Political and Economic Reform (Boston: Beacon Press, 1998) at 74; Williams, ibid. at 119-24. 
marginalized groups is related to the history of discrimination against them." 195 The concern is that of systemic discrimination and distributive injustice; positions of power, privilege and respect are being inequitably allocated, thereby perpetuating inequality. ${ }^{196}$ Our discussion in Part III indicates that merit is not the sole, exclusive, and determinative criterion for appointment. ${ }^{197}$ A proportionally representative judiciary may help challenge such practices and, therefore, recognize the individual abilities of members of historically excluded groups.

The other strain of this argument proposes that equality before and under the law must mean equal opportunity to make and enforce the law, ${ }^{198}$ and not merely equal application of the law. The statistics are stark, particularly with regard to Aboriginal peoples and African-Canadians: massive over-representation as accused in the legal system, but significant under-representation as judges in that same system. ${ }^{199}$ The goal, then, is power sharing, "a right to share in the exercise of [legal] authority." As Anne Phillips has noted: "political equality involves some degree of equality in participation."201

We find both aspects of this argument persuasive. However, they need to be considered in the light of the counterarguments and, in particular, the "pool problem." As will be discussed later, ${ }^{202}$ one consequence of the historical and systemic discrimination of under-represented groups has been small numbers in the "qualified pool" of judicial candidates. Thus, although there may be some candidates of equal talent and "merit," there may also be a practical barrier to increased appointments of historically marginalized individuals.

\section{EFFICIENCY ARGUMENT}

This is a by-product of the first argument and is premised on the insights of liberal economic commentators. It is essentially a functionalist argument. Historically marginalized groups are a significant social resource, and their ongoing exclusion is a waste of social talent. Canadian society would benefit from the maximization of the

Williams, ibid. at 3. There may some empirical evidence to support this. In European career systems where appointments are based on a more "objective" examination system, "women normally fare better than men": U.K., Lord Chancellor's Department, Research Series no. 6/97, "Judicial Appointments in Continental Europe" by C. Thomas (London: Her Majesty's Stationery Office, 1997) at 21-22.

W. Kymlicka, "Group Representation in Canadian Politics" in F.L. Seidle, ed., Equity and Community: the Charter, Interest Advocacy, and Representation (Montreal: IRPP, 1993) 61 at 70. See also P.A. Russell \& J.S. Zeigel, "Federal Judicial Appointments: An Appraisal of the First Mulroney Government's Appointments and the New Judicial Advisory Committees" (1991) 41 U.T.L.J. 4.

Williams, supra note 2 at 157.

See e.g. Ontario, Final Report of the Commission on Systemic Racism in the Ontario Criminal Justice System (Toronto: Queens Printer, 1995) (Co-chairs: M. Gittens \& D. Cole) [hereinafter Ontario Report on Systemic Racism] and Part III of this article. 
talent and abilities of all its individuals. The quality of the judicial system would be improved by opening up the system to an influx of untapped and underutilized potential. ${ }^{203}$

This seems to us to be an uncontroversial, if somewhat crude, argument. The only qualification we would add is that this argument is premised upon faith in the process of appointments being based purely on adequately defined meritorious considerations. Unfortunately, this has often not been the case in Canada. Political patronage, while perhaps on the decline, was often a major consideration in past appointments. ${ }^{204}$ As well, the lack of transparency and accountability in the present process makes any guarantees of merit-based appointments still somewhat questionable.

\section{DEMOCRATIC ARGUMENT}

There are two dimensions to this argument. One aspect is a citizenship argument: democratic principles mandate that "those who are bound by a system should be participants in it." 205 A democratic institution must be open to the input of those upon whom it has an effect; ${ }^{206}$ there must be "[an] equal capacity for selfdetermination." 207 To the extent that the judiciary both makes and enforces the law, it must be open to the participation and views of a larger citizenry, rather than a privileged fraternity.

The other aspect is a prudential argument. Democrats are deeply aware of the "fundamental fallibility of human reason" and are sceptical about the "pretensions of political élites." ${ }^{208}$ Consequently, any institution that exercises power needs to be pried open to as broad a variety of perspectives as possible in order to avoid the dangers of solipsism and the entrenchment of anachronistic and unresponsive values. Sherrilyn Ifill calls this "structural impartiality." 209

Again, we find much that is helpful in these arguments. If we must have a judgocracy, then at least this judgocracy should broadly reflect the different communities that constitute our society. There can be no assumption that any one group has a monopoly on the good.

D.J. Amy, Real Choices/New Voices: The Case for Proportional Representation Elections in the United States (New York: Columbia University Press, 1993) at 100; Williams, supra note 2 at 12831; M. Juccoud \& M. Felices, "Ethnicization of the Police in Canada" (1999) 14 C.J.L. Soc. 83. See generally Judicial Selection in Canada, Discussion Paper and Reports (Toronto: Canadian Association of Law Teachers Special Committee on the Appointment of Judges, 1987) [hereinafter Judicial Selection in Canada].

Grant \& Smith, supra note 55 at 64 . This is analogous to the "no taxation without representation" argument. Phillips, supra note 29 at 29.

Ibid. at 28.

S.A. Ifill, "Judging the Judges: Racial Diversity, Impartiality and Representation on State Trial Courts" (1997) 39 Boston Coll. L. Rev. 95 at 99. 


\section{VOICE/AUTHENTICITY ARGUMENT}

The first three arguments appear to be based upon a presumption that those who have been historically excluded might have something distinctive to contribute to the judicial process. This is made explicit by the voice argument. This is an epistemological claim in that it proposes that the experience of marginalization generates a distinctive and authentic perspective on matters of law that requires the self-representation of the historically excluded so as to give voice to that perspective. ${ }^{210}$ This is sometimes called "looking to the bottom," "211 "outsider jurisprudence"212 or a "different voice." ${ }^{\text {"213 }}$ The two key ideas here are: a) our various positions in the social hierarchy have a profound impact on our understanding of reality; and b) our experiences of different social contexts circumscribe our cognitive ability to understand.

In the context of the judicial role, it is suggested that because most judges come from the dominant community, they make law in their own image, an image that fails to factor in the contexts of those who have been excluded. ${ }^{214} \mathrm{~A}$ more proportionately representative judiciary would introduce a broader variety of authentic experiences and perspectives and, thereby, would contribute to a more contextualized and socially sensitive decision-making process. ${ }^{215}$ It would also generate a more realistic sense of which alternatives are more likely to succeed in the struggle against inequality. ${ }^{216}$

We have a lot of sympathy for this argument, so long as it is carefully articulated. There is no doubt in our mind that experience informs and circumscribes our perspectives and, therefore, is an important variable. ${ }^{217}$ For example, as a result of their recent interviews with Canada's appellate court judges, Greene et al. argue that discretion is pervasive, of "fundamental importance," even "astounding."218 They conclude: "[w]hat determines a particular judge's decision is the interplay of his or her personality, background, values, and legal education." 219

Kymlicka, supra note 196 at 67; Williams supra note 2 at 6, 20, 119, 131-37, 163.

211 M.J. Matsuda, "Looking to the Bottom: Critical Legal Studies and Reparations" (1987) Harv. C.R.C.L. L. Rev. 323.

212 M.J. Matsuda, "Public Response to Racist Speech: Considering the Victim's Story" (1989) 87 Mich. L. Rev. 2320 at 2323. (Cambridge, Mass: Harvard University Press, 1982).

"Women Judges," supra note 59 at 515-516; Young, supra note 206 at 137.

Williams, supra note 2 at 241.

217 See also J.E.B. v. Alabama, 511 U.S. 127 (Ct. Civ. Appeals, 1994) at 148-49 (O'Connor J.); Grant \& Smith, supra note 55 at 66-67; J. Webber, "The Adjudication of Contested Social Values: Implications of Attitudinal Bias for the Appointment of Judges" in Appointing Judges: Philosophy. Politics and Practice (Toronto: Ont. Law Reform Commission, 1991) 3 at 14. 
However, we want to resist the suggestion that identity automatically engenders authenticity, and that "shared experience guarantees shared beliefs." ${ }^{220}$ Experience and identity are fluid, interpretable and complex, and never unidimensional. ${ }^{221}$ Consequently, we suggest that so long as identity is not presumed to be proxy for truth or authenticity, then the real issue is proportional access to the channels of judicial decision-making so as to open up what has been an excessively constrained set of perspectives.

In this regard, we find Jill Vickers distinction between "speaking out" and "speaking for" to be very helpful. ${ }^{222}$ For example, while it is difficult to prove any causal connection between identity and perspective, ${ }^{223}$ we would suggest that the debates

Phillips, supra note 29 at 53 [emphasis in original]. See also T. Morrison, "Introduction: Friday on the Potemac" in T. Morrison, ed., Race-ing Justice, En-Gendering Power: Essays on Anita Hill, Clarence Thomas, and the Construction of Social Reality (New York: Pantheon Books, 1992) vii; O'Sullivan, supra note 188 at 111 .

$\mathrm{K}$. Abrams makes the same point as follows:

[T] he social affinities or influences that shape the discretion of the realist judge are more numerous, less explicit, and more potentially contradictory in their mandates, and, consequently, less predictable in their effect. Many of these influences, particularly groupbased identities or affiliations, may shape judges' consciousness or frame their responses in ways that are neither predictable ex ante nor uniform when observed ex post. For example, both Justice Ginsburg and Justice O'Connor describe themselves as having had experiences related to their female gender that have shaped their approach to their profession, or to institutions of education or employment. Yet these experiences or affiliations have produced perspectives that are distinct on the gender issues that have come before the Court, in part because these gender experiences are themselves complex and distinct, and contend with other constitutive experiences and commitments for influencing the Justices' decisionmaking. Not only are these influences plural and contingent, they also are not necessarily focused on or framed to respond to legal issues.

Abrams continues in footnote 57:

Neither Justice has simply had the experience of "a woman" in the legal profession: Both have had the experience of elite white women, at the highest levels of academic opportunity and achievement. Justice Ginsburg's perceptions of gender may be mediated through her experience as a feminist law reformer or as a law reformer who espoused a particular liberal feminist position on gender inequality. Justice O'Connor's perceptions of gender may be framed by her early experience as a full-time mother or her later experience as a leader in a largely male, state legislative arena. In either case, the Justices' perceptions regarding gender are not the only or even the controlling influence on their decisionmaking. They vie in some incalculable atmospheric conflict with other assumptions about difference, judicial role, statutory interpretation, and more.

K. Abrams, "Some Realism about Electoralism: Rethinking Judicial Campaign Finance" (1999) 72 So. Cal. L. Rev. 505 at 520-21. See also J. Vickers, "Toward a Feminist Understanding of Representation" in J. Arscott \& L. Trimble, eds., In the Presence of Women: Representation in Canadian Governments (Toronto: Harcourt Brace \& Co., 1997) 20 at 42.

Vickers, ibid. at 28, 44.

See the rather pointed, and methodologically contentious, debate between P. McCormick \& T. Job, "Do Women Judges Make a Difference? An Analysis by Appeal Court Data" (1993) 8:1 C.J.L. Soc. 135; J. Brockman, "A Difference Without a Distinction?" (1993) 8:1 C.J.L. Soc. 149; P. McCormick \& T. Job, "Hypotheses, Statistics, and Women Judges: A Response" (1993) 8:1 C.J.L. Soc. 165. See also O'Sullivan for a discussion of some American and British studies in this regard, supra note 188 at $118-121$. 
generated by $R$ v. Lavalle $e^{224}$ on the "battered woman syndrome" and $R$ v. $O^{\prime} C^{\prime}$ nnor ${ }^{225}$ and $R$. v. Mills ${ }^{226}$ on access to the therapeutic records of sexual assault survivors are in large part a consequence of the presence of women on the Supreme Court. ${ }^{227}$ By speaking out, the perspectives of women have been given much greater voice and consideration, than they were previously. However, it could not be said that Justices Wilson, McLachlin, or L'Heureux-Dubé were attempting to speak for all women. For example, as the $R$. v. Seaboyer ${ }^{228}$ case on the rape shield laws indicate, Justices McLachlin and L'Heureux-Dubé can espouse quite contradictory views.

In addition, there is evidence to indicate that the current legal system does value nonidentity, and even some identity-based, perspectives. Greene et al. report that in

most ... provinces ... the chief justice makes modifications to a perfectly random combination of [appellate] panels to take into account factors such as a mix of well-seasoned and less experienced judges, gender balance, regional location, the perceived need to have a judge on a panel who is an expert in the areas of law related to the cases on the panel's docket, and, in some provinces, whether the judges get along with each other. In Ontario the chief justice ensures that each panel that is assigned a criminal case has at least one judge experienced in criminal law, and the same principle is followed for civil cases. ${ }^{29}$

Even more poignant is Justice Wilson's claim that when she was "on the Ontario Court of Appeal, [there was] a quite prevalent view that appointments to the Court should alternate between judges elevated from the trial division and candidates appointed directly from the profession or the academic community." ${ }^{230}$

Diversity of experience is therefore already assumed to be a judicial good, so why not simply expand the parameters to be even more inclusive?

\section{DELIBERATIVE ARGUMENT}

The fourth (voice) argument, like those which preceded it, relied upon a presumption about the judicial decision-making process. This fifth argument makes this presumption

[1990] I S.C.R. 851, per Wilson J.

[1995] 4 S.C.R. 411, per L'Heureux-Dube J. The decision of L'Heureux-Dube J. became the basis of Criminal Code reforms on the disclosure of therapeutic records.

[1999] 3 S.C.R. 668.

In a different context, Amy has noted that "[ $[$ ] he notion that increased minority representation can further minority interests is supported by a number of studies that show that increased black representation in city governments has made these institutions 'more attentive and responsive to their needs for basic community services,"' D. Amy, supra note 203 at 115. Similarly, Vickers argues that there is some evidence to support the claims that "women legislators are more likely to be 'liberal', more likely to be feminist, have been successful, and more likely to raise women's concerns in the legislature than men" and "women legislators in forcing their colleagues to comprehend political issues from women's perspectives": J. Vickers, supra note 221 at $34,31$.

(1991), 83 D.L.R. (4th) 193.

Greene et al., supra note 67 at 65 [footnotes omitted].

B. Wilson, "Methods of Appointment and Pluralism" in D. Magnusson, D. Soberman, eds. Canadian Constitutional Dilemas Revisited (Kingston: Centre for Public Policy, 1997) 154 at 161. 
explicit. The presumption is that legal decision-making is a rational and deliberative process, that is, after lawyers on either side present their arguments, judges then retire to ponder and discuss the arguments with their colleagues. A pivotal assumption is that judges actually approach a problem with a relatively open mind, and are willing to be persuaded by the process of discursive engagement. ${ }^{231}$ The deliberative ideal posits that a proportionally representative judiciary would provide an opportunity for the development of channels of communication, openness, mediation, and mutual understanding. ${ }^{232}$ The hope is that the participation of judges from historically excluded communities can open up the judicial conversation, to introduce hitherto unfamiliar and unexplored contexts so as to facilitate an "enlargement of mind" ${ }^{233}$ for all judges.

Again, we have some sympathy for this argument. Empirically, there is evidence to support the premise that judges deliberate as a group at both the Supreme Court and the appellate levels. ${ }^{234}$ Indeed, we would suggest that the central justification for appellate courts sitting in panels is not just the majoritarian principle, but also the idea that "several heads are better than one." The assumption is less obviously true for busy trial judges who sit alone and rarely reserve judgement. However, there is no doubt that even trial judges who sit alone frequently discuss their cases with colleagues, at least informally. More formally, there are judicial education programmes where judges have the opportunity to engage in collective discussion and reflection.

But again we want to sound a note of caution. We have no doubt that most judges operate in the good faith belief that they are impartial, open-minded, and committed to doing the "right" thing. However, we should not inflate the significance of this subjectivist perspective because, as we outlined in our discussion of neo-realism, there are other forces at play that channel and constrain the judicial imagination. Thus, while we think that a deliberative argument has some merit - it can help open up the judiciary - we should not fall into a false idealism. As we have indicated earlier, there are other variables that have an impact on the judicial mentality, such as underlying jurisprudential predilections, ideology, interests, and material position. But while ideas are not everything, they are not nothing either. Consequently, the more space that previously excluded groups can attain, the broader the judicial conversation might become.

Mendes, supra note 55 at 103-106; Webber, supra note 217 at 27.

Phillips, supra note 29 at 151-53; C.R. Sunstein, "Preferences and Politics" (1991) 20 Philosophy and Public Affairs 3 at 17, 33-34; Young, supra note 206 at 126-31, 135-36; Williams, supra note 2 at $137-48$.

J. Nedelsky, "Embodied Diversity and The Challenges to Law" (1997) 42 McGill L.J. 91 at 107. See also Ifill, supra note 209 at $139,149$.

Greene et al., supra note 63 at 63, 70, 76-79, 110, 118-25, 207-10; "Decision Making," supra note 34 at 236-38. 


\section{TRUST/CONFIDENCE/LEgITIMACY ARGUMENT}

This is basically a prudential argument. Modern Canadian society is comprised of many diverse communities. The smooth operation of our society requires a widespread commitment to, and participation in, the institutions of government.

Of particular importance are faith in, and respect for, the legal system. As Rawls has argued, "[a] just system must generate its own support." ${ }^{235}$ How can one expect the diverse communities to trust in the legal system if judges do not represent the diversity of contemporary society? ? $^{236}$ The legitimacy of the judicial system is contingent upon public confidence. Recent reports have indicated that marginalized communities in Canada have significant concerns about the judiciary. ${ }^{237}$ One way to achieve such trust and reduce alienation is to make the judiciary more reflective of the communities that make up the society. ${ }^{238}$

Some commentators have even suggested that if one merges the trust and deliberation arguments, one might even generate a "spiral of trust": the greater the number of persons from marginalized groups, the greater the possibility for their discursive input which, in turn, will improve communication and understanding and, thereby, generate more responsive decisions which will increase confidence in the system, consequently encouraging greater participation. ${ }^{239}$

We are not as persuaded by these arguments as are others. Our neo-realist theory of law is premised on a deeper social and political theory that sees society closer to the conflictual end of the spectrum than consensualist models permit. The prudential argument comes a bit too close to what some describe as the "add minorities and stir" approach to diversity that fails to account for the challenges of pluralism. It also involves a complex assessment of political psychology that we are unqualified to adequately consider. However, it seems to suggest that, for example, an accused will be less aggrieved by being convicted by a person who shares his or identity than one who does not. Again this assumes that one aspect of a person's identity trumps other aspects, but identities are not all encompassing and unidimensional; they are fluid and complex. Indeed, it might even be suggested that a conviction by a person who shares a similar identity could intensify an accused's sense of alienation because the judge is perceived to have sold out or have been assimilated. As for the spiral of trust argument, it appears conjectural.

But we do not reject these arguments outright. For example, it might be suggested that one reason why the decision in the Quebec Secession Reference ${ }^{240}$ case seemed

Rawls, supra note 194 at 261.

Amy, supra note 203 at 102; S. Cooney, "Gender and Judicial Selection: Should There be More Women on the Courts?" (1993) 19 Melboume U.L. Rev. 20 at 21; Grant \& Smith, supra note 55 at 64-65; Kymlicka, supra note 196 at 67; Williams, supra note 2 at 136-37, 170.

Ontario Report on Systemic Racism, supra note 199 at c. 2.

Amy, supra note 203 at 116; "Women Judges," supra note 59 at 518.

Williams, supra note 2 at 172 .

Supra note 83 .
} 
to generate so little controversy in Quebec is because three Quebecois judges were part of the unanimous decision.

\section{SYMBOLIC/EDUCATIVE ARGUMENT}

Judges epitomize success and respect in Canadian society. It is important for the selfperception and self worth of a group that it be socially respected through participation in the institutions of state. ${ }^{241}$ Role modelling is one specific aspect of this symbolic function. It is important, particularly for younger generations, for there to be a representative judiciary, because it can generate a sense of achievable goals. ${ }^{242}$

Equally important is the idea that a representative judiciary can help foster group recognition because there is public acknowledgement of a group's positive contribution to society. ${ }^{243}$ Negative stereotypes about various communities abound in Canadian society, thereby devaluing them. The appointment of judges from historically excluded communities challenges such stereotypes, educates the larger public that diversity is a strength to be valued and respected and not a liability or a cause for disparagement, and it fosters attitudinal change. ${ }^{244}$ Consequently, it is desirable that the judiciary should be a portrait or microcosm of the larger society in order to "reflect the twin principles of equality and diversity." 245

We agree that symbolism is a powerful dimension of law. Whether it be justice blindfolded, the scales of justice, the garb of judges, or the architecture of courthouses and courtrooms, the legal community is deeply committed to the symbolic. In our opinion, the symbolic significance of a diversified judiciary is just as important, for there is a powerful bite underlying the old aphorism that justice must not only be done, but be seen to be done. ${ }^{246}$

Indeed, we would argue that, historically, Canada has recognized the symbolism of judicial appointments. Although it is sometimes suggested that the reason for having a significant number of judges trained in the civil law system on both the Supreme Court and the Federal Court is due to the importance of the different methodologies of

Ifill, supra note 209 at 137-38; Vickers, supra note 221 at 27; Williams, supra note 2 at 174.

J. November, "A Woman's Place is on the Bench" (1993) 23:6 Victoria University of Wellington L. Rev. 85 at 101-103.

See generally C. Taylor, "The Politics of Recognition" in A. Gutmann, ed., Multiculturalism and the Politics of Recognition (Princeton: Princeton University Press, 1992); L. Guinier, The Tyranny of the Majority: Fundamental Fairness in Representative Democracy (New York: Free Press, 1994); Williams, supra note 2 at 134.

Amy, supra note 203 at 116; Grant \& Smith, supra note 55 at 65.

B. Wilson, "Methods of Appointment and Pluralism" in D.N. Magnusson, D.A. Soberman, eds., Canadian Constitutional Dilemmas Revisited (Kingston: Institute of Intergovernmental Relations, 1997) 159 at 160 [hereinafter "Methods of Appointment"].

A word of caution. Like Ifill, supra note 209 at 138, we worry that sometimes the symbolic is confused with the actual. The cumulative goal of all the arguments presented here is real participation, and the symbolic argument is but one aspect of this project. For further discussion of the danger of symbolism, see R.F. Devlin, "We Can't Go On Together With Suspicious Minds: Judicial Bias and Racialized Perspective in R. v. R.D.S." (1995) 18 Dal. L.J. 408. 
the traditions, recent research indicates that most Supreme Court and Federal Court of Appeal justices themselves do not believe that their legal training has much impact on their decision-making. ${ }^{247}$ The real, and appropriate, reason for the appointment of these judges is Canada's commitment to being inclusive of the French culture. But if this is the case, why is this particular fact symbolically acknowledged while other facts are ignored?

\section{MORAL VIRTUE ARGUMENT}

There is a strong and a weak version of this argument. In the strong version, advocates are inclined to suggest that some groups, especially women, are more morally sensitive than others, and that this would have an impact on substantive decisionmaking. ${ }^{248}$ Few make these arguments explicitly today, but sometimes this is implicit in certain versions of the voice argument discussed previously. It is an argument that we reject completely for, as Anne Phillips points out, "no one group has a monopoly on virtue."249

The weak version of the argument suggests that group representation is important because it assists those who traditionally have had power to reconsider, through constructive engagement with the historically marginalized, many of their own insufficiently considered, taken-for-granted assumptions. ${ }^{250}$ It engenders an awareness of the contingency and fallibility of conventional wisdom. Consequently, it is suggested that judicial judgements will be more sophisticated and more robust. We are somewhat more sympathetic to this argument, so long as one does not become over-enthusiastic about the possibilities of understanding across diversity - the problems of which we will discuss below in Part IV.B.3.

\section{B. ARguments Against Group Representation}

We have identified eleven arguments that may be invoked against either the idea of a proportionally representative judiciary, or potential mechanisms that might be pursued in support of the idea. Further, as we have done with the arguments above in support of greater diversification, we will attempt to tease out the positive and negative aspects of each.

\section{INDIVIDUAL MERIT/ LIBERTY ARGUMENT}

This argument is opposed to proactive measures for diversification because of the following rationale: an appointments process that prioritizes a person because of her or his group identity will mean that other more talented candidates will be penalized. The

\footnotetext{
247 Greene et al., supra note 67 at 104.

248 For discussion, see Williams, supra note 2 at 124-28. See also D. Bright, "The Other Woman: Lizzie Cyr and the Origins of the 'Persons Case'" (1998) 13:2 C.J.L. Soc. 99.

$249 \quad$ Phillips supra note 29 at 17 . See also Mendes, supra note 55 at 98.

$250 \quad$ Young, supra note 206 at 137.
} 
argument for "difference blindness" 251 is premised on the familiar claims of reverse discrimination and the abandonment of the meritocratic principle. ${ }^{252}$ We have several counterarguments in this regard.

First, the assumption underlying such a position is that we should have, and currently function under, a free market in judicial appointments. This is simply not accurate. Regional representation and political affiliation, for example, remain important variables. ${ }^{253}$ The historical reality is that Canada has never been committed to a system of pure merit for judicial appointments. At the federal level, and particularly at the Supreme Court level, territorial and linguistic identities have always been considered legitimate concerns. ${ }^{254}$ At times, religion has also been a factor ${ }^{255}$ and diversity of legal experience appears to be yet another. ${ }^{256}$ A Scottish, English, Irish, or French ancestry has also been helpful. ${ }^{257}$ At the provincial level, some provinces have sought to reflect the cultural heritage of the province, for example, by preferring bilingual judges. ${ }^{258}$ But why is territorial or linguistic identity presumed to be a more legitimate criterion for appointment than one's race or gender? ${ }^{259}$ As Melissa Williams reminds us, " $(t)$ erritorial representation has its origins in feudal parliaments." ${ }^{260}$ But while territorial identity is an important political consideration, there is no reason to assume that it is the only political consideration. Indeed an argument can be made that, in contemporary Canada, other political identities are perhaps even more important than territory, especially gender, disability, race, and class.

Second, Canada's constitutional values are not exclusively or absolutely individualist, but also communitarian. Thus, we have entrenched minority language rights, equality

Williams, supra note 2 at 5 .

Amy, supra note 203 at 130; Cooney, supra note 236 at 43; Grant \& Smith, supra note 55 at 79 81; O'Sullivan, supra note 188 at 123-24.

Bushnell, supra note 118 at 19-22; Greene et al., supra note 67 at 36, 155, 196.

K.G. Banting, "Federalism and the Supreme Court of Canada: The Competing Bases of Legitimation" in Ontario Law Reform Commission, supra note 217, 31 at 46; Bushnell, supra note 118 at 15-18.

Bushnell, ibid. at 11-14; B. Laskin, "The Supreme Court of Canada: A Final Court of and for Canadians" (1951) 29 Can. Bar Rev. 1038 at 1041; L.E. Weinrib, "Appointing Judges to the Supreme Court of Canada in the Charter Era: A Study in Institutional Function and Design" in Ontario Law Reform Commission, supra note 217, 109 at 117. It is interesting to note that the biographies of the Supreme Court of Canada justices included in The Supreme Court of Canada and Its Justices 1875-2000: A Commemorative Book (Ottawa: Supreme Court of Canada, 2000) make no reference to the religion or ethnic background of the justices.

"Methods of Appointments," supra note 230 at 161 . "The pattern of appointments over the last quarter of a century [to the Supreme Court of Canada] suggests that this ratio of seven from the provincial appeal courts, one from the Federal Court, and one without prior judicial experience can be taken as intentional and persistent": Greene et al., supra note 67 at 101, 149.

Bushnell, supra note 118 at 22. See also U.K., Justice Society, The Judiciary in England and Wales: A Report (London: Justice, 1992) [hereinafter Justice Report].

C. Kendall, "Criticism and Reform: A Survey of Canadian Literature on the Appointment of Judges" in Ontario Law Reform Commission, supra note 217, 211 at 221. This is explicit in New Brunswick. See infra, Part III, C.2.b.(vii).

Webber, supra note 217 at 27.

Williams, supra note 2 at 71. 
rights, multicultural rights, gender equality rights, and Aboriginal rights; all of which acknowledge the importance of group identity and identification. ${ }^{261}$

Third, the problem with the individual merit perspective is that it ignores the complex and deeply entrenched structures of social exclusion that make access to legal education, legal practice, and therefore the judiciary, extremely difficult. Patronage is only the tip of the iceberg in this regard. ${ }^{262}$ In other words, although the current judicial appointments process is formally and facially neutral, it appears to reproduce itself solipsistically. Consequently, as Sheldon Goldman has argued in the American context, "[i]ronically, affirmative action may provide a more potent push towards merit selection than anything else that has ever been done." ${ }^{263}$ The position we advance then, is not based on a theory of compensation for past wrongs, but on current inequality.

Fourth, merit is often a taken-for-granted assumption, the parameters of which remain unspecified. But surely it is appropriate to ask, what does merit concretely mean in the judicial appointments context? What are the determinative criteria? ${ }^{264}$ Judicial reflections on merit do not seem to go much beyond the nebulous virtues of "patience, ... openness to the arguments of counsel.... good knowledge of the law, the ability to write well, promptness, ... quality of [] ... reasoning.... intelligence.... industriousness, honesty, humility, being collegial and helpful, and being compassionate and polite."265 Similarly, the various criteria for appointment, as specified in statutes and policy guidelines (see Appendix II), while somewhat helpful, are also quite indeterminate. Moreover, we would suggest there are no reliable predictors; there is no necessary correspondence between the skills connected with successful legal practice and those required for desirable judicial performance. ${ }^{266}$

Much can be learned from recent human rights jurisprudence in this regard. Often the qualifications of a job are set in a way that reflects a majority white male norm, rather than the actual minimum requirements for the job. This is true in respect to judging as well as other jobs and professions. Thus, many employment qualifications are not the objective standards that are claimed, nor are they really necessary to do the job effectively. Such a realization not only weakens the critique about watering down "objective" standards, it also suggests that the pool of non-traditional, qualified candidates may be considerably larger than is generally assumed.

In a rather sophisticated equality analysis, the Supreme Court of Canada reinforced these points in the 1999 decision of British Columbia (Public Service Employee

Charter, supra note 11.

Judiciary in Canada, supra note 15 at 112-21; Greene et al., supra note 67 at 37.

S. Goldman, "Should there be Affirmative Action for the Judiciary?" (1979) 62 Judicature 489 at 491 .

"Methods of Appointments," supra note 230 at 162.

Greene et al., supra note 67 at 27-28, 102. See also Appendix II; many jurisdictions include similar qualities under the heading of "Personal Characteristics" as criteria for appointment.

B. Schwartz, "On Choosing Judges - Oracles and Performers; or Philosophers and Sages?" (1992) 17 Queen's L.J. 479 at 487.
} 
Relations Committee) v. BCGSEU ${ }^{267}$ This case involved the use of a standard aerobic fitness test for firefighters, which the Court found had an adverse impact on women and was not demonstrably justifiable for the job of firefighting. ${ }^{268}$

While there are no exact equivalents to aerobic fitness tests for judges, nor are there standardized psychological tests for judges, the principles enunciated in the $B C G S E U$ case are relevant to the arguments being explored. The flavour of that decision is revealed in the following quotations from the case, which started as a decision by a human rights tribunal based upon a complaint of sex discrimination. Justice McLachlin (as she then was), speaking for the Court, makes the following statements about the need for systemic solutions to remedy systemic discrimination and the hidden prejudices in seemingly neutral criteria:

\begin{abstract}
Although the practical result of the conventional [equality] analysis may be that individual claimants are accommodated and the particular discriminatory effect they experience may be alleviated, the larger import of the analysis cannot be ignored. It bars courts and tribunals from assessing the legitimacy of the standard itself....
\end{abstract}

\begin{abstract}
...Although the Government may have a duty to accommodate an individual claimant, the practical result of the conventional analysis is that the complex web of seemingly neutral, systemic barriers to traditionally male-dominated occupations remains beyond the direct reach of the law. The right to be free from discrimination is reduced to a question of whether the "mainstream" can afford to confer proper treatment on those adversely affected, within the confines of its existing formal standard. If it cannot, the edifice of systemic discrimination receives the law's approval. This cannot be right. ${ }^{269}$
\end{abstract}

In the course of the judgment, Justice McLachlin firmly rejects a formal equality approach to human rights and affirms that different treatment is often required to achieve substantive equality. The effect of mere accommodation of differences as "assimilationist" leads the court to revisit and reform the equality analysis of the past to allow greater judicial vigilance over, seemingly, objective criteria. The message is clear: "neutral" job qualifications are not beyond the reach of the law solely because they have become institutionalized through a history of systemic discriminatory assumptions.

In the following passage, McLachlin J. draws upon the recent Supreme Court ruling on equality under the Charter in Law v. Canada (Minister of Employment) ${ }^{270}$ to further elucidate the meaning of equality:

The Court of Appeal suggested that accommodating women by permitting them to meet a lower aerobic standard than men would constitute "reverse discrimination." I respectfully disagree. As this

[1999] 3 S.C.R. 3 [hereinafter BCGSEU].

The use of such standardized tests in both the physical and psychological domains, as a means of excluding non-traditional groups, is widespread and increasingly criticized: W. MacKay \& P. Rubin, Study Paper on Psychological Testing and Human Rights in Education and Employment (Toronto: Ontario Law Reform Commission, 1996).

Supra note 267 at paras. $41-42$.

[1999] 1 S.C.R. 497 [hereinafter Law]. 
Court has repeatedly held, the essence of equality is to be treated according to one's own merit, capabilities and circumstances. True equality requires that differences be accommodated: Andrews, supra, at pp. 167-69, per McIntyre J.; Law, supra, at para. 51, per Iacobucci J. A different aerobic standard capable of identifying women who could perform the job safely and efficiently therefore does not necessarily imply discrimination against men. "Reverse" discrimination would only result if, for example, an aerobic standard representing a minimum threshold for all forest firefighters was held to be inapplicable to men simply because they were men. ${ }^{271}$

These observations about the nature of equality and the use of supposedly neutral criteria to exclude non-traditional groups from particular jobs are valuable in understanding the sometimes subtle processes of exclusion. Such insights are also relevant to the lack of diversity in the Canadian judiciary and the need to examine closely the qualifications for judging in respect to both judges' neutrality and their relationship to the essential nature of the job. In other words, we would suggest that the burden of proof to demonstrate that this is what the current appointments systems actually value is on those who advocate merit. Part III has suggested that this is not what is valued. In short, while professional ability may be one criterion in appointments, it has never been determinative.

At the same time, however, merit is not nothing. There are certainly requirements for the position that cannot be ignored (see Appendix II). Nothing in our argument advocates jobs for the unqualified. Subject to the pool problem to be discussed below, there is likely to be more than enough lawyers who are sufficiently qualified to be judges and who deserve the position. Consequently, the real question is not "meritorious" versus "unmeritorious" candidates, but what we include within our conception of merit that we should positively consider.

\section{ESSENTIALISM ARGUMENT}

Critics argue that by focusing on group identity there is the danger of "implausible essentialism,"272 i.e., that one is assuming a commonality of perspective among a large group of persons that simply cannot be justified. Such an approach ignores the specificity of each person's experience and perspective, and undercuts the fundamental liberal assumption of individual autonomy of members of the marginalized group. ${ }^{273}$ This is closely connected to Hannah Pitkin's celebrated argument against "mirror representation" in legislatures, where she contends that a focus on composition results in an underemphasis on the nature of the job to be done. ${ }^{274}$ In other words, there is no necessary connection between identity and perspective, nor identity and ability. ${ }^{275}$ Support for this argument might be drawn from Greene et al.'s survey where 
"[e]thnicity was not mentioned by a single judge as a cause of differences of opinion about the law...." 276

We agree that there is no necessary connection between one's group identity and one's perspective, but we would suggest that there are contingent connections. This is because one's identity is fluid and transitional, shifting with circumstance. Greene et al. address this when they speculate about the previous comment as follows:

...[W]e suspect that this is because, in fact, ethnicity does not explain differences of opinion among judges from the more long-established ethnic groups. Ethnicity might make a difference, however, if there were a greater proportion of appellate judges from more recent immigrant groups. This is because members of these groups would have lived through the experience of becoming accepted as Canadians and everything that entails - something that longer-established groups took for granted. ${ }^{27}$

Moreover, the nature of the judicial function makes this argument unnecessary. Judges are not meant to be advocates for a particular identity-based group unlike, for example, politicians. But judges are meant to bring wisdom and understanding to the task of judgement and, to the extent that there is a breadth of vision, such breadth can only increase the likelihood of socially sensitive judgement. ${ }^{278}$ As the majority decisions in S.(R.D.) make clear, a judge's experience and context can be a legitimate variable in the decision-making process. ${ }^{279}$

\section{EMPATHY ARGUMENT}

This is the reverse of the essentialism argument. Because there is no necessary connection between identity and perspective, then a "good" judge can come to terms with the perspective of those who have hitherto been excluded; she or he can have "real insight into the plight of the disadvantaged in society." ${ }^{280}$ If a judge can demonstrate strong "intellectual qualities," ${ }^{281}$ listen attentatively, respond empathetically, and perhaps even attend social context judicial education programmes, then she or he can fill in the gap. This is a possible consequence of Professor Nedelsky's "enlargement of mind" argument. ${ }^{282}$

At first blush, this is an attractive argument, because it acknowledges the limitations of identity and the dangers of the authenticity argument, while at the same time acknowledging the importance of diversity. It countenances openness, patience, and self-reflectivity, all of which are important judicial qualities. However, it is flawed in

Greene et al., supra note 67 at 33.

Ibid.

Ifill, supra note 209 at 127.

[1997] 3 S.C.R. 484 [hereinafter S.R.D.]. For further discussion, see R.F. Devlin \& D. Pothier, "Redressing the Imbalances: Rethinking the Judicial Role after R. v. R.D.S." (2000) 31 Ottawa L. Rev. 1.

Greene et al., supra note 67 at 31.

B. Harris, "Appointments to the Bench — the Role of a Judicial Services Commission" (1993) 15 Adelaide L. Rev. 191 at 197-98.

Nedelsky, supra note 233 at 107. 
three ways: first, it assumes a level of understanding that we think is impossible to achieve; second, it slips into paternalism; and third, it is psychologically unpersuasive.

In our opinion, experiences of race, class, and gender are not second order; rather, they are constitutive of our identities. The empathy argument proposes that, as an act of imagination, we attempt to "enter the skin" of another ${ }^{283}$ to see the world through their eyes, ${ }^{284}$ and to step into their shoes ${ }^{285}$ in order to adopt the "relevant social position" of the "least advantaged" in society. ${ }^{286}$ While these are evocative metaphors, we believe that differences are more than constructs of the imagination, though they may be that too. Rather, differences are also hierarchically entrenched, material social practices that circumscribe and constrain our capacities for understanding and comprehension. The unfortunate reality is that Canada is a society pervaded by "deep social cleavages that define permanent minorities." ${ }^{287}$ Consequently, we are not ontologically and experientially transparent. Identities and perspectives are not exchangeable like clothing on a store rack. In short, we are existentially ill-equipped to adequately pursue the needs of the "other." This is compounded when we remember, as we must, that materially, the vast majority of judges come from highly privileged social backgrounds. ${ }^{288}$

Second, the empathy argument makes identity redundant and can result in paternalism because those from the dominant culture are able to do it for, rather than with, people from historically marginalized communities. ${ }^{289}$

Third, and finally, the pursuit of greater judicial representation is, at least in part, a zero-sum game that will require the (partial) removal of privileges from those who have historically benefited. Advocates of the empathy argument require a psychological theory to explain what might motivate the privileged to relinquish such advantage. ${ }^{290}$ This underlying assumption leaves historical power imbalances untouched and, by requiring an argument of greater inclusion, avoids placing the onus on the privileged to explain why less powerful groups have been, and continue to be, excluded.

\section{INDEPENDENCE ARGUMENT}

Because of the essential nature of the judicial task (the adjudication of disputes between two discrete parties), it is argued that judges should be independent of all political forces, be they from the state or from other "special interest" groups. ${ }^{291}$ Representation on the basis of identity confuses the judicial role by converting judges

Wilson, "Women Judges," supra note 59 at 521 . Mendes, supra note 55 at 100.

B. McLachlin, "Judicial Neutrality and Equality" (Paper prepared for Aspects of Equality:

Rendering Justice Conference, Hull, Quebec, November 1995) [unpublished] at 31.

Webber, supra note 217 at 18.

Rawls, supra note 194 at $75,95$.

Williams, supra note 2 at 168.

Greene et al., supra note 67 at c. 2.

Phillips, supra note 29 at 13.

Williams, supra note 2 at 144 .

Schwart, supra note 266 at $480-85$. 
into partisan advocates. ${ }^{292}$ Calls for a representative judiciary are a threat to the cardinal virtue of judicial impartiality. ${ }^{293}$ Indeed, the very idea of representativeness is considered contrary to the judicial oath. ${ }^{294}$

This is a serious argument that gives us cause for significant concern. It is a clear reminder that the functions of legislators and judges are very different: the former are meant to be partisan, the latter are not. However, for several reasons, we think that it fails as a critique of group-based representation.

First, as we have argued in Part II, the mere fact that judges and legislators serve different political functions does not mean that judges are any less political in their assigned sphere of influence; it simply means that the form, forum, and processes of the politics are different. Neither judges nor litigants are ever discrete, individual parties. They are always and already situated in broader social and material circumstances, and their perspectives and disputes are often adversarial concretizations of such circumstances. Judicial decision-making can never float free from such overarching dynamics. In short, judicial independence in this sense - as the equivalent of the apolitical - is a myth. ${ }^{295}$

Second, given the earlier argument as to the extent of judicial discretion, there is always a danger that an individual judge might see the courtroom as a forum for enforcing on others her or his own vision of the world. However, we do not see how the aspiration for group representation necessarily increases that risk. As we have argued in Part IV.A.5, what is desirable is that as many judges be as open as possible to the variety of possibilities that may impact upon a case. Nothing we have argued indicates that a judge is bound by a particular perspective; rather, what we have said is that experience informs understanding. Moreover, as discussed above, we do not consider identity to be a proxy for perspective. Judges exercise a significant degree of autonomy, preferences are rarely firmly fixed, and the scenarios judges encounter are often very particular. ${ }^{296}$ Judicial decision-making often engages with hitherto unanticipated scenarios where there is no necessarily "representationally correct" answer. Moreover, and quite frankly, most of the judges we know are strong-willed and quite opinionated individuals who take individual judicial independence very seriously. It would be naive to think that such characters would operate on the level of knee-jerk reflexes to another's political preferences.

Third, Phillips also makes an important distinction between "advocates" and "deliberators"297 and, to the extent that we have supported the deliberative rationale in Part IV.A.5, we believe that independence is not really under threat. A similar rationale undergirds Vickers' helpful distinction between "speaking for" and "speaking

Harris, supra note 281 at 196; Grant \& Smith, supra note 55 at 81-82; Phillips, supra note 29 at 186.

Ifill, supra note 209 at $97-98,111-12 ;$ O'Sullivan, supra note 188 at 110.

O'Sullivan, ibid.

See also S.R.D., supra note 279 at 504, per McLachlin J. and L'Heureux-Dubé J.

Ifill, supra note 209 at $136-37$.

Phillips, supra note 29 at 162. 
out. ${ }^{298}$ If judges were to adopt the position of advocates, they would be speaking for all the members of their community, which would entail the fallacies and assumptions of the identity determining perspective. In contrast, however, if we conceive of the judge as a deliberator, then she or he can speak out from her or his experience and position. The distinction is between "being there" and "being their."

\section{TRUST/CONFIDENCE ARGUMENT}

It is sometimes suggested that a more representative appointments process will undermine public confidence in the judiciary, because the process will be perceived as abandoning the merit principle. ${ }^{299}$ The fear is that the general public will resent an unjustified politicization of the process.

Our response is simple: the current process in Canada is still not exclusively based on merit. Political partisanship remains a variable, and the professionalization of the process carries with it its own political dynamic. If there is faith by the general public, it may be due to the unjustified secrecy of current processes. As discussed in Part IV.A.1, equality requires more than facially neutral criteria. The underlying considerations and assumptions that inform the process of appointments are often too obscured to assess adequately. We suggest that a better determination of confidence and trust in the system can be acquired through greater transparency and accountability through the creation of independent Judicial Appointment Commissions. This will be further elaborated in Part V. Suffice it to say that legitimacy, purchased by strategies of obscurity and dissimulation, has no place in a democracy.

\section{STIGMATIZATION/TOKEN ARGUMENT}

This argument suggests that group-sensitive judicial appointment procedures can backfire on individual members of historically marginalized communities, because it will be assumed by others that they have only been appointed because of their identity, rather than their individual merit. ${ }^{300}$

This is a worrisome argument. However, to accept this as a rationale for rejecting an inclusionary appointments process as opposed to being a salutary concern is perverse logic: talented minority persons should not be appointed, because prejudiced members of the dominant group will make stereotypical and discriminatory assumptions about them. Moreover, often members from minority groups take pride in their group membership and pride in the fact that their achievements are directly linked to their identity. Thus, to ignore their identity as a response to potential stigmatization, is to ignore the context that gives meaning to their sense of self - a self that they may want valorized. ${ }^{301}$

Vickers, supra note 221 at $28,44$.

O'Sullivan, supra note 188 at 111 .

Grant \& Smith, supra note 55 at 82-83; Cooney, supra note 236 at 42 ; Harris, supra note 281 at 197; Ifill, supra note 209.

Raz, supra note 194 at 71-72. 


\section{DISINTEREST/ABANDONMENT ARGUMENT}

This is an innovative argument along the lines of the law and economics inspired "theory of negative gains." The claim is that if historically under-represented communities are accorded a particular representative status, then those who historically have been privileged no longer need to be concerned about the marginalized; thus, the advantaged are absolved from any sense of obligation, because the historically excluded have their own spokespersons. ${ }^{302}$

On a practical level, we fear that this may be a real possibility; that an increase in the number of judges from historically disadvantaged communities will result in other historically privileged judges abandoning their interest in, or commitment to, such communities. Such a "backing off" might even be encouraged by some members of historically marginalized communities who are concerned about paternalism.

On a normative level, however, this argument is subject to the perversity critique outlined in the previous argument: a negative response from the historically privileged should not be allowed to thwart what would, otherwise, be a positive process. The remedy is to find strategic ways to guard against such abandonment, e.g., through intensified judicial education programmes. Further, considered in light of the arguments supporting greater representation, this fear is also speculative. Greater representation could just as easily increase the deliberative quality of judicial decision-making and, in turn, fuel interest in, and support for, a diversification of perspectives.

\section{RESPONSIBILITY ARGUMENT}

The responsibility argument expresses the concern that group-sensitive appointment procedures may have the unintentional impact of undercutting the individual responsibility of members of historically under-represented groups by creating a "victim mentality."303 It is suggested that rather than taking responsibility for their own situation, members of historically marginalized communities might become excessively reliant on their identity as a proxy for ability. The consequence will be poor quality judicial appointments.

This is a version of the perennial free rider problem. We offer two responses. Given the past record and current appointment processes, we are not convinced that some judges have not secured their positions on the basis of their connections. Secondly, as should be obvious, we do not suggest that identity should be a determinative criterion, but rather one of several important variables. As the later discussion of independent judicial appointment commissions will make clear, a rigorous process of assessment will be required.

303 Williams, supra note 2 at 180, quoting Shelby Steele, The Context of our Character: A New Vision of Race in America (New York: Harper Perennial, 1991). 


\section{OSSIFICATION/ BALKANIZATION/INSTABILITY ARGUMENT}

Those who make this argument are concerned that, by focusing on group identity, there is a danger of overemphasizing our differences and underemphasizing our similarities. Difference becomes ossified, reified, and even fetishized to the exclusion of other vital variables. The result is a diminution of social cohesion, the institutionalization and entrenchment of social cleavages, and the danger of increased social instability. ${ }^{304}$ This could have two negative consequences: judges might be tempted to become advocates for a particular perspective and the judiciary would be rife with factions that provide contradictory interpretations of the actually existing law.

There may be some anecdotal evidence to support this concern. For example, there was a significant amount of media speculation in 1998 that, in the race to fill the position of Sopinka J. there was a lot of "unseemly lobbying" by supporters of the "liberal" John Laskin and the "feminist" Rosie Abella. Similarly, in the 1990s, there were widespread rumours that there was little love lost between Lamer C.J. (as he then was) and L'Heureux Dubé J., and that this sometimes spilled over into their decisions.

The instability problem does not cause us too great a concern. The judicial appointments process has always been intensely political, if perhaps covertly so. Cohesion and stability have always been more apparent than real and, if real at all, purchased only at the price of exclusion. Moreover, our neo-realist theory of law acknowledges that conflict is not only inevitable in a plural and democratic society, ${ }^{305}$ it is also a good thing in so far as it challenges illegitimately entrenched hierarchies. Our own view is that it is better for us to be open about our differences so as to make them both transparent and contestable. ${ }^{306}$ Lastly, as Kymlicka has pointed out in a different context, claims for greater representation (unlike separatist claims) are demands for inclusion; they are an aspiration for full membership in the larger society. In short, they signify "a form of connection,"307 rather than division.

\section{Proliferation Argument}

The concern here is the messiness of implementing group-sensitive appointments procedures. ${ }^{308}$ Questions include: Which groups count? What are the criteria? What are the parameters of difference? Who gets to qualify as a member of a group and on what grounds? Who gets to decide?

This is a serious practical problem. However, as an initial step, it is helpful to distinguish between "historically marginalized social groups" and "interest groups." As Williams points out, the former can be identified based upon immutable or descriptive

Amy, supra note 203 at 131; Kymlicka, supra note 196 at 90; Raz, supra note 194 at 77; Williams, supra note 2 at $80-81,180-81$.

Raz, ibid. at 73.

See also Williams, favouring "expressive" over "suppressive" approaches to politics, supra note 2 at $9,51,53$.

Kymlicka, supra note 196 at $81-82$.

Kymlicka, ibid. at 75-77; Young, supra note 206. 
characteristics that have historically been the cause of discrimination. The latter are based upon more transient and voluntary political choices. ${ }^{309}$ Thus, the characterization of demands for improved representation, as a form of "special interest group" pleading, misunderstands the point. Indeed, in the context of gender, it is simply disingenuous to characterize claims for equitable representation in the judiciary as a "special interest" claim.

More generally, over the last ten years, in a series of cases, the Supreme Court of Canada has been attempting, with some success, to identify the beneficiaries of $\mathrm{s} .15$ of the Charter. With its very first case on s. 15, the Supreme Court of Canada sent a message that not all distinctions on the basis of identity would be offensive to the Charter. In Andrews v. Law Society of British Columbia, ${ }^{310}$ the intended beneficiaries of equality were identified, not only as the expressly enumerated groups, but also as analogous groups who could be described as discrete and insular minorities that experience social and economic disadvantage in society at large. This position was most clearly articulated by Justice Wilson:

[Non-citizens] are among "those groups in society to whose needs and wishes elected officials have no apparent interest in attending" ... I emphasize, moreover, that this is a determination which is not to be made only in the context of the law which is subject to challenge but rather in the context of the place of the group in the entire social, political and legal fabric of our society. While legislatures must inevitably draw distinctions among the govemed, such distinctions should not bring about or reinforce the disadvantage of certain groups and individuals by denying them the rights freely accorded to others.

I believe also that it is important to note that the range of discrete and insular minorities has changed and will continue to change with changing political and social circumstances.... It can be anticipated that the discrete and insular minorities of tomorrow will include groups not recognized as such today. It is consistent with the constitutional status of $s$. 15 that it be interpreted with sufficient flexibility to ensure the "unremitting protection" of equality rights in the years to come."1

In Andrews itself, the Court concluded that citizenship meets the test for an analogous ground under s. 15 of the Charter. It reached this conclusion even though it is not an immutable characteristic like race or gender, with some exceptions. Of course, religion is also a mutable characteristic, but one that has been protected as an enumerated ground of discrimination. In $R$. v. Turpin, ${ }^{312}$ the Court drew the line at province of residence and reinforced this conclusion in $R$. v. $S .(S.) .^{313}$ Unlike citizenship or religion, province of residence can be changed relatively easily. More importantly, province of residence was seen as less likely to subject the relevant group to stereotyping and other forms of discrimination. 
Building upon Andrews, the Supreme Court has expanded the analogous grounds to include common law spouses in Miron v. Trudel, ${ }^{314}$ and gays and lesbians in Egan $^{315}$ and Vriend. ${ }^{316}$ In reaching these conclusions, the Court relied upon the historical disadvantage of groups such as non-citizens, common law spouses, and gays and lesbians. Many other groups who made claims to the benefits of s. 15, such as corporations, were denied. ${ }^{317}$ In its most recent pronouncement on S. 15 in Law, ${ }^{318}$ the Supreme Court summarizes its approach to equality to date, including a workable distinction between groups deserving of the protections of $s$. 15 of the Charter and those that are not.

While the purposes of being represented on the bench may differ from being included in the protections of s. 15 of the Charter, the point is that workable distinctions can be made between groups who are deserving of inclusion and those that are not. It also seems to us that the language of discrete and insular minority and democratic marginalization may be useful reference points for determining who should be represented on the Bench, as well as encompassed in the equality protections of the Charter. The common point is to give people who have generally been denied a voice in the majoritarian legislative process, an effective voice in the judicial arena.

This suggests that, while the articulations of the proliferation argument are likely to be an ongoing challenge, this is not an intractable problem. We are already well on our way, if we follow the basic principles of Charter interpretation.

\section{POOL/EXPERTISE PROBLEM ARgument}

Again, this is a practical argument: even if one wanted to engage in group-sensitive appointments processes, there is not a sufficient number of qualified applicants from the identified communities. ${ }^{319}$ Central to this argument is the claim that legal decision-making requires specialized expertise that is in short supply. Poor quality appointments will only compound the problem and potentially backfire.

There can be no doubt that expertise is an indubitable qualification. But the elements of that expertise are rarely concretely identified. Moreover, there is no necessary correlation between one's expertise as a practising lawyer and one's potential as a judge; there is no evidence available to indicate that the former is a good predictor of the latter. However, we want to emphasize that law-making is more than technique; it entails engagement with some of the most controversial social practices and policies of our community. Narrow professional credentialism, while important, cannot be allowed to trump other important judicial virtues.

\footnotetext{
$314 \quad$ [1995] 2 S.C.R. 418.

31s Supra note 73.

316 Ibid.

317 See e.g. Dywidag Systems International, Canada v. Zutphen Brothers Construction, [1990] 1 S.C.R. 705; Re Aluminum Co. of Canada v. Ontario (1986), 55 O.R. (2d) 522 (Div. Ct). See also P. Hogg, Constitutional Law of Canada, 3d ed. (Scarborough: Carswell, 1992).

$318 \quad$ Supra note 270.

$319 \quad$ Grant \& Smith, supra note 55 at 83.
} 
Moreover, in many of Canada's social policy-making institutions, especially government bureaucracies, the expertise defence has not been determinative. There have been extensive efforts in the public sector to diversify the workforce for positions that are just as complex as that of judge, even if they are not perceived as the social equivalent. ${ }^{320}$ Even the private sector is expected to strive towards greater inclusion through compliance programmes. ${ }^{321}$ Again, expertise arguments, while relevant, are not determinative.

Having said this, we acknowledge that there may indeed be pool problems. Given the history of systemic discrimination and the difficulties involved in achieving success and credibility in the legal community, it would be surprising if there were not a pool problem. But the nature and extent of the pool problem will be relative; each of the identified communities is likely to be quite different. Given the demographics of practicing lawyers, the recruitment of suitable women is likely to be less difficult than the recruitment of First Nations candidates. So again, while proportional representation is desirable, it may not be readily achievable. Consequently, we recognize that weak appointments are likely to do as much harm as good.

At the same time, however, we suggest that while the limited pool is a likely problem, it will probably not be the problem that some critics claim. If we abandon some of the traditional exclusionary appointment practices and develop a more open and inclusionary process, we predict that the gap between supply and demand will be smaller than opponents of proportional representation might argue. For example, although there are significant differences between Canada and South Africa, it should be noted that despite concerns about the pool problem, between 1994 and 1998, 43 of the 91 appointments to the Constitutional Court were from historically excluded groups. ${ }^{322}$

\section{SUMMARY}

From this review of the various arguments for and against a proportionally representative judiciary, it is apparent that we come down in favour of increased diversity. But we have also been careful to point out that identity is not everything, and that there are a variety of goods to be pursued when contemplating the criteria for judicial office. Identity cannot be determinative; its historical devaluation should not be remedied by an essentialist over-evaluation. As Anne Phillips has pointed out in a different context, we need to work toward a balance between the "what" and the "who" rather than subordinating one to the other. ${ }^{323}$ This is what is attempted in the next section as we review the various options for improved judicial appointment procedures.

See e.g. Canada, Human Resources Development Canada, Annual Report: Employment Equity Act, 1998 (Ottawa: Minister of Public Works and Government Services Canada, 1998) for a comprehensive breakdown of statistical representation of historically under-represented workforce groups, including women, aboriginal persons, persons with disabilities, and visible minorities. Employment Equity Act, S.C. 1995, c. 44.

K. Malleson, "Assessing the Performance of the Judicial Service Commission" (1999) 116 S. Afr. L.J. 36 at 46 [hereinafter "Assessing the Performance"].

Phillips, supra note 29 at 5, 25 . 


\section{From THEORY TO INSTITUTIONAL DESIGN: Options for JUdicial APPOINTMENT Processes}

\section{A. INTRODUCTION}

Reforming the judicial appointment process is not a novel idea, but one with a significant historical pedigree. In Appendix IV, we present a bibliography of prior reform proposals which, while not exhaustive, gives a sense of the continuing interest in judicial appointments and reform of the process. ${ }^{324}$ In analyzing these prior reform proposals, we discovered that very few of these reforms have been implemented. Although the original system of Executive Appointment has been modified by the addition of advisory committees and the reduction of absolute executive discretion, the essential features of the appointment process for judges has remained unchanged. This is true even in spite of some quite specific reform proposals, including some changes to the process for appointing judges, as early as the Victoria Charter round of constitutional reform; ${ }^{325}$ the flurry of writing and reform proposals prior to the 1982 amendments to the constitution in the form of the Constitution Act, $1982 ;{ }^{326}$ and the failed rounds of constitutional amendments in the form of the 1987 Meech Lake Accord and the 1992 Charlottetown Accord. ${ }^{327}$

These past proposals for reform did not, until very recently, even raise the issue of representation for women, visible minorities, and the disabled. This issue has only made it to the table of reform proposals in the late 1980s and early 1990s, after the arrival of the Charter and a growing awareness of the politics of identity at all levels of public life, including the judiciary. ${ }^{328}$ These calls for reform did not move beyond academic writings to become specific reform proposals within the inner circles of politics. There has been a growing awareness of the need for a more open and accountable judicial appointment process and a concern about leaving judicial appointments to the unfettered discretion of the executive level of governments. It was in response to the growing demands for a more open and consultative process that the federal government and the provinces embarked on a process of advisory committees involved in screening and recommending appointments to the executive. ${ }^{329}$ Ultimately, the decisions remain in the hands of the executive but, in practice, the recommendations of these advisory committees have increasing weight.

Due to the linguistic disability of the authors (we are unilingual English), we have not tapped the significant writing in French from Quebec proposing judicial appointment reform.

"Victoria Charter" in Constitutional Conference, The Constitutional Review 1968-1971: Secretary's Report (Ottawa: Canadian Intergovernmental Conference Secretariat, 1974) (Secretary: H.F. Davis) 373 [hereinafter "Victoria Charter"].

In spite of adding the Charter, and thus changing the judicial role, no changes were made to the appointment of judges.

Both of these documents contained proposals increasing the provincial role in federal judicial appointments.

"Reform Implications," supra note 64; Grant \& Smith, supra note 55; Mendes, supra note 55. See e.g. Canadian Department of Justice, A New Judicial Appointment Process (Ottawa: Minister of Supply and Services, 1988). This move to advisory committees at the provincial and territorial levels is discussed in Part III and detailed in Appendices II and III. 
Most of the earlier reform proposals did not deal with the issues of proportional representation, which are our concern. Some academics did express concern about the definition of specific qualifications and criteria for appointment, but, in general, there was a view that the process, in spite of its structural flaws, did produce a highly qualified judiciary. In a similar vein, there was little concern expressed about the need for continuing education of judges once they were appointed. Our impression is that concerns about openness and accountability had more to do with appearances and legitimacy, than with the production of a more highly qualified bench. Even the reformers seemed to concede that Canada was generally well served by the results of the existing appointment processes for judges.

The major issues of concern included the following: a proper French/English balance in the federally appointed courts; regional representation in federally appointed courts; the constitutional status of, jurisdiction of, and representation on, the Supreme Court of Canada; a proper provincial role in federal appointments, especially to the Supreme Court of Canada; and, the problem of judicial appointments based upon political patronage. It was this last issue of political patronage that led to a reduction of the unfettered discretion of the executive in making judicial appointments. ${ }^{330}$ While it would be naive to suggest that the political patronage factor has been completely removed from the judicial appointment process, its significance has been somewhat reduced. ${ }^{331}$

In our opinion, it is inevitable that a judicial appointments process will be political, and so the challenge is to make it a better and more democratic political process, one that is more inclusive and more accountable. Identity criteria are legitimate political criteria. There is also a need for a more open and accountable process for appointing judges who, as discussed earlier, are significant political actors.

There is a tendency in most reform proposals to assume that "one size fits all." We want to suggest that reform proposals should be context-specific. Two sets of variables are important. First, there are different types of courts, both institutionally and constitutionally. Thus, in the ensuing discussion, we will on occasion make distinctions between 1) the Supreme Court of Canada, 2) other s. 101 federal courts, 3) s. 96 courts, and 4) provincial courts. Moreover, in the context of provincial courts, given the demographics of each province, variations might well be desirable. Second, the various groups that have been historically excluded are differently situated and, therefore, may need different remedies in the pursuit of a more representative judiciary and a more

CBA Committee Appointment, supra note 119 and Special Committee on the Appointment of Judges, Judicial Selection in Canada (Toronto: Canadian Association of Law Teachers, 1987). These two reports along with many articles mentioned in Appendix IV referred to patronage as a major problem to be addressed in order to make the appointment process legitimate and restore confidence.

331 Our view in this regard, as well as that of many others who write about judges, was confirmed by former Nova Scotia Chief Justice Lorne O. Clarke in a May 31, 1999 interview with the authors. He also expressed the view that the quality of judicial appointments has improved over the years. $\mathrm{He}$ also asserted that merit is the only proper basis for appointments to the Bench, but agreed that candidates from non-traditional backgrounds bring additional qualifications to the task of judging. 
open and accountable appointment process. ${ }^{332}$ As we assess the various options, the challenge will be to "strike the right balance between demophilic hopes and demophobic anxieties" ${ }^{333}$ for the particular function fulfilled by the Canadian judiciary.

\section{B. The Constitutional Framework}

Any changes to the process of judicial appointments in Canada must either operate within the existing constitutional framework or be accompanied by the necessary constitutional amendments. As we know from the failed efforts at constitutional amendment in 1987 (The Meech Lake Accord) and 1992 (The Charlottetown Accord), it is difficult to change the Constitution under the amending formula introduced as part of the Constitution Act, 1982. Most reforms require the approval of the federal government and seven provinces, representing at least 50 percent of the population. ${ }^{334}$ This is further complicated by the fact that changes to the composition (which would probably not be read to include the process of appointment) of the Supreme Court of Canada require the unanimous consent of the federal government and the provinces. ${ }^{335}$ The difficulties of constitutional amendment to the appointment process for the Supreme Court of Canada are accentuated by the view that this Court is implicitly entrenched in our constitutional structure, and any changes to it may have constitutional dimensions. ${ }^{336}$ Finally, the practice of putting proposed constitutional amendments to both federal and provincial reference adds a further hurdle on the path to constitutional change.

The judicial structure in Canada is set out in the Constitution Act, 1867, and there have been no significant changes to the relevant sections since Confederation. ${ }^{337}$ The judicature sections of the Constitution Act, 1867 are ss. 96-101 dealing with, among other things, the federal appointment of judges. Under s. 96, the executive branch of the federal government is given the power to appoint superior district and county courts in the provinces. ${ }^{338}$ These courts themselves are provincially created and regulated under s. 92(14) of the Constitution Act, 1867 which reads as follows:

The Administration of Justice in the Province, including the Constitution, Maintenance, and Organization of Provincial Courts, both of Civil and of Criminal Jurisdiction, and including Procedure in Civil Matters in those Courts. ${ }^{339}$

See also Phillips, supra note 29 at 167.

Unger \& West, supra note 194 at 13.

Constitution Act, 1982, supra note 66, s. 38.

Ibid., s. 41 .

W.R. Lederman, "Constitutional Procedure and the Reform of the Supreme Court of Canada" (1985) 26 C. de D. 195.

(U.K.), 30 \& 31 Victoria, c. 3, reprinted in R.S.C. 1985, App. II, No. 5.

Most (if not all) provinces have abandoned district or county courts or merged them into the superior courts of the province. These superior courts at the trial level, are courts of inherent jurisdiction and appeal courts created under statute.

Supra note 337. 
The procedure at the criminal level is determined federally under s. 91(27) of the Constitution Act, 1867 , but both federally and provincially appointed courts can deal with substantive matters of criminal law. Indeed, Canada has a unified court system in which courts, regardless of who appoints them, can deal with both federal and provincial issues. ${ }^{340}$ The superior courts in the province are federally appointed in accordance with s. 96 of the Constitution Act, 1867, and the rest of the provincial courts are appointed in accordance with s. 92(14).

Under s. 101 of the Constitution Act, 1867, the federal government has additional powers to create courts "for the better administration of justice" and to staff those courts. This section reads as follows:

The Parliament of Canada may, notwithstanding anything in this Act, from Time to Time provide for the Constitution, Maintenance, and Organization of a General Court of Appeal for Canada, and for the Establishment of any additional Courts for the better Administration of the Laws of Canada. ${ }^{341}$

It was under this section that the Supreme Court of Canada was created as a general court of appeal in 1875 . The Supreme Court is still a statutory court regulated by the Supreme Court Act. ${ }^{342}$ Section 101 also provides the basis for appointments to the Federal Courts and the Tax Court, which are exceptions to the unified court structure in that they deal only with matters of federal law.

In respect to s. 96 superior court appointments by the executive, the process is set out in the Constitution Act, 1867, and any change to this would require constitutional amendment. However, as long as the formal appointment was left with the Governor in Council, a constitutional amendment would not likely be needed to move the real power to a different source. The current modifications of the executive appointment process by advisory committees have been instituted without any constitutional amendment. Thus, reforms such as public hearings or even an appointing commission may be instituted without constitutional amendment, so long as the formal act of appointment is left with the Governor in Council. Support for this analysis is provided by the move to making judges accountable for misconduct to the Canadian Judicial Council, created under the Judges $A c t,{ }^{343}$ while leaving the formal mechanism of removal as a Joint Address of the Senate and House of Commons in accordance with s. 99 of the Constitution Act, 1867. In this way, change in the effective locus of power for disciplining federal judges was brought about without any constitutional amendment.

Provincially appointed courts, as well as federal ones, deal with important national matters. It is not like the United States, where most important matters are litigated in federal courts, which deal only with federal matters and not state matters.

341 Supra note 337.

342 R.S.C. 1985 , c. S-26. There are arguments that the Supreme Court is also implicitly entrenched in the Constitution. 
Because the Constitution is silent with respect to federal appointments under s. 101 of the Constitution Act, $1867^{344}$ and provincial appointments under s. 92(14), the processes for these appointments are left to the relevant federal and provincial statutes. These statutory structures have also adopted a system of executive appointments, recently modified by advisory committees. Thus, any changes to these appointment processes can be brought about by regular statutory change, rather than by constitutional amendment. Only the s. 96 appointments to superior courts, and possibly Supreme Court of Canada appointments, raise constitutional issues. This is another reason why proposals for reform of the appointment process must be put in their proper contexts and adapted to different situations.

\section{Options}

There is a broad continuum of judicial appointment models from which to draw. Charted from the least to the most open process, systems could range from complete executive discretion in appointments to direct popular election of judges - and any variation or combination of those in between. We will survey some of the commonly recommended methods of judicial appointment and will evaluate their appropriateness for the Canadian judiciary, and their effectiveness in pursuit of the goal of proportional representation and a more open and responsive appointment process.

While we wish to focus our attention on realistic reform proposals that can be implemented, we are aware that there is a vast array of options; some of which, while not politically practical, serve to define the potential parameters of change. It is important, in thinking about options for change, not to restrict analysis to traditional modes - in common parlance, to allow for thinking outside the box. It is with this in mind that we turn by way of introduction to two options that are neither politically feasible nor recommended. The purpose of their consideration is to define the range of options and to expose some of our assumptions about what is a legitimate judicial appointment process.

\section{LOTTERY}

At first blush, this might appear to be an extreme suggestion. But we want to make two points; one that highlights the current situation, another that looks to the rationale underlying lottery systems.

First, if the research of quantitative social scientists and Judge Seniuk ${ }^{345}$ are accurate, then our judicial system is significantly less objective and more arbitrary than we might want to believe. For example, Heard concludes his study of Supreme Court of Canada decisions by claiming that the "outcome of Charter cases litigated in the

With the possible exception of the implicit entrenchment of the Supreme Court of Canada mentioned earlier. This may give a constitutional dimension to Supreme Court appointments as well. 
highest court of the land appears to be something of a lottery based on which judges sit on a panel. ${ }^{346}$

Second, if what we have, in fact, is a lottery system, why not consider designing a rational lottery? Essentially, a lottery is an application of the jury principle, the democratic belief that decision making should represent the broad cross-section of community opinions. ${ }^{347}$ Statistical representation designed to elicit a representative sample of the community is an ancient principle and practice that can be traced back at least as far as Athenian society. ${ }^{348}$ In many ways, this is an antidote to the current elitist conception of the judicial office, one that comes close to a cult of expertise veiled in a mythology of reverence and deference.

Under a lottery system, there might be a serious danger of weak appointments. Therefore, it might be suggested that judicial appointments under such a system be for a limited term (perhaps five or ten years) so as to provide for turnover and to prevent institutional sclerosis. This would also have the positive side effect of avoiding judicial burnout. ${ }^{349}$ However, such short-term appointments would also have some significant disadvantages.

An obvious objection to this suggestion is that limited-term appointments might result in an undermining of judicial independence and neutrality, insofar as judges may be influenced by considerations about future prospects. It would also not provide for one of the pillars of judicial independence: security of tenure. Indeed, this aspect of the judicial role has been considered so important in Canada that it is guaranteed in s. 99 of the Constitution Act, 1867 for superior court judges and in statutory form for most other judges appointed at both the federal and the provincial levels. ${ }^{350}$ Thus, a lottery system of appointment challenges some of our basic assumptions about the nature of the judicial role, e.g., that security of tenure is a vital aspect of an independent and impartial judiciary.

If the disadvantages of the lottery proposal outweigh the advantages, there is an alternative. Lawyers with ten years standing could apply to a Judicial Appointment Commission that would distinguish between qualified and unqualified candidates. Once a list was compiled, as positions became available, the lottery principle would be applied. This increased scrutiny would justify the traditional long-term appointments and ensure security of tenure. We acknowledge that such a suggestion is a political non-starter. Our point in raising it, however, is to demonstrate the contingency and possible weaknesses of the assumptions underlying current arrangements and the

\footnotetext{
346 Heard, supra note 62 at 305.

347 For a discussion of the lottery principle in the broader democratic context, see J. Burnheim, Is Democracy Possible? The Alternative to Electoral Politics (Berkeley: University of California Press, 1985). Ibid. at 9-12.

The suggestion for limited term appointments is not unprecedented. See Justice Report, supra note 257 at $21-23$.

Thus any system of appointment for superior court judges that did not guarantee security of tenure would require a constitutional amendment.
} 
advantages of at the very least considering other possibilities. ${ }^{351}$ It also reminds us that as a society, we value something more than narrowly defined merit, that there are other complicating factors that are worthy of legitimate consideration.

\section{REPRESENTATION QUOTAS}

More realistic than the lottery option, discussed above, is a system of representational quotas as a way of producing a more diverse judiciary. It is a more politically realistic option because it would merely be an additional feature of either a modified executive appointment system (the current structure) or an appointment commission, as we later propose. A quota system would also be an extension of some conventions and practices of current judicial appointment processes.

Under the Supreme Court Act, ${ }^{352}$ there is a guaranteed quota of three justices from Quebec. This quota was also included in the failed 1992 Charlottetown Accord and the 1987 Meech Lake Accord. Had it passed, the quota would have become constitutionalized. There is also a practice or convention of regional representation on the Supreme Court of Canada that has rarely been breached. ${ }^{353}$ By this convention, there is one justice from Atlantic Canada, two from the West, and three from Ontario. These informal regional quotas are also applied in respect to other s. 101 courts, such as the Federal Court and the Tax Court, either by way of convention or by statutory provisions. ${ }^{354}$ At the provincial level, similar conventions and practices are sometimes applied to ensure that different regions of the province are represented on the bench. While regional representation has not been conveyed in terms of express quotas, the practice has achieved much the same results. ${ }^{355}$

Once we move beyond regional or linguistic ${ }^{356}$ representation to other matters of identity such as race, gender, or disability, the issue of quotas in any form becomes more controversial. It is useful to pause and consider why there is such resistance to recognizing the need for representation on the judiciary in respect to some aspects of identity and not others. ${ }^{357}$ At the heart of this resistance are assumptions about merit

For further discussion of the possibilities and benefits of lottery systems, see Burnheim, supra note 347 at 110-19, 156-60.

332 Supreme Court Act, supra note 342, s. 6.

333 W.R. Lederman, "Thoughts on Reform of the Supreme Court of Canada" (1970) 8 Alta. L. Rev. 1 at 11, advocates regional quotas with increased representation for the Alantic and Western provinces.

See Federal Court Act, R.S.C. 1985, c. F-7, s. 5(6); Tax Court of Canada Act, R.S.C. 1985, c. T-2, s. 4(4). See also Appendix II, infra.

In addition, a similar practice has developed in Germany and Switzerland. However, the quotas are based on partisanship rather than region. See infra note 371 and accompanying text.

356 By "linguistic," we of course, mean the official languages of French and English, rather than other linguistic groups in Canada such as aboriginal.

357

A partial explanation for why French representation is accepted unquestionably is the Canadian history surrounding bilingualism and biculturalism, and the constitutional guarantees in ss. 16-23 of the Charter. See Mahe v. Alberta, [1990] 1 S.C.R. 342, where French minority education rights under $\mathrm{s}$. 23 were seen as an exception (or at least an acceptable deviation) to $\mathrm{s}$. 15 equality rights and s. 27 recognition of multiculturalism. Further, the Supreme Court expressly advocated a 
and impartiality in judging that influence what is considered a legitimate appointing process and what is not. We have responded to these issues in Part IV.

Many of these problems can be traced to the use of the term "quotas." Within human rights circles, the focus has shifted away from quotas (which can be counter-productive for the cause of equality) to realistic equity programs based on target representation over a reasonable period of time. ${ }^{358}$ However, whatever term is used, opponents tend inevitably to attack the process in terms of quotas and the associated negative connotations of "affirmative action," "reverse discrimination," and so on. To most, fixed quotas smack of a kind of tokenism, whereby positions must be filled, regardless of merit and without taking account of the number of candidates in the available pool. Accordingly, we use "quotas," even though we advocate it in terms of more modern equity targets and timetables that broaden the definition of what constitutes merit, rather than diluting the job qualifications for judges.

In the context of the judiciary, some commentators believe that a representative judiciary means judges from minority groups will be biased if they attempt to act as "representatives." 359 Perhaps the more serious ramification, however, would be the perceptions of using quotas, which are often accompanied with negative connotations and attitudes. The dangers could be the result of perpetuating discriminatory assumptions about historically marginalized groups, and the ultimate goal of representativeness would become the target for attack rather than encouragement. ${ }^{360}$ Lastly, as illustrated with the analysis of different justifications and oppositions to representation in Part IV, the goal of diversity is inherently complex, and imposing quotas may be a blunt and simplistic solution. More apt for facilitating increased diversity would be a preference model, a self-examination model, or increased outreach, some of which are presently used in certain Canadian provinces. ${ }^{361}$

However, quotas might still be a good example of how different remedies may have to be tailored for different communities. Because of some aspects of the proliferation problem (particularly in the context of race: who gets to count as a minority person and which minorities qualify?) quotas may be unmanageable. ${ }^{362}$ However, gender is significantly less complex, though not unproblematic, and therefore potentially more amenable to a quota system. But this does not mean that ethnicity should fall off the

constitutional right for proportional representation (although not threshold representation) of a French minority on school boards that governed schools including French language education. Beyond the limited guarantee in S. 35 of First Nations peoples' aboriginal and treaty rights, there is no similar protection for First Nations' language or culture.

This is closer to what is advocated to improve gender representation by Grant \& Smith, supra note 55.

See e.g. Sir H. Gibbs, "The State of the Australian Judicature," as quoted in S. Shetreet, "Who will Judge: Reflections on the Process and Standards of Judicial Selection" (1987) 61 Aust. L.J. 766 at 777; Harris, supra note 281 at 196.

We are not saying that the possibility of backlash should be used as a justification for the nonimplementation of quotas, only that the issues are complex and would require a great deal of commitment from all those involved to be utilized effectively.

For a discussion, see Cooney, supra note 236 at $39-41$.

Phillips, supra note 29 at $168-69$. 
map; perhaps a schedule of targets and timetables needs to be developed and critically pursued. ${ }^{363}$ To some extent, the decision whether to pursue quotas will also be dependent upon the pool problem. For example, we would suggest that there are probably enough qualified women in the pool to pursue a quota system, but probably not enough senior Aboriginal lawyers who fit the usual minimum qualifications of ten years of practice. This is an illustration that one size does not fit all.

Our exploration of lotteries and quotas as largely unrealistic political options for change, does reveal some of the underlying assumptions about what constitutes a legitimate judicial appointments process. Many of these assumptions about the nature of the judicial process have been discussed earlier. Before turning to more politically viable options for change, it is useful to consider the current appointment process as the reference point for change. This current process has been explored in detail in Part III of this article and will not be repeated here. Suffice it to say that at most levels the process of executive appointment has been modified by advisory councils and the unfettered discretion of the past somewhat reduced.

\section{MODIFIED EXECUTIVE APPOINTMENT}

This is basically the current system for the Canadian Supreme Court, where the government has broad discretion in appointment. Although aided by advisory bodies, the other federal and provincial appointments are still subject to executive discretion in varying degrees.

Canada inherited its executive appointment system from Great Britain, which has always entrusted the executive branch of government with the power of appointment. However, like most jurisdictions, Britain has not escaped the call to reform the appointment process. This is not to say that past appointees have been unqualified or remarkably below standard. Indeed, the tradition of appointing barristers rather than solicitors - a division not present in Canada - often ensured candidates were chosen from the professional and highly esteemed, but elitist, ranks of the Queen's Counsel. However, this exclusionary practice, the closed process, and unrepresentative bench is still the cause of serious criticism. As a result, recent movement has occurred in the Lord Chancellor's office towards greater openness and diversity. For example, solicitors may now apply, vacancies are advertised, candidates are sometimes interviewed, and process and criteria are now published. However, the Lord Chancellor still maintains the right to recommend an individual who has not undergone the application or screening process. ${ }^{364}$ Within the senior judiciary, women and ethnic minorities are still radically under-represented relative to their numbers in the population and in the profession. Despite the above reforms, the Lord Chancellor has explicitly articulated a commitment to ensure appointments based on "merit ... regardless of gender, ethnic Departmental Report 1999-2002, Chapter 3: Judicial Appointments (London: LCD, 1999), The Lord Chancellor's Department, online: <http:/www.open.gov.uk/cd/deprep9902/repchap3.htm \#judapp> (date accessed: 15 August 1999). 
origin, marital status, sexual orientation, political affiliation, religion, or disability." 365 It is noteworthy that before the Labour Party was elected in 1997, it proposed the establishment of a Judicial Appointments and Training Commission to open up new opportunities to under-represented groups. Several months later, however, the Lord Chancellor announced that the Commission would be put on hold while other reforms took place. ${ }^{366}$ In December 1999, the backtrack was completed when the Lord Chancellor rejected plans for further significant changes, but instead appointed a Commissioner to "monitor" the system. ${ }^{367}$ However, the lobby for greater reform and the establishment of a judicial appointment commission is still attracting widespread support. $^{368}$

Thus, not only is the British process and its numerical effects unamenable to greater representation, but it has been ill-fitted to the political and territorial realities of Canada. Historically, the major objection to executive discretion in Canada was the exclusion of the participation of provincial governments from appointments to the Supreme Court of Canada and s. 96 courts. Allowing only the federal level appointment power was seen as contrary to the very concept of federalism, but allowing collaboration between the federal and provincial executives was seen as a legitimate exercise. ${ }^{369}$ The power of appointment would still remain within the discretion of the executive, the only question was which executive. Later, calls for greater openness and transparency arose, this time in the name of democracy instead of federalism. ${ }^{370}$

As a matter of reform, the question is whether the modifications to executive appointment (in the form of advisory committees and the setting of criteria for appointment) can be further extended to achieve better representation from traditionally excluded groups and a more open and accountable process of judicial appointments. It is true that the changes to the structure have advanced both objectives to some extent. However, they have not gone far enough. While the diversity of the bench has grown, ultimately it depends on the political will and commitment of the particular government

U.K., Lord Chancellor's Department, Judicial Appointments: The Lord Chancellor's Policies and Procedures (London: LCD, 1999), online: <http:/www.open.gov.uk//lcd/judicial/appointments/ jappinfr.htm> (last modified: 20 March 1999).

366 G. Drewry, supra note 364 at 2-3.

367 C. Dyer, "Old Boy Network Survives in Appointment of Judges" [Manchester] Guardian Weekly, (9-15 December 1999).

Drewry, supra note 364; K. Malleson, "A British Bill of Rights: Incorporating the European Convention on Human Rights" (1999) 5 Choices 21 at 36.

These reform proposals usually dealt with the Supreme Court of Canada, although the federal appointment power over section 96 courts was also controversial. See e.g. Quebec, Report of the Royal Commission of Inquiry on Constitutional Problems, v. 1-5 (Quebec: Province of Quebec, 1956) (Chair: T. Tremblay, J.); Canada, Final Report of the Special Joint Committee of the Senate and of the House of Commons on the Constitution of Canada (Ottawa: Queen's Printer, 1972) (Cochairs: G.L. Molgat \& M. MacGuigan). This was also the rationale underlying the failed constitutional amendment proposals - the Meech Lake Accord and the Charlottetown Accord. See e.g. "Reform Implications," supra note 64; CBA Committee on Appointment, supra note 119; Judicial Selection in Canada, supra note 204. 
in power, ${ }^{371}$ and ultimately the advances in gender representation have far outdistanced those on race or disability. Some of this can be explained in terms of qualified pools, but some is no doubt due to the greater numbers of women, as well as to their past successes in the pursuit of equality rights. This suggests the need for greater distance from the executive process and leads us to suggest that more significant changes in the process are required.

Advisory committees have made the judicial appointment process more open and accountable, but as we have argued in Part III.D.3, the composition of these committees is still quite limited. Their membership is drawn largely from the professional ranks of lawyers and judges, and there is only limited input from the lay public. The representation of women, visible minorities, and the disabled within this lay membership is also limited. Thus, the accountability (such as it is) is still to a fairly select and elite group. Furthermore, the process is still one which is veiled in secrecy, and the existence and composition of these advisory committees is not readily available to the general public. As long as the ultimate decision rests with the executive, it is unlikely that the process of recommendation and advice will be open. In sum, we do not see much hope for significant reform in tinkering with the current, albeit improved, executive appointment process. ${ }^{372}$ As will be argued later, what is required is an independent body that actually makes the decision.

\section{ELECTIONS}

The premise of the election model is to allow the populace a voice in choosing its judges, especially once the political role of the judiciary is recognized. The major justification for an elective model is that the current executive appointment system is highly partisan, secretive, and unaccountable. ${ }^{373}$ Seen as its opposite, elections are perceived as making judges accountable to the electorate, either through the voters directly (partisan or non-partisan popular election) or through the public's political representatives (legislative election of judges). However, each has its own strengths and weaknesses.

The best examples of legislative judicial elections are found in Germany and Switzerland, although a handful of American states also employ this method. For the German Constitutional Court, the Bundestag, which consists of elected political representatives, and the Bundesrat, the house which represents the member states, each

For example, in Ontario, the profile of the provincially appointed judiciary became significantly more diversified under the Liberal and N.D.P. administrations of the late 1980 s and early 1990s. However, with the election of a Conservative government, there has been a significant decrease in the number of women and visible minorities appointed.

372 J. Smith, "Executive Appointment of the Judiciary: A Reconsideration" in Appointing Judges: Philosophy, Policy and Practices (Toronto: Ontario Law Reform Commission, 1991) at 189 [hereinafter "Executive Appointment"] provides an example of small changes to the existing structure. A Place Apart, supra note 15, provides some examples of somewhat broader limits on executive discretion, as an extension of the current system. 
elects eight judges to the court by a two-thirds majority. ${ }^{374}$ The judges of the Swiss Federal Supreme Court are elected in a meeting of joint session by the House of Representatives and the House of the States. Each has institutional mechanisms for ensuring that satisfactory candidates are selected. For example, in Germany, splitting the selection power between the Houses and the two-thirds, rather than the simple majority, encourages the selection of judges satisfactory to all parties. Similarly, the Constitution of Switzerland mandates that the Court is representative of all three official languages of the country. ${ }^{375}$ The legislators also participate in the recruitment and nomination of candidates, rather than merely approving or rejecting a candidate through a vote. ${ }^{376}$ Interestingly, though, both share the same flaw: the judicial seats on the Court are usually distributed proportionately to the relative strength of the major parties in power in Parliament. ${ }^{377}$ Thus, partisan politics still play an important role in selecting judicial officers in both countries.

Popular elections are most often associated with various states in the United States. Due to its obvious democratic nature, the election process has some significant advantages. Judges are made accountable for their policy choices; voters are informed about the candidates, especially with the use of party labels; the voter turnout for judicial elections is fairly large when they are co-ordinated with other political contests; and finally, poor judges are voted out instead of sitting on the bench until retirement due to security of tenure. ${ }^{378}$

One might think that given our politicized conception of judging and our commitment to a more democratic process, we would favour an election model in that this would promote accountability, openness, and public participation. However, we do not recommend the election model.

First, as we have argued, although courts and legislatures are both political entities, the functions that they fulfill are still somewhat discrete. In our view, legislators are best conceived of as delegates, they are responsive and directly accountable to their electorate. Judges, however, are more like trustees. Because there are relatively weak mechanisms of accountability, society relies on the judiciary on an act of faith. The ideal is that judges will attempt to reach decisions as independently of external forces as possible. The danger is that if judges have to face (re)election, then they will be

C. L'Heureux-Dube, "Nomination of Supreme Court Judges: Some Issues for Canada" (1991) 20 Man. L.J. 600 at 615 [hereinafter "Nomination"].

Federal Constitution of the Swiss Conferation, adopted on 29 May 1874 [The Constitution of Switzerland].

D.M. Beatty, Talking Heads and the Supremes: The Canadian Production of Constitutional Review (Agincourt, Ontario: Carswell, 1990) at 259.

See E. Blankenburg, "Changes in Political Regimes and Continuity of the Rule of Law in Germany" in H. Jacob et al., eds., Courts, Law, and Politics in Comparative Perspective New Haven: Yale University Press, 1999) 249 at 265-66; The Swiss Federal Supreme Court, The Judges, Their Background and Their Assignment, online: Government of Switzerland <http://www.supreme-court.ch/e/bger/judges.htm> (date accessed: 21 August 1999).

H.R. Glick, Courts, Politics, and Justice, 3d ed. (New York: McGraw Hill, 1993) at 116-21. 
excessively influenced by considerations of popular support. ${ }^{379}$ This is compounded by concerns about the impact of financing for judicial campaigns and a lack of public knowledge about the judicial system, judicial practices, and the qualifications of individual judges beyond their party stripe. ${ }^{380}$

Second, although we favour democracy, we do not reduce democracy to a simplistic model of majoritarianism. Democracy is a complex phenomenon and includes other principles, most importantly for our purposes, the advancement of the participatory rights of historically marginalized groups. ${ }^{381}$ Viewed in this light, majoritarianism via elections can be a threat to democracy. ${ }^{382}$ Indeed, there are some studies from the United States which indicate that, from the perspective of the promotion of minority rights, electoral processes are more reactionary than bureaucratic processes. ${ }^{383}$ Election on the basis of a majority vote by definition excludes the interests of the minority population in judicial election districts, and legislative election is often seen as giving the power of appointment to a small group of political elites. ${ }^{384}$ Specifically, it has been suggested that in the United States, appointed judiciaries are more open to historically excluded groups than elected judiciaries. ${ }^{385}$ Similarly, a recent study of European systems suggests that the appointment system is one of the reasons why women "make up the majority of new judges in France and Italy, and are in increasing numbers in other countries." 386

Third, election systems are becoming less popular in the United States, ${ }^{387}$ in part because they seem to undercut the legitimacy of the judicial system. Judicial independence is often compromised, either at the will of popular opinion or because of political pressures. Desirable judicial candidates may be discouraged from running and subjecting themselves to a potentially "demeaning" experience. ${ }^{388}$ The election of judges, "it is believed, would be incompatible with their role as a bulwark against

For a brief discussion of some of the American literature in this regard see $\mathrm{J}$. Blume \& $\mathrm{T}$. Eisenberg, "Judicial Politics, Death Penalty Appeals, and Case Selection" (1999) 72 So. Cal. L. Rev. 465 at 466. See also S.P. Croley, "The Majoritarian Difficulty: Elective Judiciaries and the Rule of Law" (1995) 62 U. Chi. L. Rev. 689 at 727-28. Abrams, supra note 221; Croley, ibid. at 730-39.

This expanded conception of democracy being more than majoritarianism is clearly articulated by the Supreme Court of Canada in the Quebec Secession Reference, supra note 81.

Croley, supra 379.

For discussion, see Young, supra note 206 at 131-32.

In the three states that use legislative selection, past membership in the state legislature is often the key to success. These candidates are favoured about 80 percent of the time. Further, selection from this select political network often reflects the homogenous nature of the state legislature. See H.R. Glick, supra note 378 at 122-23.

Croley, supra note 379 at $\mathbf{7 8 4 - 8 6 .}$

Thomas, supra note 195 at 7.

U.K., Lord Chancellor's Department, Research Series no. 6/97, "The Use of Judicial Appoinment Commissions: A Review of the U.S. and Canadian Models" (Discussion Paper) by K. Malleson, (London: Her Majesty's Stationery Office, 1997) at 55, 64.

C. Kendall, supra note 258 at 217. 
majoritarian excesses, concerned more with protecting individual interests than with pursuing communal goals."389

Fourth, the realities, as opposed to the ideal, of the American system are less than encouraging. Many judges are initially appointed by the governor to fill vacancies occurring between elections. Then, due to little competition, judges are usually reelected uncontested until they retire, which usually occurs between elections so that the governor may appoint a new candidate and allow the process to repeat (for those states which hold retention elections). Relative to partisan elections, voter turnout for nonpartisan judicial elections is lower and voters are poorly informed on the specific qualifications of candidates, since the campaign promises are fairly constant from candidate to candidate - to be fair and just, to avoid conflicts of interest, to improve the court's efficiency, and so on. Unless an incumbent receives an unusual amount of negative publicity, it is extremely rare for him (most candidates are "typically white, middle-aged men who dress in conservative business suits"390) to be voted out of office. Although judges running in partisan elections are somewhat more likely to be voted out of office since voters are more likely to cast ballots for a party slate than an individual judge, it has other negative effects such as partisan influence in decisionmaking. In addition, good judges are often removed from office by the electorate if a new political party is favoured. ${ }^{391}$

Finally, as a matter of realpolitik, the idea of judicial elections generates very little interest or support in Canada. ${ }^{392}$ All of the foregoing strongly suggests that judicial elections are both inappropriate and unlikely to occur in the Canadian political climate.

\section{CONFIRMATION PROCEDURES}

Whereas the judicial elections option is usually rejected outright, the idea of confirmation hearings has been supported recently by Jacob Zeigel and retired Supreme Court Justice Gérard La Forest, ${ }^{393}$ at least with regard to the Supreme Court. In fact, support for such a reform came as early as 1969 from high-ranking political and academic commentators. ${ }^{394}$ The allure of this model is that it provides greater transparency and provincial participation. Public confirmation hearings by the Upper House - the Senate as representative of the provinces - opens the process to the

Webber, "The Limits to Judges' Free Speech: A Comment on the Report of the Committee of Investigation into the Conduct of the Honourable Mr. Justice Berger" (1984) 29 McGill L.J. 369 at 379 .

Ibid.

Ibid.

See e.g., Judiciary in Canada, supra note 15 at 108.

J. Ziegel, "Merit Selection and Democratization of Appointments to the Supreme Court of Canada" (1999) 5:2 Choices 1. See also Task Force on Canadian Unity, A Future Together: Observations and Recommendations (Quebec: Minister of Supply and Services Canada, 1979) (Co-chairs: J.L. Pepin \& J.P. Roberts); The Constitutional Committee of the Quebec Liberal Party, A New Canadian Federation (Montreal: Quebec Liberal Party, 1980); Bill C-60, The Constitutional Amendment Act, ? Sess., ? Parl., 1978.

39

P.E. Trudeau, The Constitution and the People of Canada (Ottawa: Govemment of Canada, 1969);

P.H. Russell, "Constitutional Reform of the Canadian Judiciary" (1969) 7 Alta. L. Rev. 103. 
people, provides a check on executive power, and allows the provinces a voice in judicial appointments to the court that adjudicates intergovernmental disputes. However, leaving aside logistical problems regarding the need to reform the Senate, there are other drawbacks to a confirmation or ratification model of appointments.

While the need to check executive discretion is understood and advocated here, partisan politics are still likely to be the soft underbelly of the confirmation model. ${ }^{395}$ If the same political party holds most of the seats in the Lower and Upper Houses, then patronage may still be a strong factor in appointments. On the other hand, even if that is not the case, the process may still be riddled with politics, e.g. if the Senate reacts to public opinion and the media about the appointee rather than to her or his qualifications. ${ }^{396}$ Further, "ideological partisanship" may also occur; if it is thought that the nominee would unacceptably "shift the philosophical balance"337 on the Court, then one's personal philosophy becomes a condition of appointment. This could backfire on the goal of representation; the status quo as the favoured norm might encourage greater homogeneity in the Court appointees, rather than diversity.

Second, there is little reform in the initial stages of recruitment and screening which precedes the nomination. ${ }^{398}$ So, not only may well-qualified candidates be discouraged from participating, but also many well-qualified individuals may not even be considered. Further, the choice is limited - approve or reject - which is obviously an ineffective "merit-control" method; ratification would provide "only for the avoidance of downright poor nominations; it does not provide for positively seeking out the best available nominees in the first place." ${ }^{399}$ To an extent, diversifying the bench becomes the ultimate responsibility of the nominator. For example, in the United States, the President is responsible for nominating an appointee, and there were great differences in the demographics of appointments with the last three Presidents. Carter was firmly committed to redressing the under-representation of women and minorities, and nearly one-half of nominees were female, Black, and/or Hispanic during his administration. In contrast, the affirmative action policies were abolished by Reagan and the numbers dropped drastically. Most recently, the Clinton administration has renewed Carter's commitment resulting in about 64 percent of nominees being women or minorities by mid-1997..$^{400}$ Thus, there are many unstable variables that tend to affect a confirmation model: partisanship, ideological preference, and personal commitment of a single body which nominates. ${ }^{401}$

G. Winterton, “Appointment of Federal Judges in Australia" (1987) 16 Melbourne U.L. Rev. 185 at 195.

"Nomination" supra note 374 at 621.

Ziegel, supra note 393.

Kendall, supra note 258 at 219.

W.R. Lederman, "Current Proposals for Reform of the Supreme Court of Canada" (1979) 57 Can. Bar Rev. 687 at 698.

See Glick, supra note 378 at 148-49; H.J. Abraham, The Judicial Process, 7th ed. (New York: Oxford University Press, 1998) at 31.

There have been other reform proposals involving the legislative branch of government in either confirmation hearings or more direct screening and selecting of judges. Beatty, supra note 376 at 257-71 calls for legislative rather than executive appointment of judges. A. Keller, "Guarding the Guardians: Pressures for Reform to the Supreme Court Nomination Process" (1994) 25 R.G.D. 283 
Third, the principles outlined in Valente on the distinguishing characteristics of the judiciary ${ }^{402}$ may be violated since a candidate is often asked to indicate how she or he would decide on a specific issue. While some do not answer, if they do, they face the public perception of bias on their part (judicial impartiality), and, if they are appointed, the moral dilemma of whether they are required to conform to that opinion (judicial independence). It is for this reason that former Justice of the Supreme Court of Canada, Bertha Wilson, is opposed to confirmation hearings, drawing on the experience of Sandra Day O'Connor, who was interrogated at great length about her views on abortion in the United States. ${ }^{403}$ Retired justice Peter Cory has expressed the same misgivings. ${ }^{404}$

Finally, the parade of American horribles, such as the Bork and Thomas debacles, has provided much ammunition against the idea of confirmation hearings. Irresponsible questioning or reporting could possibly destroy the credibility and reputation of a candidate and discourage many from even considering judicial office. ${ }^{405} \mathrm{~A}$ balance needs to be struck between government secrecy and media circus frenzy. We believe that this can be achieved through transparent and responsible appointment commissions, the model to which we now turn. ${ }^{406}$

\section{TOWARDS A "TRIPLE P" Judiciary: JUdiCiAL APPOINTMENT COMMISSIONS}

This may be the option with the fewest drawbacks. ${ }^{407}$ It is submitted that the creation of independent judicial appointment commissions would interject accountability, transparency, and representativeness into the present system, while keeping in step with the Canadian tradition that finds the idea of a "confirmation mess" somewhat repugnant. ${ }^{408}$

calls on Parliament to confirm executive appointments. J-Y Morin, "A Constitutional Court for Canada" (1965) 43 Can. Bar. Rev. 545 calls for appointments for the Supreme Court of Canada to be made by the Senate. Both the 1987 Meech Lake Accord and the 1992 Charlottetown Accord advocated a role for a reformed Senate in judicial appointments, the latter also proposing an Aboriginal voice in Supreme Court appointments through an Aboriginal Council of Elders. All of these reform proposals were in respect to appointments to the Supreme Court of Canada and not other courts.

Valente v. R, [1985] 2 S.C.R. 673.

"Methods of Appointment," supra note 230 at 162.

K. Makin, "Top-court Judge Defends Bench" The Globe and Mail (3 March 1999) A5. Canada, Minister of Justice, Constitutional Reform - The Supreme Court of Canada by O.E. Lang (Ottawa: Canadian Unity Information Office, 1978) at 2.

Note also that Ziegel uses the South African experience to justify his case for confirmation hearings, but the process used is actually a Judicial Services Commission which holds public interviews, a small yet crucial difference, and something upon which we will focus in the next section.

While there is some support for appointment commissions among academics, Beatty, supra note 376, rejects this option as too professionally focused and too bureaucratic. As will become apparent, we have designed the commissions to minimize such dangers. To be clear, we are not suggesting that the powers of an organization like a judicial council be further expanded. We are advocating the creation of an innovative independent administrative agency that has one function only, to make appointments.

W.R. Lederman, supra note 399 at 699. Former Chief Justice Bora Laskin has also expressed his support for a system of judicial appointment commissions. 
The origins of judicial appointment commissions are normally traced to the so-called "Missouri plan." The name of the committee process in the United States illustrates the fundamental value underlying the concept: it is a "merit commission." Appointments are to be based on merit and professionalism, rather than political or ideological partisanship. The result of an American study shows that politics does still play a role with nominating commissions, however, this is still less of a role than with pure executive discretion. Candidates are also ensured to be well qualified for appointment. ${ }^{409}$ We believe the prevalence of traditional partisanship would further decrease by granting appointing power to the commission and further restricting the discretion of the executive appointing body. However, as advocated throughout this article, the concerns of proportional representation must also be addressed in formulating a responsible and democratic judicial appointment process.

Thus, the proposed Judicial Appointment Commission would be given appointing power and its procedures and structures would have significant public dimensions. Its existence should be as independent as possible from the government. Constitutional entrenchment, as there is in Israel, might be an option, although this may not be practical, as previous attempts to constitutionalize the Supreme Court and its appointment procedures have failed. Constitutional amendment may be avoided by leaving the formal appointing power with the Governor in Council. In addition, the ideals of transparency, accountability, and representation are vital factors to be embedded in the process. The present system, as well as the various options considered above, lacks these democratic fundamentals. But these broad principles are only the tip of the iceberg; in truth, the devil is in the details. We do not claim to have refined every element of our proposal but we do provide enough detail about a workable option to open a constructive conversation about meaningful change in appointments processes. To concretize our proposal, we will structure our argument around four points: statutory status, composition of the commissions, the process, and criteria for appointment.

\section{A. Statutory Status}

The following elements of the appointment process should be published in government statutes - or at a minimum, in regulations - rather than in policies or guidelines:

- Creation of the Judicial Appointments Commission;

- Composition of the Commission;

- Appointment process;

- Criteria for judicial appointment, including a commitment to the need for diversity;

- Obligation to maintain statistics;

- Obligation to publish an annual report. 
We see no reasons why, in a democracy, the various elements of the appointment process should not be statutorily defined. ${ }^{410}$ This would cover the existence, composition, and procedures of the appointing commission, the criteria for judicial appointment, and the obligation to maintain statistics and to publish an annual report. Statutory codification would not only enhance certainty and openness; it would also symbolize the significance of the commitment to democratic processes.

As discussed in Part III, no jurisdiction in Canada contains a comprehensive account of the process in statutory enactments. A few include the composition of the committee and the provision for an annual report. Two describe the process and criteria to a limited extent, but no jurisdiction includes the obligation to maintain statistics. The vast majority of the procedures and processes currently in place merely operate on the level of policy. This checkerboard approach presents many difficulties for the realization of independence, transparency, accountability, and representation.

A constitutionalized process would appear to be the ideal means of generating independence for an appointing commission. However, due to the practical problems associated with constitutional reform in the past, we fear that this would make our proposal unrealistic. Moreover, it may be that constitutionalization is undesirable, because it might freeze the process when demands and needs change over time. Consequently, we suggest that appointing commissions should be granted a statutory status akin to other independent administrative agencies, such as the Canadian Human Rights Commission. ${ }^{411}$ If given an arms-length statutory status, the independence of the appointing commission can be better assured.

Further, the barriers to information on the appointments process which exist in some jurisdictions result in inevitable problems with transparency and accountability. Statutory delineation of the process has an educational function, as well as process value and substantive importance. Policy guidelines are inherently more difficult to obtain than published statutes and regulations, which are required to pass through the appropriate democratic stages. Concomitant with the democratic process is the binding legal obligation on government to comply with and support its own legislation. Of those jurisdictions that support increased diversity in the judiciary, only two have legislated the goal: Ontario and the Yukon. Whereas both include diversity among the criteria for appointment, the wording is also important; the former requires "a recognition of the desirability," and the latter mandates the "need" for diversity as a primary criterion. We prefer the wording of the Yukon statute, because it exceeds a mere recognition that diversity on the bench is a "good" thing. By employing stronger wording, greater accountability and legitimacy is possible.

The epitome of the lack of transparency in the current regime is illustrated by the difficulty in gaining access to raw numbers. In many jurisdictions, the government does 
not maintain, or at least does not release, statistics on members from ethnic or racialized communities or persons with disabilities. The express justification is individual privacy. However, there are at least four counter-arguments. First, there is a coherence objection: what is the nature of the distinction between gender and other identity-based criteria that justifies statistics on gender, but not race, ethnicity, disability, marital status, etc.? Second, the purpose of these statistics is positive: to evaluate whether any progress is being made. ${ }^{412}$ How is the federal government to know if it is achieving its stated "commitment to appoint more women and representatives of Canada's ethnic and cultural minorities to the bench"413 if it refuses to maintain statistics? Third, other elements of government and even the private sector have to maintain such statistics (for example, under the federal contractors programme). Why should the judiciary be exempt? Fourth, other jurisdictions that also take privacy seriously, such as the United States, South Africa, and the United Kingdom, maintain and circulate comprehensive statistics. ${ }^{414}$ By including a strong statutory commitment to maintain statistics and to pursue diverse appointments, and with the publication of an annual report to track the Commission's progress, the government can be held accountable through democratic processes, something which is currently extremely difficult (if not impossible).

The obligation to publish annual reports ${ }^{415}$ would ensure detailed accounts of the Commission's achievements and the explicit identification of demographic information. It would also provide a public forum for commissions to suggest further reforms based upon their experiences. For example, jurisdictions experiencing difficulty in diversifying their bench because of low turnover rates might wish to contemplate recommending the creation of early retirement incentive programmes, or perhaps even more controversially, a reduction in the retirement age. Furthermore, perhaps an organization like the National Judicial Institute could compile and synthesize the annual reports from each of the jurisdictions so as to provide a national database on judicial appointments processes, criteria, and statistics.

\section{B. COMPOSITION}

In the previous section, we advanced the argument that a checkerboard approach to statutory status is problematic. However, regarding the actual composition of the commissions, we do believe it is necessary for effective representation to tailor and accommodate their make-up as is appropriate for each level of court and jurisdiction. Although the Supreme Court of Canada and the Federal and Tax Courts were all constituted under s. 101 of the Constitution Act, 1867, there are significant institutional and functional differences and responsibilities which merit a separation of commissions for appointment. While all three are federal courts in the strict sense, the Supreme Court of Canada is also federalist as its general jurisdiction is much broader. It can hear

Ibid. at 26, 85. Canadian Bar Association, Working Group on Racial Equality in the Legal Profession, Racial Eguality in the Canadian Legal Profession (Ottawa: Canadian Bar Association, 1999) at 23.

$413 \quad$ Supra note 129.

$414 \quad$ Justice Report, supra note 257; S. Goldman, Picking Federal Judges (New Haven: Yale University Press, 1997) at 350; "Assessing the Performance," supra note 322 at 46. 
appeals from all regions in Canada and from all traditions including common law, civil law, and aboriginal law. Thus, the representation of provincial interests is vital for appointments to this court. This is not necessarily the case for other $\mathbf{s} .101$ courts. By the same token, there is little need for federal participation in the appointment processes for provincial courts. The suggested breakdown for all levels could be as follows:

\section{Supreme Court of Canada}

- The Chief Justice or designate member of the Court;

- A representative from the Canadian Bar Association;

- A representative from the federal government;

- A representative from the federal opposition;

- A representative from the relevant provincial or regional ${ }^{416}$ government;

- A representative from the relevant provincial or regional opposition;

- A dean of law or designate;

- Eight lay persons who encompass the diversity of Canadian society (including regional, cultural, linguistic, racial, and gender diversity, especially, for example, in relation to First Nations peoples, bearing in mind not only proportional representation, but also threshold representation):

- Women would make up a minimum of 40 percent of the Commission

- Quebec representatives would make up a minimum of 35 percent of the Commission.

\section{Federal Court of Canada and Tax Court of Canada}

- The Chief Justice or designate member of the relevant court;

- A representative from the Canadian Bar Association;

- A representative from the federal government;

- A representative from the federal opposition;

- A dean of law or designate;

- Six laypersons who encompass the diversity of Canadian society (including regional, cultural, linguistic, racial, and gender diversity, especially, for example, in relation to the representation of regional interests and First Nations peoples, bearing in mind not only proportional representation, but also threshold representation):

- Women would make up a minimum of 40 percent of the Commission.

\section{Section 96 (federally appointed) Courts}

- The Chief Justice or designate member of the relevant court;

- A representative from the Canadian Bar Association;

Certain details would need to be worked out regarding provincial governmental representation for regional appointments from Western and Atlantic Canada. A possible method would be to alternate representatives between those provinces when an appointment from that region arises. This could ensure greater consistency in the present practice of judicial distribution of seats on the Supreme Court by region. Alternatively, for greater flexibility, a practice of consultation could be employed. Overall, however, we believe that the inclusion of a provincial voice is conducive to greater cooperation between the levels of government. 
- A representative from the relevant provincial Law Society;

- A representative from the federal government;

- A representative from the federal opposition;

- A representative from the relevant provincial government;

- A representative from the relevant provincial opposition;

- A dean of law or designate;

- Nine lay persons who encompass the diversity of Canadian society (including regional, cultural, linguistic, racial, and gender diversity, especially, for example, in relation to First Nations peoples, bearing in mind not only proportional representation, but also threshold representation):

- Women would make up a minimum of $\mathbf{4 0}$ percent of the Commission.

\section{Provincial or Territorial Courts}

- The Chief Judge or Senior Judge of the relevant court or a designated member;

- A representative from the Canadian Bar Association;

- A representative from the Law Society;

- A representative from the provincial government;

- A representative from the provincial opposition;

- A dean of law or designate;

- Seven lay persons who encompass the diversity of Canadian society (including regional, cultural, linguistic, racial, and gender diversity, especially, for example, in relation to First Nations peoples, bearing in mind not only proportional representation, but also threshold representation):

- Women would make up a minimum of 40 percent of the Commission.

Other practical matters with the functioning of the Commissions must be addressed. Each commission will select its own chair and the process of appointments (outlined in the next section) will also apply to all elevations and transfers between courts. Each member will have a five-year ${ }^{417}$ staggered part-time position on the Commission, renewable for one term only. However, turnover at various other times is foreseeable due to changes in judicial or governmental offices. Lastly, laypersons will be paid on a per diem basis for their service on the Commission.

Before proceeding to explain why we have chosen this breakdown in compositional structure, it is first necessary to respond to potential counter arguments on the practical implementation of this proposal. The foregoing commissions consist of $15,13,17$, and 13 members respectively, which, with the exception of the 13-person committee in Ontario, is exceptionally large compared to the current size of advisory committees in Canada. However, it is useful to note that South Africa's Judicial Services Commission is composed of 23 members and has thus far encountered few problems; in fact, it is seen to have worked very well in the appointment process. ${ }^{418}$ This example, though, leads to another counter-argument. The South African Commission deals solely with

\footnotetext{
417 This is not an arbitrary number. Five years as an appropriate term is comparable to the term of office for government. Further, this number is guaranteed in s. 4(1) of the Charter under the heading of Democratic Rights. See also IPPR Report, supra note 410 at 259. 
appointments to the Constitutional Court, whereas the workload for appointments to provincial or superior courts in Canada could be more demanding. This speculation is easily refuted by the South African experience itself. As we pointed out previously, between 1994 and 1998, ninety-one appointments were made to the Constitutional Court. Further, the proposed commissions in Canada would be aided by small secretariats to decrease the administrative workload of members, and smaller subcommittees can be used during the preliminary stages of the process for expediency. For larger jurisdictions, such as Ontario and Quebec, the regional system currently in place can be continued, but modified to comply with the basic principles we recommend. Lastly, and most importantly, the significance of the commission's role should not be undermined by potential administrative technicalities. As discussed in Part II, the judicial office is vitally important to the functioning of Canadian society, and measures must be implemented to ensure legitimacy and accountability in appointments. One such measure is to provide adequate representation in the composition of the commissions.

The foundational rationale for our proposed composition is to ensure that no one group has a monopoly over appointments. As democrats, we believe that there are a number of legitimate stakeholders in a judicial appointment system: the judiciary, the legal profession, politicians, and the general public. Consequently, we propose a system of checks and balances designed to give an effective voice to all these constituencies, but a veto power to none. ${ }^{419}$

Given the importance of expertise and credibility amongst one's peers, clearly, there must be representation from the judiciary and the bar. Canadian jurisdictions which already employ an advisory committee system provide for this, although in many American jurisdictions the number of judges is severely limited. Some commentators have suggested that the presence of the Chief Justice or Chief Judge on the committee could result in undue weight given to one individual's opinion. ${ }^{420}$ However, the South African experience has proven that this fear is merely conjecture. Indeed, there have been a number of instances where the ultimate selection has not been in accordance with the views of the "head of the court." 421 Further, as the Chief Justice also acts as the administrator of the court, it is vital that her or his input is considered seriously. It should also be noted that we have not recommended that the Chief Justice or Judge necessarily chair the commission. Thus, we have given one seat to a judicial representative of the court to which the appointment is to be made. ${ }^{422}$

See also Harris, supra note 281 at 205.

See e.g. J. Ziegel, "Merit Selection and Democratization of Appointments to the Supreme Court of Canada", supra note 393 at 11.

"Assessing the Performance," supra note 322 at 38.

In terms of the bench, Thomas has found that "the continental experience suggests that involving lower-ranking judges in the appointments process may encourage an increase in the appointment ... of women, minorities and those individuals from non-traditional educational backgrounds": Thomas, supra note 195 at 7 . While we have been tempted to suggest that representatives be nominated from the ranks of both the senior and junior judiciary, due to the size of the commissions, we have decided to recommend the nomination of only the Chief Justice/Judge or designate. 
In terms of the bar, a seat is provided for a representative of the Canadian Bar Association on each commission, as well as an additional seat for a representative of the relevant provincial Law Society on the s. 96 and provincial court commissions. The designation of each representative is to be dealt with institutionally and poses no real problems, as this is already an accepted part of the current system.

However, there must be more than simply representatives from the bench and bars for this would simply be a "self-selecting oligarchy." "23 Thus, we have given a seat to a dean of law or her or his designate. ${ }^{424}$ This recommendation endeavours to address concerns of accountability. Although she or he has significant ties to the legal community, a dean of law can also play an important watchdog function. Moreover, as an academic, the decanal representative can ensure that the commission is informed of current research on appointment matters.

The presence of political and lay members is likely to be a debated issue. The idea of an independent commission, at first glance, seems at odds with allowing political representatives a voice on the commission. However, to ensure a balanced membership and increased accountability, there must be some legislative representation. We have removed the discretionary power of cabinet, but we recognize that judicial office is a form of political office and, consequently, there must be some representation from democratically constituted bodies. Studies of European appointments commissions suggest that legislative representation may increase the "connection between political factions and judges." ${ }^{25}$ However, this may be because legislative representation is given too prominent a role. Therefore, to prevent hostage-taking and to expand the conception of representation beyond traditional party-driven definitions, political representation too should be of a limited number. Government and opposition representatives are granted equal seats to allow for an adequate range of partisan political views. We acknowledge that there may be potential problems with political bartering between party representatives. This type of quid-pro-quo exchange has been illustrated by the German and Swiss experiences, where an understanding is present that appointees will be chosen in proportional numbers to legislative political representation. One method of overcoming this is to grant only a limited number of seats and to ensure that other voices are heard on the commission. Consequently, we have recommended that there be only one representative from each of the relevant governing and official opposition parties. ${ }^{426}$

Lay membership is sometimes seen as a significant move in improving the degree of public participation in the appointments process. ${ }^{427}$ In contrast, one commentator contends that no one person can "represent the public," only her or his own views or

R. Stevens, "The Independence of the Judiciary: The Case of England" (1999) 72 So. Cal. L. Rev. 597 at 622.

We derive this idea from the South African example. See "Assessing the Performance," supra note 322 at 38.

In South Africa, the political representatives constitute the majority of the committee. "Assessing the Performance," ibid. at 38.

lbid.

Harris, supra note 281 at 205-206; Greene et al., supra note 67 at 196. 
that of the government if appointed by it. ${ }^{428}$ All existing Canadian judicial appointment committees have rejected this counter-argument. We have attempted to further separate the present proposal from this objection by providing a relatively nonpartisan method of appointment for lay members. Each would be appointed by an allparty committee of the relevant federal and/or provincial government and appointed by an order-in-council. This would allow a move away from strict partisan appointments to the commission, yet allow adequate screening of the abilities of the individuals. Lastly, the process of an all-party committee is more transparent than informal arrangements currently used and may provide a better mechanism to achieve the stated commitment of diverse representation on the commission.

However, we also acknowledge other options for ensuring the independence of lay members, which may be seen by some as questionable if appointed by any government body. For example, in the Yukon, it is at the discretion of the committee to appoint an additional lay person if the current make-up of the council does not sufficiently reflect the diversity of the community. By putting all lay appointments in the hands of the other committee members, worries about partisanship on the committee could be modified. Nevertheless, given our position on the fundamentally political and social role played by judges in Canadian society, we prefer the former method, as it merges all branches of government (the executive, legislative, and judicial) in a vital part of the appointments process. ${ }^{429}$

Just as important as bench, bar, and lay representation is identity-based representation. ${ }^{40}$ For example, The American Judicature Society proposes that "all appointing authorities shall make reasonable efforts to ensure that the commission substantially reflects the gender, ethnic, and racial diversity of the jurisdiction;" ${ }^{431}$ we would also include express recognition of the need to include First Nations, persons with a disability, and a conceptually broad definition of cultural representation. Gender is relatively straightforward - a fair balance between the sexes ${ }^{432}$ - but the criteria for other historically marginalized groups are more difficult. In this respect, it may be helpful to consider Kymlicka's distinction between threshold and proportional representation. ${ }^{433}$ The concern here is that proportionate representation for a small minority (e.g. First Nations peoples) will mean that, in reality, there will be very few representatives, so that ultimately their participation will be merely symbolic, rather than substantive. Consequently, what might be required is threshold representation, that

J. Smith, supra note 372 at 209.

Perhaps an even better method would be to have laypersons nominated by "constituent assemblies," i.e. non-conventional participatory fora designed to circumvent the vicissitudes of conventional partisan politics. For a discussion see A. Dobrowolsky, "Radically Rethinking Representation: Towards More Imaginative and Inclusive Institutions" (forthcoming). Moreover, this may be a good example of why it would not be desirable to constitutionalize the processes. If Canada were to transform its democratic institutions at some future point, statutory changes could more easily modify the appointments system.

IPPR Report, supra note 410 at 258.

Model Selection Provisions (Chicago: AJS, 1994) Art. 2.

W. Mackay \& R. Bauman, supra note 64 at 80 suggested a majority of female members in 1985. However, for greater flexibility, we have chosen at least $\mathbf{4 0}$ percent as sufficient representation. This number approximates a midpoint between critical mass and actual proportional representation. Kymlicka, supra note 196 at $77-78$. 
is, numbers greater than a group's proportion to the population, but large enough to be effective as a presence. ${ }^{434}$ While most easily achieved through the lay appointments, it is important that these concerns are also considered by nominators of legal and political representatives. Identity representation should not be confined by a "quota/de minimus mentality," but should inform the entire process of judicial appointments.

Perhaps the most controversial aspect of our proposal for the composition of the commissions is that lay representatives constitute a majority of the commission. ${ }^{435}$ This is vital for several reasons. First, lay membership acknowledges the fact that there are crucial considerations beyond professional ability that must be assessed, including personal characteristics and human qualities. Second, the bench, bar, and political representatives may be tempted to perpetuate elitist and "self replicating" values that are incompatible with our aspirations for a more democratic system. ${ }^{436}$ Third, it is likely that the professional representatives would dominate an outnumbered lay representation unless there was an effective critical mass, which we believe requires a majority. ${ }^{437}$

Throughout this article, we have suggested that the "professionalization" of the appointment process is an improvement over previous, more politically partisan processes. However, we have also indicated some reservations. It is sometimes assumed by commentators that professionalization is synonymous with depoliticization and is, therefore, incontrovertibly good. This is a mistake. Professionalization does not necessarily displace political variables and values; rather professionalization adds a new set of values and, therefore, a new layer of politics to the appointment regime. ${ }^{438}$ This is so because, as Foucault and the sociologists of knowledge remind us, there are mutually constitutive relations between knowledge and power. ${ }^{439}$ Our concern is that the values priorized by professionalization may become hegemonic, thereby devaluing and excluding other positive variables that are worthy of respect and consideration in a pluralist democracy. Indeed, in a sense, the discourse of professionalization can even be more worrisome than traditional political partisanship because professionalism tends to occult its reliance on contestable value judgments. ${ }^{440}$ It is for this reason that

See also Vickers' discussion of N.A.C.'s adoption of deliberate "overrepresentation" of the most marginalized or disadvantaged women (supra note 221 at 39). The representation of Quebec Judges on the Supreme Court of Canada is an example of an already operational regime of threshold representation.

See also IPPR Report, supra note 410 at 258.

See also Justice Report, supra note 257 at 12.

Ibid. at 28.

438 Baar, supra note 409 at $10,12-15$.

439 M. Foucault, Discipline and Punish: the Birth of the Prison, trans. A. Sheridan (New York: Pantheon Books, 1977) at 27; M. Larson, The Rise of Professionalism: A Sociological Analysis (Berkeley: University of Califormia Press, 1977); K.M. MacDonald, The Sociology of the Professions (London: Sage, 1995); D.W. Rossides, Professions and Disciplines: Functional and Confict Perspectives (Upper Saddle River, New Jersey: Prentice Hall, 1998).

As Burton Bledston has noted, the "'culture of professionalism' seemed ... capable of transcending 'the favoritism of politics, the corruption of personality, and the exclusiveness of partisanship," as cited by W.W. Pue, "Lawyering for a Fragmented World: Professionalism after God" (1998) 5 Int'l J. Leg. Prof. 125 at 126. 
professionalism needs to be counterbalanced by the democratic principle of proportional representation.

\section{Process}

Currently, in Canada, the dominant distinction is between commissions which are purely advisory (those that simply screen names which are submitted to the executive) and those which have a power to nominate a shortlist from which the executive then must make a choice. ${ }^{441}$ We want to emphasize an even stronger distinction: that to be drawn between judicial nomination and appointing commissions. The former simply suggests names to the executive which still retains a large degree of discretion and may appoint a "sympathizer" from the list compiled by the committee. With the latter, however, the committee actually makes the decision. ${ }^{442}$ This is not a completely novel idea; the suggestion for an appointing commission was proposed in Canada in 1985 by MacKay and Bauman, ${ }^{443}$ and the process is currently used in Namibia, ${ }^{444}$ in Israel for all senior courts, ${ }^{445}$ and in South Africa for the Constitutional Court. ${ }^{446}$ Not only is the process premised on greater independence, but the independence of the judiciary itself is also enhanced.

A major criticism of a judicial appointment commission is that the power of appointments is removed from elected representatives and put into the hands of appointed members. Thus, it is said that the problem of accountability is simply relocated rather than resolved. ${ }^{447}$ However, we believe greater accountability could be accomplished by creating a responsible selection process conducted by commission members who represent an equal and broad cross-section of society, government, and the profession (discussed in the previous section) and, through this, by implementing an open and transparent process of judicial appointment. ${ }^{448}$ Our proposed appointing process is outlined in the following flow chart:

Formerly, when the Canadian Bar Association National Committee for the Judiciary was informally involved in the process at the federal level, it did not even have the power to recruit candidates or receive applications. Names were forwarded directly from the Justice Department and the Committee would rate each candidate. Such a system of strict screening alone resulted in many criticisms, including the elite nature of the Committee, its passivity in the process, and its limited ability only to weed out clearly unqualified candidates. Currently, all committees are relatively independent during the recruitment stage.

Harris, supra note 281 at 207.

"Reform Implications," supra note 64.

Harris, supra note 281 at 203.

Israel, Basic Law: Judicature (adopted 38 February 1984); C. L'Heureux-Dubé, "La nomination des juges: une perspective" (1994) 25 R.G.D. 295 at 305.

The Constitution of the Republic of South Africa, 1996, Act No. 108 of 1996, s. 174 (entered into force 4 February 1997).

Constitutional Reform, supra note 405 at 3 . However, this criticism is somewhat dubious, since it is very rare that a government would be voted out of office as the result of a poor appointment. The secrecy which currently blankets the process actually tends to insulate the government from having to account for its appointments.

Y.M. Murray, "The Cultural Implications of Judicial Selection," Book Review of Race-ing Justice, En-gendering Power: Essays on Anita Hill, Clarence Thomas, and the Construction of Social Reality by T. Morrison (1994) 79 Cornell L. Rev 374 at 400-401; "Assessing the Performance," supra note 322. 
Figure 1: The Appointments Process

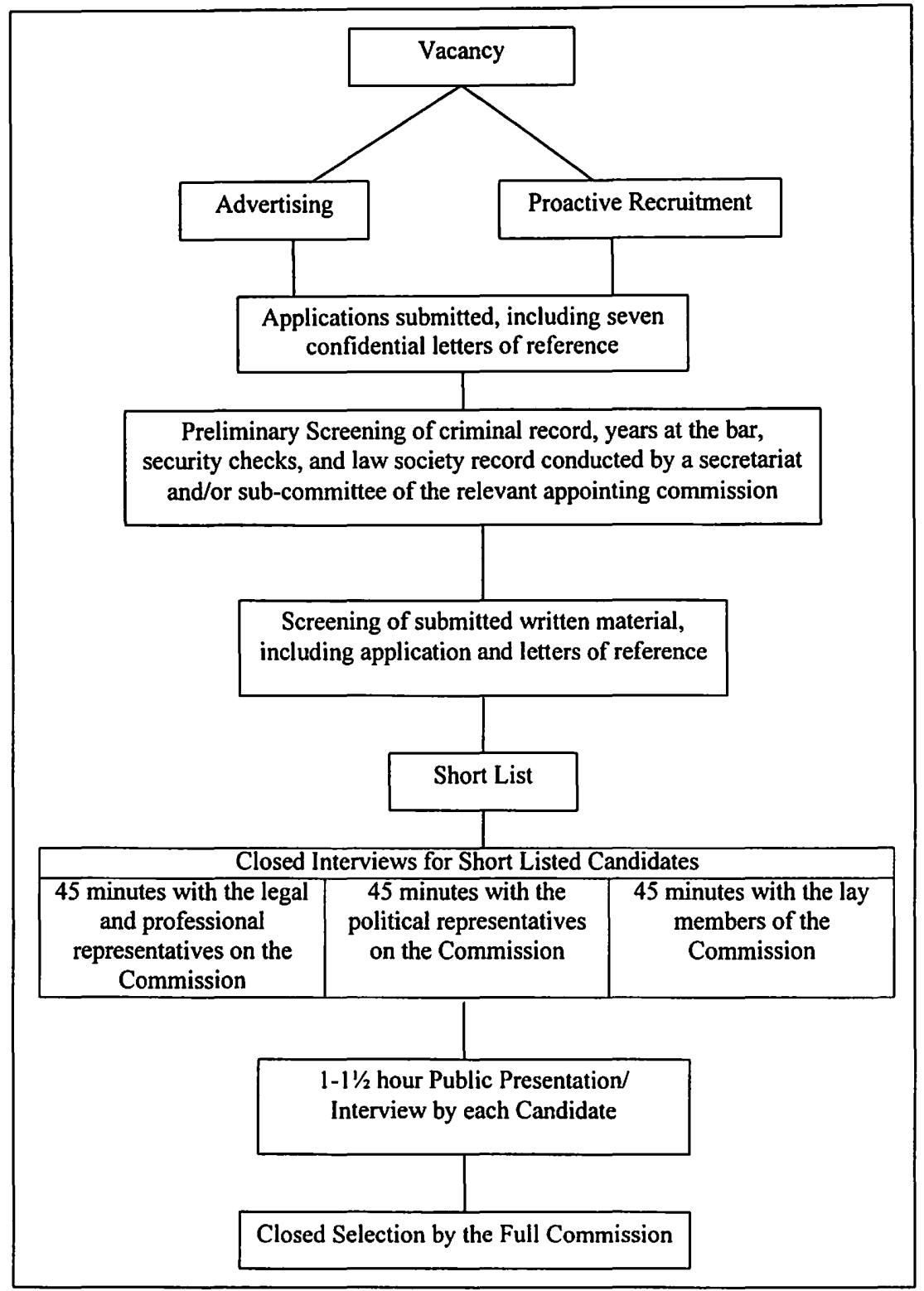


The proposed system mirrors the current stages of application, screening, and appointment in most jurisdictions, but it envisages several vital differences. First, all vacancies are to be advertised, and a proactive recruitment campaign towards underrepresented groups is to be pursued. ${ }^{449}$ It is apparent from past experience in Ontario that such proactive steps are central to increasing appointments from diverse groups. ${ }^{450}$ In addition, there would be a space available for self identification on all application forms, and other methods, such as goals and timetables, could be pursued throughout the preliminary screening stages.

The second difference is perhaps more controversial. Presently, all jurisdictions in Canada employing a commission system maintain all records and proceedings in confidence, although the names of committee members are usually available upon request. This practice can no longer be maintained once appointive power is bestowed upon a commission. Thus, we have decided that the presentation/interview of judicial candidates should be partially open for two reasons. First, candidates' abilities and individuality should be transparent to the public due to the enormous responsibility shouldered by our judges. ${ }^{451}$ Second, bureaucracies are not beyond politics; they too may, intentionally or inadvertently, be motivated by controversial political assumptions and should be held publicly accountable.

Some may think that opening up the process to the degree specified here would, in effect, result in the implementation of confirmation hearings and all the implications associated with them. However, there are distinct differences which must be emphasized. Confirmation hearings function either to confirm or to reject a candidate - each candidate is subject to intense public scrutiny in the legislative arena. In contrast, public interviews are one part of the larger independent nomination and appointing process. Several candidates are interviewed for one position, and those that are not selected do not face the same stigma, since the elimination of candidates is a natural part of the selection process. Further, guidelines for questions may be established to ensure all candidates are treated fairly; the political jockeying occurring in confirmation hearings would not be as intense. Taking the South African experience as an example, while controversial at first, the public interviews are now well-accepted by most, and the Deputy President of the Constitutional Court, who was selected through this process, described it as "useful and ... essential and correct." 452

In addition, the stated function of the interviews in South Africa is primarily to identify positive characteristics of the candidate, rather than to emphasize and inflate negative ones. Any allegations received by the Commission which may affect the "reputation or dignity or ... privacy" of the candidate are referred to the Chairperson; the candidate is notified and then has the option of responding in closed or open

IPPR Report, supra note 410 at 108; Justice Report, supra note 257 at 23-24.

Between 1989 and 1992, 35 of the appointees were women and 10 were persons of colour or Aboriginal, out of a total of 80: Touchstones for Change, supra note 150 at 188.

P.H. Russell, "Meech Lake and the Supreme Court" in K.E. Swinton \& C.J. Rogerson, eds., Competing Constitutional Visions: The Meech Lake Accord (Toronto: Carswell, 1988) 97 at 111; Zeigel, supra note 393 at 13-14.

"Assessing the Performance," supra note 322 at 42. 
session. ${ }^{453}$ The usual counter-argument to open hearings - that impressive candidates will not want to run the risk of public scrutiny - is unpersuasive both normatively and empirically. Judicial office is a democratic public good, not merely a private individual reward. Individual ego cannot be allowed to stymie community interests. Moreover, in South Africa, the dire predictions of an impoverished slate of second-rate candidates have not transpired. ${ }^{454}$ The public presentation advocated here would have primarily the same goals. The anticipated tenor of the proceeding is one in which the candidate is given an opportunity to put her or his best foot forward and to be open to questions, rather than an interrogation which could occur in a confirmation-style process. ${ }^{455}$ Further, delicate issues could be addressed in the three closed interviews and the final selection will also be confidential - in these areas, the need for honesty trumps the desirability of openness. ${ }^{46}$

Thirdly, greater transparency would increase accountability by virtue of the quality of appointments made. The public and commentators could continually assess the performance of the commission in diversifying the bench as they are being informed about the potential appointees before the appointment is formalized - in other words, before it is too late to do anything about it. Currently, so little is known about the appointment process that it would be a rare occurrence for the electorate to hold the executive accountable for its appointments to the bench. In contrast, opening up the process would allow for greater vigilance and participation by the public, and greater accountability for appointments made by the commission.

The final and crucial difference between the present processes and our proposed alternative is a continuing commitment and dedication to diversifying judicial appointments. Indeed, it has been shown that once a firm commitment to representativeness is pursued and implemented, added benefits ensue. An empirical study of appointments by the nominating committee in the United States under the Carter administration, which adopted clear affirmative action policies, has shown that the independence of the judiciary was increased by appointing more women and individuals from minority racial groups. Partisan political activity was largely associated with white male appointees, whereas less than half of female and Black appointees had a history of partisan activism. ${ }^{457}$ By appointing members of historically marginalized

453

454

$45 s$

Ibid. at 43.

Ibid. at 42.

McCormick reports that members of a judicial council who participated in interviewing processes "could recall cases when a candidate who looked good on paper fell down badly in an interview, and the reverse situation when a candidate who seemed rather marginal really 'grew up": "Judicial Councils," supra note 186 at 169. This has also been the experience of Devlin and MacKay in observing candidates for academic positions.

The proposal that the final selection meeting be closed differs from the appointment process of the South African Constitutional Court: "Assessing the Performance," supra note 322 at 44 . Our concern is that if the final selection meeting is public, the real debates and negotiations will take place elsewhere, with the consequence that the public hearing will be a mere formality. In this regard, we think that members of the Commission will be more engaged and more candid if the meeting is closed.

Baar, supra note 409 at 15 . 
groups, the quality of appointments increases, as does the heterogeneity of the bench. As Malleson has argued:

It has [been] demonstrated that secrecy is not a prerequisite of a judicial-appointments process and that public interviews can be conducted with dignity and restraint. It has [been] shown that appointments can be made which enrich the diversity of the Bench without significantly undermining its quality..... ${ }^{48}$

Thus, the pursuit of proportional representation in a responsible appointment process can both restrain partisanship and enhance professionalism. We will expand on the relationship between these three components of a democratic judiciary in the following section.

\section{CrIteria}

As indicated in Appendix II, there is now a fairly extensive list of job qualifications for being a judge, and we do not intend significantly to expand upon the lists which currently exist. There are variations from one jurisdiction to another, but there is also considerable overlap as to the essential qualifications for being a good judge. It is only recently that there has even been an effort to articulate criteria for being a judge, beyond that of being a member of a bar for a minimum number of years. This is a positive development on the road to a more qualified and diversified judiciary and is widely recognized as a vehicle for more equitable and diversified recruitment. However, there are certain observations which need to be highlighted. ${ }^{459}$

Of course, the setting of criteria is no guarantee of better results in terms of either the quality of the judges selected or their diversity. The appropriate job qualifications return us to our initial discussion of the role of the judge and the political dimensions of the job. There is also a need to examine whether the job qualifications are indeed vital to the performance of the job and are objective, rather than a means to exclude certain groups (intentional or otherwise). ${ }^{460}$ Consideration should also be given as to whether biases are embedded in apparently neutral criteria.

An example of the problem of possible adverse impact bias in spite of facially neutral criteria (and at least a partial solution) is provided by the work of the Ontario Judicial Appointments Advisory Committee, which emphasizes professional achievement, community awareness, and personality. While on its face community awareness and involvement appears to be neutral, it might have an adverse impact on women who may have less time than men to be involved in community organizations, because of the time-consuming demands of home and family. To the credit of the

458 "Assessing the Performance," supra note 322 at 49.

439 In assessing whether there is an equitable and non-discriminatory process, human rights commissions, equity officers, and others emphasize the importance of setting objective job related criteria.

460

This problem was discussed earlier in respect to the Supreme Court of Canada decision in BCGSEU, supra note 267. See also infra IV.B.1. 
Advisory Committee, it recognized the potential problem and elaborated on the community involvement criteria in the following terms:

With regard to community involvement and awareness, the committee recognizes that it would be unreasonable to insist on a high level of participation in community organizations for every candidate who is to be highly recommended. Often there are personal circumstances - for instance, major family responsibilities - which leave little time for volunteer work in the community. ${ }^{461}$

This elaboration did not go far enough for the National Association of Women and the Law, which made the following, more explicit recommendation for acknowledging the different situations of men and women in Canadian society:

Recommendation \#3: The evaluation criteria for the selection of judges should specify that childrearing, family activities, and household management are to be considered under "community awareness." $" 462$

It is important to recognize the different experiences of a historically marginalized group as an additional qualification for the job of judging, rather than merely to use that experience as a means of explaining the lack of a traditional qualification such as community involvement. The experiences of child rearing and managing a home may well be useful additional qualifications for the task of being a judge. Even the addition of specific criteria to take account of the different experiences of marginalized groups does not go far enough for some, who advocate a more thorough redrafting of the traditional criteria. ${ }^{463}$ In our view, the existing criteria may need to be both revised and expanded in order to produce a more diverse and pluralistic judiciary. One possibility may be to encourage the creation of a track for those who might seek parttime judicial appointments. ${ }^{464}$ Of course, both the nature of the problems and the potential solutions can also differ depending upon whether the issues relate to gender or race. These are the sorts of issues that commissions might discuss in their annual reports.

There are also a few statutory criteria that may need reconsideration. One is that statutes set the minimum years of experience at the bar as being five to ten years or transfer from another judicial post. While this may be a sensible restriction if one priorizes narrow professional experience over all other qualities, it does make the pool of non-traditional candidates (Aboriginals and other visible minorities) smaller, as they have generally graduated more recently. It is also interesting to note that two of the provinces that have a statutory minimum of five years practice at the bar, in reality

The (Ontario) Judicial Appointments Advisory Committee, Final Report and Recommendations (Toronto: 1992) at 39.

National Association of Women and the Law, Creating Diversity on the Bench, Submission to the Federal Department of Justice on Revising the Federal Judiciary Appointment Process, December, 1998, at 9 [unpublished].

J. Resnick, "On the Bias: Feminist Reconsiderations of the Aspirations for our Judges" (1988) 61 So. Cal. L.R. 1877 at 1922-23 argues that the criteria needs to be revised not just expanded.

Justice Report, supra note 257 at 19-20. 
require ten. ${ }^{465}$ Is the extra five years of experience a necessary qualification, given that it would tend to exclude non-traditional candidates from the pool? Again, commissions might be well-suited to making such an assessment and reporting accordingly.

Another statutory requirement at the federal level is a guarantee of Quebec representatives on the Supreme Court of Canada, the Federal Court, and the Tax Court. ${ }^{466}$ These provisions are a clear recognition of the relevance of identity, in this case regional/linguistic/cultural identity, to the role of judging. It could also be said that the guaranteed representation from Quebec is also an acknowledgement of the fact that it has a civil rather than a common law system; but this would have little relevance in the Federal Court and Tax Court where the judges do not deal with private law. Moreover, as we pointed out previously, most Supreme Court judges do not think that legal tradition and training has much impact upon their decision-making. Furthermore, the relevance of regional identity is also reflected in the practice of appointing three justices from Ontario, two from the West, and one from Atlantic Canada. On a similar kind of analysis, a good case could be made for statutorily entrenched Aboriginal representation as a matter of cultural or regional identity, and as representatives of a different system of law.

When we move from the statutory level to criteria established by policy and practice, there are further acknowledgements of the importance of demographics and other identity factors. Under the heading "Social Awareness," the federal policy in respect to s. 101 and s. 96 courts under the Constitution Act, 1867 includes a qualification of "sensitivity to gender and racial equality" and under "Professional Competence," "non mainstream legal experience." These criteria do not necessarily require a candidate to be a member of a historically marginalized group, but lawyers from such communities would likely be especially appropriate candidates on the basis of such criteria. The policy in British Columbia has a similar criterion - "appreciation for cultural diversity. ${ }^{3467}$

Further, under the heading "Demographics," Nova Scotia, Ontario, and Alberta expressly address at the policy criteria level, the importance of considering diversity as a factor in making judicial appointments. This section states:

British Columbia and Nova Scotia have a statutory requirement of five years but a practice of ten. Prince Edward Island has a statutory requirement of five years and the rest of the provinces and territories require ten years in the relevant statute, except for the Northwest Territories which requires seven years (see Appendix II). Tax Court Act, R.S.C. 1985, c. T-2, s. 4(4). See Appendix II.

467 It is also interesting to note that at the federal level, Nova Scotia, and Prince Edward Island include as a qualification "ability to exercise role conferred by Charter." This is a relatively clear recognition of a policy-making role. See Appendix 11 . 
The provincial judiciary should be reasonably representative of the population it serves. This requires overcoming the serious under-representation in the judicial complement of women, visible, cultural and racial minorities, and persons with a disability. ${ }^{468}$

In Nova Scotia, there is also a second branch to this demographics criteria: "it is essential for the provincial judiciary to reflect the bilingual nature of the province." Not surprisingly, bilingualism is also identified as a relevant criterion at the federal level and in New Brunswick. As an additional factor favouring persons with disabilities, Nova Scotia also qualifies the requirement that a judge have good health in the following way:

Good health except to the extent that any physical or mental disability would not reasonably preclude performance as a Judge. ${ }^{469}$

This summary of the detailed criteria for judicial appointments contained in Appendix II suggests that there is an emerging awareness of the value of diversity on the bench. However, the pattern across the country is still uneven, and the majority of the provinces and territories still make no reference to diversity as a positive job qualification. The policy in the Yukon Territory goes the greatest distance to recognizing links to a particular community as important and valid criteria for judicial appointments. It includes the following criteria:

- $\quad$ respect in the community;

- familiarity with Yukon First Nations issues;

- $\quad$ experience in northern communities;

- the need to have a bench that is demographically representative of the community. ${ }^{470}$

A clear statement of criteria for the appointment of judges is an important step towards escaping the old pattern of patronage appointments from within a wellconnected "old boys network." Much thought still needs to be given to revising and adding to these qualifications to take account of the policy-making role of judges in Canada and of the need for a more diverse judiciary. ${ }^{471} \mathrm{~A}$ further improvement in this evolution would be a more open process for developing criteria for judicial appointments, open to a wider range of inputs. This would be a part of the role of the judicial appointments commissions that we propose. At the same time, however, given the different functional needs and demographics of different jurisdictions, we do not expect uniformity across the country. The criteria need to be tailored to these different jurisdictions.

\footnotetext{
468 See Appendix II - Nova Scotia, Ontario, Alberta.

469 See Appendix II.

470 Territorial Court Act, R.S.Y.T. 1998, c. 26, s. 7. It is encouraging that these are found in the most recent statute on judicial appointments.

471 The added value of diversity in the judiciary is well articulated in The Honourable M. Omatsu, "The Fiction of Judicial Impartiality" (1997) 9 Can. J. Women \& L. 1.
} 
Finally, one criticism of the commission model is that the appointees of the commission will tend to be "conservative', 'orthodox', and 'unimaginative" and would therefore be antithetical to the goal of diversifying the bench to reflect society. ${ }^{472}$ Baar has termed this the "Ideology of Professionalism," which is a result of commissions looking strictly at the professional qualifications and experiences of candidates. ${ }^{473}$ However, once "merit" is redefined and statutorily entrenched in the manner we propose - to include representativeness as an integral part of judicial qualification - this can be easily resolved. The South African Judicial Services Commission interprets the constitutional provision of diversity in the following way:

Diversity ... is not an independent requirement, superimposed upon the constitutional requirement of competence; properly understood, it is a component of competence - the Court will not be competent to do justice unless, as a collegiate whole, it can relate fully to the experience of all who seek its protection. $^{44}$

Moreover, we have deliberately designed the composition of the commissions so that they can effectively value criteria beyond the dictates of a narrow professionalism.

\section{E. SUMMARY}

In sum, in terms of statutory status, composition, process and criteria, we believe that in the same way that partisan politics has required the critical supplement of professional criteria, professionalism itself needs to be supplemented by the democratic principle of proportionality. Our goal, in short, is a "triple P" judiciary, one that is politically accountable, professionally qualified, and proportionally representative. The primary roadblock to achieving such a system is the unwillingness of governments, especially the federal government, ${ }^{475}$ to surrender ultimate control over the judicial appointment process. This is undoubtedly a real political obstacle, but one that can be overcome if there is enough public support for an appointment commission option.

\section{Conclusion}

The contemporary alchemy of Canada is that of intense and intensifying diversity. As a country, we are engaged in a social experiment of vast proportions. Indeed, Canada is sometimes characterized as the first post-modern society. Yet, one of our most significant political institutions, the judiciary, remains significantly immune.

While we have expressed concerns at the outset about the dangers of an emergent judgocracy, we have not engaged in the interminable debate as to the relative merits of judges versus legislatures. For the purposes of this article, we have taken it as a given that judges exercise, and will continue to exercise, significant social and political

$472 \quad$ Winterton, supra note 395 at 208.

473 Baar, supra note 409 at 12-15.

474 As quoted in "Assessing the Performance," supra note 322 at 47.

475 B. Laghi \& K. Lunman, "Justice Minister defends process of nominating Supreme Court judges," The Globe \& Mail (26 February 1999) A4. 
power. Thus, we are engaged in a debate about the composition of a political elite. Our concern about the current system of judicial appointments is that, in terms of both processes and consequences, there are ongoing problems and profound gaps. Consequently, the result is an argument for democratic realignment at the institutional level rather than wide-scale democratic reconstruction. But we also resist the false dichotomy of reformism versus revolution. ${ }^{476}$ Institutional shifts can help engender larger democratic transitions. ${ }^{47} \mathrm{~A}$ changed elite can open up new spaces for democratic leverage. ${ }^{478}$

A series of reports from many provinces over the last fifteen years indicate that there are significant concerns about the effect of judges' decisions. ${ }^{479}$ These decisions are the output of the judicial system. One element of the input is the processes by which one becomes a judge. Our suggestions for improved procedures are enabling conditions that are also designed to increase the possibility of improved outputs. But, at the same time, we emphasize that we are in the realm of possibilities; we make no guarantees because in law, as in politics and as in life, there are no guarantees. Nor do we believe that a simple increase in numbers from historically disadvantaged groups is a sufficient change in judicial appointments practices because there are other powerful structural barriers. But, if increased numbers and reaching a critical mass is not adequate, it is at least a necessary precondition. A more flexible and open appointment process offers at least the promise of a more diverse bench, and, from such institutional change, there may flow a real change in the quality of justice in Canada.

Unger \& West, supra note 194 at 32, 58.

R.M. Unger, Social Theory: Its Situation and its Task (Cambridge: Cambridge University Press, 1987).

M. Smith, Lesbian and Gay Rights in Canada: Social Movements and Equality Seeking 1971-1995 (Toronto: University of Toronto Press, 1999).

See e.g. Nova Scotia, Royal Commission on the Donald Marshall, Jr., Prosecution, Report (Halifax: Royal Commission, 1989) and supra note 199. 


\section{APPENDIX I: JUDICIAL APPOINTMENT QUESTIONNAIRE}

A. RECRUITMENT: How does one apply to become a judge?

1. Invitation, application or nomination?

a) If invitation - from whom?

- What would give rise to an invitation?

b) If application- Could you include a copy of the application form?

- Where does one get it?

- To whom is it submitted?

- What other information is requested?

- What are the application instructions?

c) If nomination- who can nominate?

- What information must be given to make a nomination?

- Can the government nominate individuals and does this affect the process?

2. Is the vacancy advertised?

a) Where?

b) By whom?

c) Are specific groups targeted through advertising forums?

3. How important is word of mouth?

B. SCREENING PROCESS: How are the applicants evaluated?

1. Who decides the criteria and qualifications?

2. Is there a "job description"?

3. What are the criteria and qualifications?

4. Are there other criteria considered by convention which are not listed in government policy?

5. How is "merit" defined?

6. What are the required steps:

a) Curriculum vitae?

b) References? Formal or informal? How many? Can anyone act as a reference? 
c) Interview? Who conducts the interview? What questions are asked?

d) Investigation?

e) Consultation? Private or public? Who is consulted?

f) Others?

7. What is the evaluation system for the above steps?

8. Which of the steps in \#6 is most important?

9. Who conducts the process? Minister or AG or Committee?

10. How long are unsuccessful applications kept on file?

11. How often is reapplication necessary?

12. Is there a preference or pattern towards hiring re-applicants? Are they encouraged to reapply?

13. What is the duration of the whole process?

C. SELECTION: How is the successful applicant chosen?

1. Is there a short list?

2. Who shortlists and after which step in the process?

3. Who makes the final decision? MJ/AG, PM/Premier, Cabinet as a whole, Committee?

4. Is a confirmation of the decision required? (e.g. PM/Premier or GovGen/Lieutenant GG)

D. COMMITTEE: What is the role of the Committee?

1. Is the Committee a nominating body or a screening body?

2. What is the structure of the Committee?
a) Who sits?
b) How many seats?
c) How are members chosen (appointment or application)?
d) How often are they re-nominated?
e) Must the nominations be approved and by whom? 
f) How long do members sit?

3. What are the criteria for nominating a member to the committee?

4. Is the committee ad hoc, for set terms, or permanent?

5. What is the name, position and status of the Committee?

a) Other responsibilities besides appointments?

b) Is it part or independent of the executive?

6. What is the mandate and purpose of the Committee?

7. Representation of minority groups on the Committee?

8. Openness of the process: existence, publications, names of candidates or members...?

E. POLICY \& OBJECTIVES:

1. What are the policies, if any, regarding representation of disadvantaged groups?

2. What steps have been taken in practice towards implementing the policy?
a) systemic measures?
b) institutional/structural measures?
c) other policy initiatives?

3. What progress has been made?

4. Does it comply w/ the Federal Contractors Program and Employment Equity?

\section{F. STATISTICS:}

1. What is the total number of judges in each category?

2. Representation of groups in each category
a) gender
b) visible minority/race/colour/ethnic origin
c) aboriginal peoples
d) disability 

e) age
f) marital status
g) religion
h) sexual orientation
i) region
j) language

3. Are there discernible patterns of improvement over time?

4. Are there any other demographic categories not listed? 


\section{APPENDIX II: CRITERIA}

\section{Supreme Court of Canada}

Statutory Qualifications:

- Ten years at the bar of a province, superior court judge, or equivalent ${ }^{480}$

- Three of nine justices from Quebec ${ }^{481}$

Practice:

- Three justices from Ontario, two from the West, and one from Atlantic Canada

Federal Appointed Judges (other s. 101 and s. 96 courts, including the Nunavut Court of Justice)

Statutory Qualifications:

- Ten years at the bar of a province, superior court judge or equivalent ${ }^{482}$

- Four judges from Quebec on the Federal Court of Canada ${ }^{483}$

- Chief Justice or Associate Chief Justice of the Tax Court of Canada is to be from Quebec ${ }^{484}$

Policy:

Professional Competence and Experience

- proficiency in law

- well-rounded legal experience

- advocacy experience

- commitment to the law

- ability to exercise role conferred by Charter

- standards/reputation

- mature and objective judgment

- work habits

- writing and communication skills

- organizational skills including people and time management

- collegiality

- scholarly ability

- achievements and contributions including books and articles

- areas of specialization

482 Federal Court Act, supra note 466, s. 5(5); Tax Court of Canada Act, supra note 466, s. 4(3); Judges Act, R.S.C. 1985, c. J-1, s. 3. 
- non-mainstream legal experience

- bilingualism

\section{Personal Characteristics}

- ethical standards

- honesty

- integrity

- faimess

- tolerance

- patience

- common sense

- ability to listen

- ability to make decisions

- consideration for others

- courtesy

- tact

- humility

- reliability

- punctuality

\section{Social Awareness}

- sensitivity to gender and racial equality

- appreciation of social issues arising in litigation

- public and community service

- receptivity to ideas

\section{Potential Impediments to Appointment}

- drug or alcohol dependency

- civil or criminal actions

- health

- sexual harassment complaints

- professional complaints and/or disciplinary actions

- financial difficulties

- default of family support obligations

\section{Provincially Appointed Judges}

\section{British Columbia}

Statutory Qualifications: ${ }^{485}$

- Five years good standing with the Law Society of British Columbia or equivalent legal or judicial experience satisfactory to the Judicial Council 
Policy:

- normally ten years at the bar or a range of related experience

- legal reputation including

(a) reference from the Canadian Bar Association and judges before whom the applicant has appeared

(b) review of professional record from the Law Society of British Columbia

- general legal knowledge, preferably with recent practice in criminal, family and/or civil matters

- willingness to learn and a demonstrated commitment to ongoing professional education

- sensitivity to current dilemmas and issues facing the court and the judiciary

- ability to listen and communicate effectively

- personal characteristics such as decisiveness, even temperament, fairness, and common sense

- compassion for those coming before the court and an understanding of their circumstances

- respect in the community

- good health

- passion for the job

- handling of power

- adaptability - job changes and flexibility within the job

- humility

- appreciation for cultural diversity

- public service dedication

- ability to work with others cooperatively

- understanding of the role of the court in society

\section{Alberta}

Statutory Qualifications: ${ }^{486}$

- Canadian citizen

Policy:

Minimum Qualifications:

- Ten years good standing at the bar

- No criminal record

Professional Excellence 
- A high level of professional achievement in the area(s) of legal work in which one has been engaged. Experience in the field relevant to the division of the Provincial Court is desirable, but not essential

- Involvement in professional activities that keep one up to date with changes in the law and in the administration of justice

- An interest in, or some aptitude for, the administrative aspects of a judge's role

- Good writing and communication skills

\section{Community Awareness}

- A commitment to public service

- Awareness of, and an interest in, knowing more about the social problems that give rise to cases coming before the courts

- Interest in methods of dispute resolution, alternatives to formal adjudication, and in community resources available for participating in the disposition of cases

Personal Characteristics

- An ability to listen

- Respect for the essential dignity of all persons regardless of their circumstances

- Politeness and consideration for others

- Moral courage and high ethics

- An ability to make decisions on a timely basis

- Patience

- Punctuality and good regular work habits

- A reputation for integrity and fairness

- Compassion and empathy

- An absence of pomposity and authoritarian tendencies

\section{Demographics}

- The provincial judiciary should be reasonably representative of the population it serves. This requires overcoming the serious underrepresentation in the judicial complement of women, visible, cultural and racial minorities, and persons with a disability.

\section{Saskatchewan}

Statutory Qualifications: ${ }^{487}$

- ten years at the bar or related experience considered satisfactory to the Judicial Council 
Policy:

- a minimum level of educational achievement

- professional training and experience

- breadth of view and maturity

- tolerance, compassion, and sympathy

- understanding and knowledge of the democratic process

- capacity to grow and to develop intellectually and professionally

- age and health

- stability of character and judicial temperament

- wisdom and common sense

- ability to solve legal issues

- peer judgments

- community perception

\section{Manitoba}

Statutory Qualifications: ${ }^{488}$

- member in good standing of the Law Society of Manitoba

- entitled to practice as a barrister and solicitor in Manitoba

- has practiced as a barrister or solicitor in Manitoba for not less than five years or equivalent experience

Policy: There is no set policy as to the criteria used, but the committee usually accounts for the same qualities as set out under the federal appointments.

\section{Ontario}

Statutory Qualifications: ${ }^{489}$

- Ten years at the bar of one of the provinces or territories; or an aggregate of ten years at the bar and serving as a judge anywhere in Canada

Policy:

Professional Excellence

- a high level of professional achievement in the area(s) of legal work in which the candidate has been engaged. Experience in the field of law relevant to the division of the Provincial Court on which the applicant wishes to serve is desirable but not essential

- involvement in professional activities that keep one up to date with changes in the law and in the administration of justice 
VoL. 38(3) 2000

- interest in, or some aptitude for, the administrative aspects of a judge's role

- good writing and communications skills

Community Awareness

- a commitment to public service

- awareness of and an interest in knowing more about the social problems that give rise to cases coming before the courts

- sensitivity to changes in social values relating to criminal and family matters

- interest in methods of dispute resolution alternatives to formal adjudication and in community resources available for participating in the disposition of cases

\section{Personal Characteristics}

- an ability to listen

- respect for the essential dignity of all persons regardless of their circumstances

- politeness and consideration for others

- moral courage and high ethics

- ability to make decisions on a timely basis

- patience

- punctuality and good regular work habits

- a reputation for integrity and fairness

- compassion and empathy

- an absence of pomposity and authoritarian tendencies

\section{Demographics}

- The provincial judiciary should be reasonably representative of the population it serves. This requires overcoming the serious underrepresentation in the judicial complement of women, visible, cultural, and racial minorities, and persons with a disability.

\section{Quebec}

Statutory Qualifications:

- An advocate with ten years of practice $e^{490}$

- Degree of legal knowledge in the areas of law in which the judge will perform her or his duties, capacity for judgment, insight, ability for evaluation, sense of decision, concept of a judge's duty ${ }^{491}$

490 Courts of Justice Act, R.S.Q., c. T-16, 1977, s. 87, as am. by S.Q. 1988, c. 21, s. 30.

49) Regulation respecting the procedure for the selection of persons apt for appointment as judges, R.R.Q. 1981, c. T-16, r. 5, s. 18. 


\section{Nova Scotia}

Statutory Qualifications: ${ }^{492}$

- Barrister of the Supreme Court of at least five years standing

Policy:

\section{Minimum Qualifications}

- Ten years standing at the bar in a Canadian jurisdiction

\section{Personal Characteristics}

- respect for the essential dignity of all persons regardless of their circumstances

- a reputation for integrity and fairness

- politeness and consideration for others

- moral courage

- punctuality and good regular work habits

- good health except to the extent that any physical or mental disability would not reasonably preclude performance as a Judge

- not involved in serious, unresolved professional complaints, civil actions, or outstanding financial claims such as unpaid taxes or insolvency proceedings

- an absence of pomposity and authoritarian tendencies

Intellectual and Judgmental Ability

- fair and open-minded

- flexible (not unreasonably rigid)

- able to make decisions promptly or within a reasonable period of time

- patient and able to listen

Professional Excellence

- a high level of professional achievement in area(s) of legal work in which the candidate has been engaged. Experience in the field of law relevant to the Court on which the applicant wishes to serve is highly desirable.

- involvement in activities which keep one up to date with changes in the law and the administration of justice

- an interest in and some aptitude for administrative aspects of a judge's role

- good writing and communication skills 
Community Awareness and Understanding

- a commitment to public service

- awareness of and interest in knowing more about the social problems which give rise to cases coming before the courts

- sensitivity to changes in social values relating to criminal and family matters

- capacity to exercise role conferred upon the judiciary by the Canadian Charter of Rights and Freedoms

\section{Demographics}

- The provincial judiciary should be reasonably representative of the population it serves. This requires overcoming the serious underrepresentation of women and minorities. The Committee will recommend a well qualified person from an under-represented group if no one else is clearly better qualified.

- It is essential for the provincial judiciary to reflect the bilingual nature of the province.

\section{New Brunswick}

Statutory Qualifications: ${ }^{493}$

- A barrister or solicitor of the Court of Queen's Bench of New Brunswick and the Court of Appeal of New Brunswick and has been a member in good standing of the bar of a Province of Canada for at least ten years

Policy:

- high moral character

- human qualities: sympathy, generosity, charity, patience, maturity, objectivity

- proficiency in law

- relevant experience in the law

- intellectual and judgemental ability

- adherence to the ideal of public service

- good health and good work habits

- if bilingual, the level of second language competence

\section{Prince Edward Island}

Statutory Qualifications: ${ }^{494}$

- Membership in good standing with the Law Society

- Five years good standing at the bar of a province in Canada 
Policy:

\section{Personal Characteristics}

- essential dignity of all persons regardless of their circumstances

- a reputation for integrity and fairness

- politeness and consideration for others

- moral courage

- punctuality and good regular work habits

- good health

- an absence of involvement in serious, unresolved professional complaints, civil actions, or outstanding financial claims such as unpaid taxes

- an absence of pomposity and authoritarian tendencies

Intellectual and Judgmental Ability

- fairness and open-mindedness

- flexibility (not unnecessarily rigid)

- ability to make decisions promptly or within a reasonable period of time

- patience and ability to listen

\section{Professionalism}

- a high level of professional achievement in area(s) of legal work in which the candidate has been engaged. Experience in criminal law is highly desirable.

- involvement in activities which keep one up to date with changes in the law and in the administration of justice

- an interest and some aptitude for the administrative aspects of a judge's role

- good writing and communication skills

Community Awareness and Understanding

- a commitment to public service

- awareness of and interest in knowing more about the social problems which give rise to cases coming before the courts

- sensitivity to changes in social values relating to criminal matters

- capacity to exercise the larger policy role conferred upon the judiciary by the Canadian Charter of Rights and Freedoms

\section{Newfoundland}

Statutory Qualifications: ${ }^{495}$ 
- Ten years good standing at the bar or a province of Canada

- At the time of appointment, a practising member in good standing of the Law Society of Newfoundland

Considerations:

- There are no official guidelines, but the Council considers one's character, reputation, abilities, and reasons for wanting to become a judge.

\section{Northwest Territories}

Statutory Qualifications: ${ }^{496}$

- Canadian citizen

- Resides in the Territories

- Seven years good standing at the bar of the Territories or a province

- Professional excellence, community awareness, and personal characteristics

Policy: To be determined by the Committee within the next year.

\section{Yukon Territory}

Statutory Qualifications:497

- Member of the Law Society of Yukon

- Ten years practice or equivalent

Policy:

- ten years of practice or equivalent

- legal reputation

(a) review of professional record from the Law Society

(b) reference from the Canadian Bar Association and judges or decision makers before whom the applicant has appeared

- general knowledge of the law in criminal, family, and/or civil areas

- willingness to learn and a demonstrated commitment to ongoing professional education

- knowledge of and sensitivity to current issues facing courts and judiciary

- personal suitability

(a) even temperament

(b) fairness

(c) common sense

(d) compassion for and understanding of those coming before the bench

(e) maturity, life experience and wisdom

- ability to listen and communicate 
- respect in the community

- familiarity with Yukon First Nations issues

- experience in northern communities

- the need to have a Bench that is demographically representative of the community 


\section{APPENDIX III: CONTACTS}

The Honourable J.-L. Batiot, Chief Judge of the Nova Scotia Provincial Court

The Honourable Justice Beverley A. Browne, Senior Judge of the Nunavut Court of Justice

Heather Cooper, Assistant Deputy Attorney General of Ontario, Court Services Division

Brenda Croft, Secretary to the Nova Scotia Advisory Committee on Provincial Judicial Appointments

Cynthia Davis, Director, Research and Planning, New Brunswick Justice Department

The Honourable C.A. Dumas, Chief Judge of the Provincial Court of New Brunswick

Karen Fulham, Executive Assistant to the Chief Judge of the Provincial Court of Manitoba

Deborah Gillespie, Office Manager, Legal and Judicial Services Division, Department of Community Services and Attorney General, Prince Edward Island

The Honourable Robert W. Halifax, Chief Judge of the Northwest Territories Territorial Court

Susan Hardy, Department of Justice, Nunavut Territory

Ann Kelly, Administrator/Recording Secretary, Ontario Judicial Appointments Advisory Committee

Pierre Legendre, Attorney Chief of the Deputy Minister's Staff, Quebec

The Honourable D.S. Luther, Chief Judge of the Provincial Court of Newfoundland

Andre S. Millar, Judicial Appointments Secretary, Office of the Commissioner for Federal Judicial Affairs, Ottawa

Tim Nicholls, Court Services, Alberta Justice

Denise E. Paluck, Legal Officer, Office of the Chief Judge of the Provincial Court of British Columbia

Marlene Rodie, Secretary to the Judicial Council of Saskatchewan

Mike E. Smith, Director of Judicial Administration, British Columbia

The Honourable Barry Stuart, Chief Judge of the Territorial Court of Yukon 
The Honourable Ralph C. Thompson, Chief Judge of the Provincial Court of Prince Edward Island

The Honourable Ernest J. M. Walter, Chief Judge of the Provincial Court of Alberta Stuart Whitley, Q.C., Deputy Minister, Yukon Justice 


\section{Appendix IV: Bibliography of Judicial AppoIntment Reform Proposals}

British North America Act, 1867 (U.K.), 30 \& 31 Victoria, c. 3.

J.A. Clark, "Appointments to the Bench" (1952) 30 Can. Bar. Rev. 28.

Antonio Perrault, "La Cour suprême du Canada" [January 1953] Relations 18.

Quebec, Report of the Royal Commission of Inquiry on Constitutional Problems, v. 1-5, (Quebec: Province of Quebec, 1956).

P.J.T. O'Hearn, Peace, Order and Good Government: A New Constitution for Canada (Toronto: Macmillan Company of Canada, 1964).

A.S. Abel, "The Role of the Supreme Court in Private Law Cases" (1965) 4 Alta. L. Rev. 39.

J.-Y. Morin, “A Constitutional Court for Canada” (1965) 43 Can. Bar. Rev. 545.

M. Faribault \& R.M. Fowler, Ten to One: The Confederation Wager (Toronto: McClelland and Stewart, 1965).

"A Symposium on the Appointment, Discipline and Removal of Judges: The Annual Meeting of the Canadian Bar Association, Banff, Alberta, August 30, 1971" (1973) 11 Alta. L. Rev. 279 at 285-87 (Remarks of G.M. Stirling, Q.C.). See also The 1966 Yearbook of the Canadian Bar Association and the Minutes of Proceedings of its FortyEighth Annual Meeting (Ottawa: National Printers, 1966) at 120-31.

E.A. Tollefson, "The System of Judicial Appointments: A Collateral Issue" (1971) 21 U.T.L.J. 162.

W.H. Hurlburt, Q.C., “Appointment of Judges” (1968) 6 Alta. L. Rev. 175.

P.H. Russell, "The Jurisdiction of the Supreme Court of Canada: Present Policies and a Programme for Reform" (1968) 6 Osgoode Hall L.J. 1.

P.H. Russell, "Constitutional Reform of the Canadian Judiciary" (1969) 7 Alta. L. Rev. 103.

P.E. Trudeau, The Constitution and the People of Canada (Ottawa: Government of Canada, 1969).

W.R. Lederman, "Thoughts on Reform of the Supreme Court of Canada" (1970) 8 Alta. L. Rev. 1.

Canada, "Victoria Charter" in H.F. Davis, The Constitutional Review 1968-1971: Secretary's Report (Ottawa: Canadian Intergovernmental Conference Secretariat, 1974) at 373. 
Canada, Final Report of the Special Joint Committee of the Senate and of the House of Commons on the Constitution of Canada (Ottawa: Queen's Printer, 1972) (Co-chairs: G.L. Molgat \& M. MacGuigan).

Canadian Bar Association Committee, Report: The Appointment of Judges in Canada (Ottawa: The Canadian Bar Foundation, 1985).

H.W. Silverman, "On Judicial Appointments" (1975) 23 Chitty's L.J. 35; H.W. Silverman, "Reform of Judicial Selection and Appointment" (1976) 24 Chitty's L.J. 179.

Bill C-60, The Constitutional Amendment Act, 1997.

Alberta, Harmony in Diversity: a New Federalism for Canada - Alberta Government Position Paper on Constitutional Change (Edmonton: Government of Alberta, 1978).

British Columbia, "Reform of the Supreme Court of Canada: Paper No. 4" in British Columbia's Constitutional Proposals: Presented to the First Ministers ' Conference on the Constitution (Ottawa: Province of British Columbia, 1978) at 43.

Committee on the Constitution, The Canadian Bar Association, Towards a New Canada (Montreal: Canadian Bar Foundation, 1978).

W.R. Lederman, "Current Proposals for Reform of the Supreme Court of Canada" (1979) 57 Can. Bar. Rev. 687.

Northwest Territories, The Justice House: Report of the Special Advisor on Gender Equality to the Minister of Justice of the Northwest Territories (Yellowknife: Government of the Northwest Territories, 1992).

Canada, The Task Force on Canadian Unity, A Future Together: Observations and Recommendations (Quebec: Minister of Supply and Services Canada, 1979).

The Constitutional Committee of the Quebec Liberal Party, A New Canadian Federation (Montreal: Quebec Liberal Party, 1980).

Constitution Act, 1982, being Schedule B to the Canada Act 1982 (U.K.), 1982, c.11.

A.W. MacKay \& R.W. Bauman, "The Supreme Court of Canada: Reform Implications for an Emerging National Institution" in C. Beckton \& A.W. MacKay, eds., The Courts and the Charter (Toronto: University of Toronto Press, 1985).

Canadian Bar Association Committee, Report: The Appointment of Judges in Canada (Ottawa: The Canadian Bar Foundation, 1985).

Special Committee on the Appointment of Judges, Judicial selection in Canada: discussion papers and reports (Toronto: Canadian Association of Law Teachers, 1987). 
W.R. Lederman, "Constitutional Procedure and the Reform of the Supreme Court of Canada" (1985) 26 C. de D. 195.

Canada, A Guide to the Meech Lake Constitutional Accord (Ottawa: Government of Canada, 1987); P.W. Hogg, Meech Lake Constitutional Accord Annotated (Toronto: Carswell, 1988).

Canada, Department of Justice, A New Judicial Appointments Process (Ottawa: Minister of Supply and Services Canada, 1988).

Manitoba Law Reform Commission, Report on The Independence of Provincial Court Judges (Winnipeg: Queen's Printer, 1989).

P. McCormick \& I. Greene, Judges and Judging (Toronto: James Lorimer \& Company, 1990).

D.M. Beatty, Talking Heads and the Supremes: The Canadian Production of Constitutional Review (Toronto: Carswell, 1990) at 257-71.

I. Grant \& L. Smith, "Gender Representation in the Canadian Judiciary" in Appointing Judges: Philosophy, Politics and Practice (Toronto: Ontario Law Reform Commission, 1991) at 57.

J. Smith, "Executive Appointment of the Judiciary: A Reconsideration" in Appointing Judges: Philosophy, Politics and Practice (Toronto: Ontario Law Reform Commission, 1991) at 189.

Canada, Responsive Institutions for a Modern Canada (Ottawa: Minister of Supply and Services Canada, 1991); Canada, A Practical Guide to the Constitutional Agreement (Aylmer, Quebec: Dialogue Canada, 1992).

Northwest Territories, The Justice House: Report of the Special Advisor on Gender Equality to the Minister of Justice of the Northwest Territories (Yellowknife: Government of the Northwest Territories, 1992).

A. Keller, "Guarding the Guardians: Pressures for Reform to the Supreme Court Nominations Process" (1994) 25 R.G.D. 283.

J.S. Ziegel, "Appointments to the Supreme Court of Canada" (1994) 5 Const. Forum 10.

M.L. Friedland, A Place Apart: Judicial Independence and Accountability in Canada (Ottawa: Canadian Judicial Council, 1995). 